\title{
Decontamination Processes for Restorative Operations and as a Precursor to Decommissioning: A Literature Review
}

Prepared by J. L. Nelson, J."R. Divine

Pacific Northwest Laboratory

Operated by

Battelle Memorial Institute

Prepared for

U.S. Nuclear Regulatory .

Commission 


\section{NOTICE}

This report was prepared as an account of work sponsored by an agency of the United States Government. Neither the United States Government nor any agency thereof, or any of their employees, makes any warranty, expressed or implied, or assumes any legal liability or responsibility for any third party's use, or the results of such use, of any information, apparatus product or process disclosed in this report, or represents that its use by such third party would not infringe privately owned rights.

U. S. Nuclear Regulatory Conmission Washington, D. C. 20555

Printed copy price: $\$ 5.50$

and 


\section{Decontamination Processes for Restorative Operations and as a Precursor to Decommissioning: A Literature Review}

Manuscript Completed: April 1981

Date Published: May 1981

Prepared by

J. L. Nelson, J. R. Divine

Pacific Northwest Laboratory

Richland, WA 99352

\section{Prepared for}

Division of Engineering Technology Office of Nuclear Regulatory Research U.S. Nuclear Regulatory Commission Washington, D.C. 20555

NRC FIN B2303 


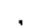

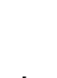




\section{ACKNOWLEDGMENTS}

The project discussed in this document was cosponsored by the Systems Performance Branch and Chemical Engineering Branch of the U.S. Nuclear Regulatory Commission (NRC). The authors gratefully acknowledge the comments and additional input received from the following Pacific Northwest Laboratory (PNL) staff: L. D. Perrigo, G. A. Halseth, G. R. Hoenes, L. F. Munson, R. L Dillon, and L. G. Faust. 


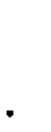

. 


\section{ABSTRACT}

Pacific Northwest Laboratory (PNL) conducted an comprehensive literature review of actual reactor decontamination processes that are currently available. In general, any decontamination process should be based on the following criteria: effectiveness, efficiency, safety, and waste production. The information that was collected and analyzed has been divided into three major categories of decontamination: chemical, mechanical, and electrochemical. Chemical methods can be further classified as either low-concentration, singlestep processes or high-concentration, single- or multistep processes. Numerous chemical decontamination methods are detailed. Mechanical decontamination methods are usually restricted to the removal of a contaminated surface layer, which limits their versatility; several mechanical decontamination methods are described. Electrochemical decontamination is both fast and easily controlled, and numerous processes that have been used in industry for many years are discussed. Information obtained from this work is tabulated in Appendix A for easy access, and a bibliography and a glossary have been provided. 



\section{SUMMARY}

There is an increasing realization by the public and the nuclear industry that decontamination of nuclear facilities is necessary for both continued operations and decommissioning. Processes used as a precursor to decomissioning may include more destructive measures than allawable for facilities that will be restored to operation; however, they are expected to have the potential for a greater degree of decontamination.

This report is the result of a comprehensive literature review wherein the authors have collected and analyzed information on actual decontamination processes that are currently available. Processes that are acceptable for the primary system are reviewed, as are those that are acceptable for interior structural members (such as concrete or painted surfaces) and for exterior locations (such as concrete or soil). Applicability is based on such factors as extent of decontamination, corrosiveness, waste produced, and time required for application. Decontamination of activated materials such as fuel-cladding and bio-shield components is beyond the scope of this program except for possible removal of loose surface deposits.

.The information presented in this report is also tabulated in Appendix A for easy access. The information has been divided into three major groups: chemical decontamination methods, mechanical decontamination methods, and electrochemical decontamination methods.

Chemical methods are further subdivided into low-concentration, singlestep processes and high-concentration, single- or multistep processes. Within these classifications the chemical processes can be surmarized into six groups:

- high pH oxidation and dissolution

- high pH oxidation followed by low pH dissolution

- low pH oxidation and dissolution

- low pH oxidation followed by low pH dissolution

- low pH dissolution

- low pH reduction and dissolution. 
Mechanical decontamination methods usually involve the removal of a relatively thick surface layer and as such are generally less versatile than chemical methods. They are restricted to exposed surfaces that are accessible from some exterior point. Probably the best-known mechanical methods involve pneumatic spalling of contaminated concrete surfaces and grit blasting of steam generator surfaces.

Electrochemical processes have the advantage of being fast, readily controllable, and effective; however, it is generally necessary to have the secondary electrode in the immediate vicinity of the area being cleaned. The best-known electrochemical process is electropolishing, which is used to remove the outer surface of a metal object.

The recent increased emphasis on decontamination has prompted the U.S. Nuclear Regulatory Commission (NRC) to sponsor projects that will fill some of the information gaps for currently existing processes. This document, its future supplements, and the complementary laboratory program will provide sufficient information to make reasonable selections for decontamination processes for any given reactor. 


\section{CONTENTS}

AKNOWLEDGMENTS .

ABSTRACT .

SUMMARY

INTRODUCTION

BACKGROUND

METHODOLOGY

Literature Survey

Laboratory Notebooks

Discussions

REVIEW OF DECONTAMINATION AND CHEMICAL CLEANING METHODS $\quad \cdot \quad \cdot \quad \cdot \quad 9$

SYSTEM CHARACTERISTICS $\quad \cdot \quad \cdot \quad \cdot \quad \cdot \quad \cdot \quad \cdot \quad \cdot \quad \cdot \quad \cdot \quad 10$

BWR and PWR System Characteristics . . . . . . 11

Other Systems . . . . . . . . . . . . . 13

CHEMICAL DECONTAMINATION METHODS

High-Concentration Processes . . . . . . . . 16

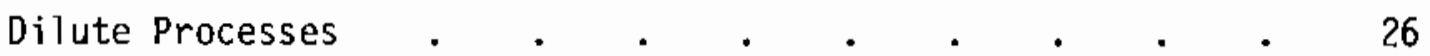

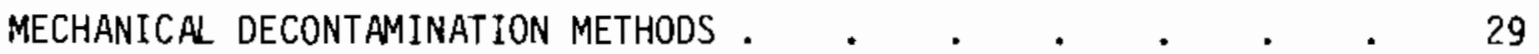

ELECTROCHEMICAL DECONTAMINATION METHODS . . . . . . . 45

RADIOACTIVE WASTE DECONTAMINATION

PROCESS REVIEW •

CHEMICAL DECONTAMINATION PROCESSES . . . . . . . . . 60

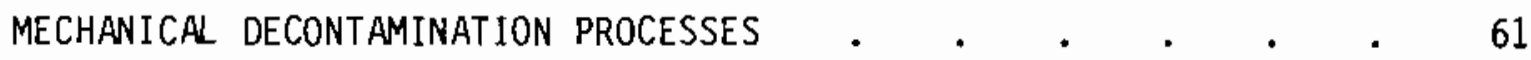

ELECTROCHEMICAL DECONTAMINATION PROCESSES • • • . . . . . 62

OPERATIONAL DATA 


\begin{tabular}{|c|c|c|c|c|c|c|c|c|c|c|}
\hline CURRENT & STATUS OF & DECONT & AMINA & TION & N PRC & SSES & & - & . & \\
\hline REFERENCES & . & - & - & . & . & . & & . & - & - \\
\hline BIBL IOGRAPHY & . & . & . & . & . & . & & . & - & - \\
\hline APPENDIX A - & OECONTAMII & NATION & METHO & & (TABL & & & . & . & . \\
\hline APPENDIX B - & GLOSSARY & OF TERM & & . & . & . & & . & . & . \\
\hline
\end{tabular}




\section{FIGURES}

1. Options for Handling Contaminated Reactors . . . . . . . 3

2. Simplified Djagram of a Pressurized Water Reactor (PWR) . . . . 12

3. Simplified Diagram of a Boiling Water Reactor (BWR) . . . . . 14

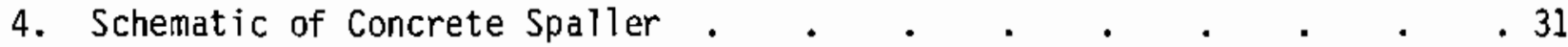

5. Schematic of the Type of Electropolishing Cell Used to
Decontaminate Metal Surfaces . . . . . . . . 47

6. Relationship of Current Density and Cell Voltage for Electropolishing Showing Optimum Operating Region for

Electrochemical Decontamination $\quad . \quad$. $\quad . \quad$. $\quad . \quad$. . . 48

7. Trench Decontamination by Electrodialysis $\quad . \quad$. $\quad . \quad$. $\quad . \quad$. 51

\section{$\underline{\text { TABLES }}$}

1. Key Word List . . . . . . . . . . . . . 5

2. Conditions Evaluated and Results Obtained on Stainless Steel with Modified Alkaline Permanganate-Ammonium Citrate

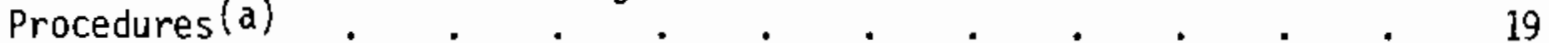

3. Effect of Velocity on the Decontamination Factor Achieved with the Alkaline Permanganate-Ammonium Citrate Procedure . . . . 20

4. Decontamination of Different Surfaces With a Single Application

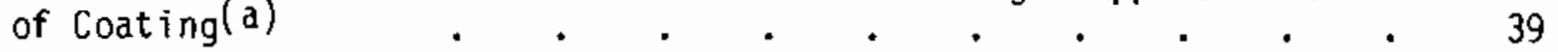

5. Metal Cleaning Salt Baths . . . . . . . . . . . 50 
.

. 


\section{INTRODUCTION}

The need for reactor decontamination and suitable decontamination processes has been recognized for many years. This need was universally accepted until the late 1960s when, at least in the United States, industry took the position that radiation levels were not increasing and that decontamination problems were under control. Toward the mid-1970s regulatory agencies and industry began to express renewed concern about radiation and the environment, and the interest in decontamination again began to grow. Today, there is interest in decontaminating not only operating facilities but also facilities that are scheduled for decommissioning.

With this in mind, the Division of Safeguards, Fuel Cycie, and Environmental Research of the U.S. Nuclear Regulatory Commission (NRC) and the Division of Engineering (NRC) requested that Pacific Northwest Laboratory $(P N L){ }^{(a)}$ examine the options available for decontamination for continued operations and for decormissioning.

A large number of suitable or potentially suitable processes for reactor decontamination were examined. Processes were reviewed that are acceptable for both the primary system and the containment system structural members (such as concrete or painted surfaces) and for exterior locations (such as concrete and soil). Because this study was also directed towards decommissioning work, many processes were examined that may have higher corrosion rates than normally considered acceptable for continued operation but that may provide improved decontamination.

This report discusses only the actual physical and chemical decontamination processes available. It is true, however, that a successful decontamination is not solely dependent on the decontamination process because other factors (such as plant design, planning, procedures, training, and management) may be equally or more important. The role of these other factors will be developed in future reports from this program.

(a) Operated for the U.S. Department of Energy (DOE) by Battelle Memorial Institute. 
In addition to performing a literature search and preparing a bibliography, we have also attempted a literature review wherein information has been collected and analyzed. The information is tabulated in Appendix A.

\section{BACXGROUNO}

Early in the history of radiochemistry and reactor technology decontamination was not considered because of the lack of radiation detection instruments and a poor understanding of radiation effects. However, the effects of exposures to high radiation fields soon became understood; and improved radiation detectors permitted easy radiation monitoring. Today, the public and the nuclear industry are more concerned about radiation effects than ever before. At the same time, instrumentation permits detection of low levels of radioactivity on surfaces that may appear clean.

In the fifties and early sixties the need for reactor decontamination was clear cut, and reactor designs (for example, Dresden-1) included decontamination features. During this time considerable effort was expended on decontamination research and development (R\&D) both in the United States and abroad (Ayres 1970). In the late sixties there was a rather abrupt loss of interest in decontamination. Worden (1980) attributes this to the emphasis on growth in the nuclear industry; however, it should be observed that radiation levels appeared to be leveling off in various operating plants. Thus, with radiation levels "under control" the need for new decontamination effort ceased in the United States. Interestingly, other countries did not stop their work. Canada, for example, continued its efforts, which led to the CAN-DECON lowconcentration process. Towards the mid-1970s an interest in decontanination was rekindled in the United States. This was due in part, such as in the case of Dresden-1, to the realization that exposure rates were increasing and that critical component inspection and maintenance was scheduled (Worden 1980). In addition, decommissioning requirements influenced the interest in decontamination.

As shown in Figure 1, decontamination is an important operational step in the options open for decommissioning. One process that will not be discussed 


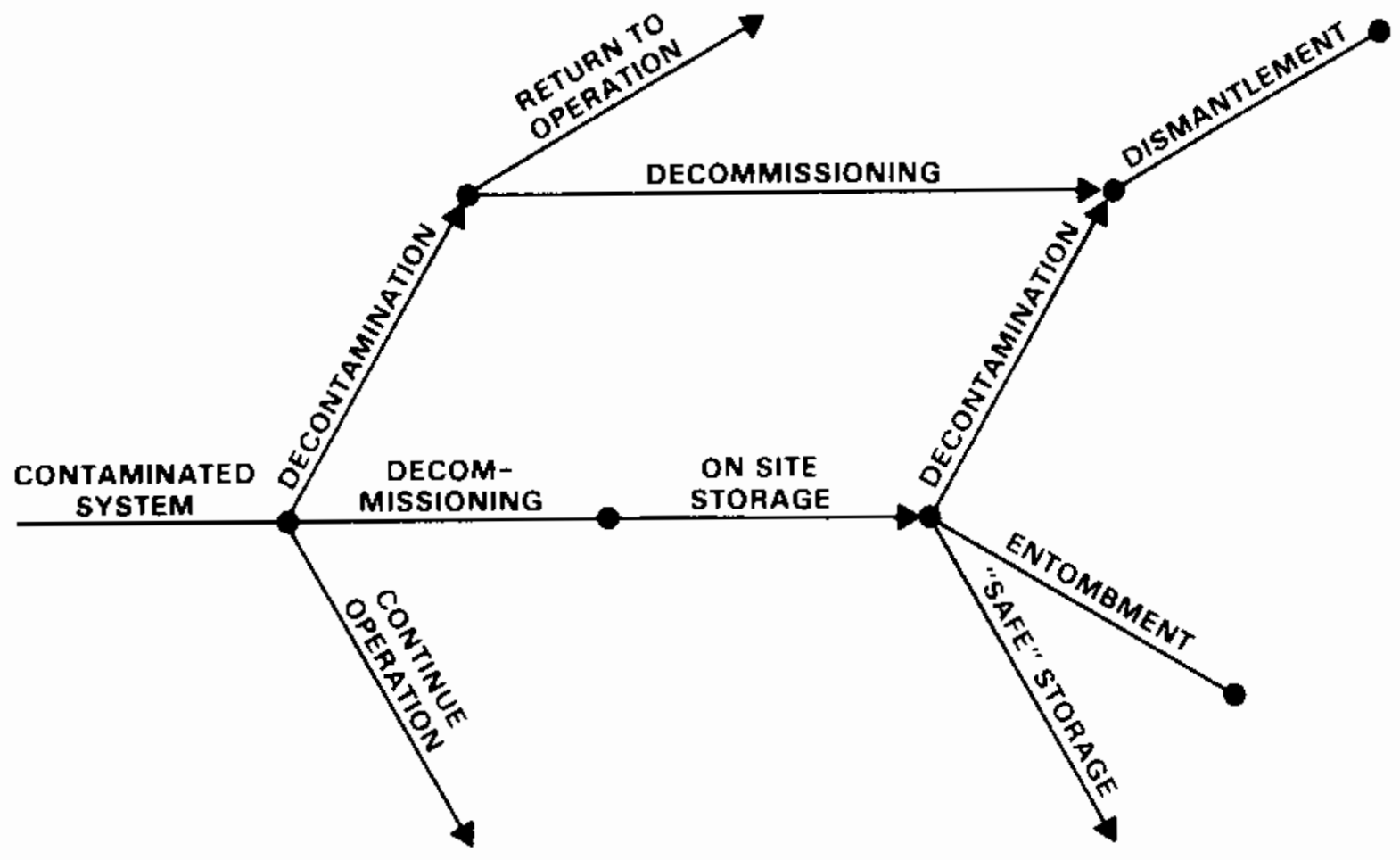

FIGURE 1. Options for Handling Contaminated Reactors

in this report is the use of natural decay time in lieu of active decontamination (shown in Figure 1 as "Safe Storage").

Several factors of decomissioning led to the accelerated interest in decontamination, including increased numbers of facilities to be decomissioned and possible recovery of construction materials. There are currently over 60 shutdown reactor facilities, although many are quite small (Erickson 1979) and not all will require decontamination before dismantiing. A large push in decomissioning and presumably decontamination is expected in the next 20 years, especially internationally; France alone expects to decommission 80 nuclear installations by the year 2000 (Manion 1979). Such a large number of facilities may provide an important source of construction materials. Manion states that thousands of tons of potentially recoverable metals are present in a single reactor. 


\section{METHODOLOGY}

At the beginning of this program, three major methods of obtaining information were considered: manual and computerized searches of the literature, review of old Hanford notebooks, and discussions with Hanford and other personnel. The purpose of this three-fold approach was to characterize decontamination processes that are in use, that may have been tested and rejected in the past, or that are currently under development. Each of these sources provides unique contributions to the technology. In looking at currently available processes, we have limited ourselves to U.S. publications; but some interaction from foreign experience is expected. Previously rejected processes were reviewed because for this report decontamination was being considered as a precursor to decommissioning as well as to further operation. A process may have been rejected in the past because of unacceptable corrosion rates; however, for decommissioning purposes, we need to know what these rates are, not just that they were too high for a system being returned to service. Finally, new processes, even if proprietary factors prevent a discussion in the report, provide an insight that may suggest application or modification of other nonproprietary processes.

\section{Literature Survey}

Various abstracts and abstract services (including the Decontamination and Decommissioning data base, Nuclear Science Abstracts, and Environmental Aspects of the Transuranics data base) were used in the computerized search to collect potential tities for review. Table 1 shows the key word list that was generated for the search, which produced well over a quarter of a million citations. The number of citations was reduced about 10\% by grouping (which eliminated some duplication) into the categories shown in Table 1. By combining Group 1-decontamination and decommissioning (D\&D) terms--with each of the other groups, the total number of citations was reduced to about 2500 .

The title, abstract, and key words associated with each title were then examined; and oniy papers dealing with decontamination and cleaning processes were considered. Other literature references found with key words such as cost or exposure were reviewed to provide input to other tasks in the program 
TABLE 1. Key Word List

\begin{tabular}{|c|c|c|}
\hline D\&D Terms: & $\begin{array}{l}\text { Decontamination } \\
\text { Decommissioning } \\
\text { Reactor Decommissioning }\end{array}$ & $\begin{array}{l}\text { Demolition } \\
\text { Reactor Dismantling } \\
\text { Fuel Assembly Dismantling }\end{array}$ \\
\hline Materials: & $\begin{array}{l}\text { Pipes } \\
\text { Concretes } \\
\text { Cements } \\
\text { Paints }\end{array}$ & $\begin{array}{l}\text { Soils } \\
\text { Coatings } \\
\text { Films } \\
\text { Asphalts }\end{array}$ \\
\hline Methods: & $\begin{array}{l}\text { Electrochemical Coating } \\
\text { Chemical Coating } \\
\text { Evaporation } \\
\text { Solidification } \\
\text { Inorganic Acids }\end{array}$ & $\begin{array}{l}\text { Surface Coating } \\
\text { Electrochemistry } \\
\text { Abrasion } \\
\text { Abrasives }\end{array}$ \\
\hline $\begin{array}{l}\text { Contaminants } \\
\text { and Wastes: }\end{array}$ & $\begin{array}{l}\text { Fission Products } \\
\text { Spent Fuels } \\
\text { Transuranic Elements } \\
\text { Transuranic Compounds } \\
\text { Actinides } \\
\text { Low-Level Radioactive } \\
\text { Wastes } \\
\text { High-Level Radioactive } \\
\text { Wastes }\end{array}$ & $\begin{array}{l}\text { Liquid Wastes } \\
\text { Solid Wastes } \\
\text { Gaseous Wastes } \\
\text { Waste Disposal } \\
\text { Waste Storage } \\
\text { Waste Processing }\end{array}$ \\
\hline Exposure: & $\begin{array}{l}\text { Radiation Doses } \\
\text { Dose Rates } \\
\text { Radiation Effects } \\
\text { Environmental Effects } \\
\text { Environmental Impacts }\end{array}$ & $\begin{array}{l}\text { Environment } \\
\text { Surface Contamination } \\
\text { Radioactivity } \\
\text { Radionuclide Kinetics }\end{array}$ \\
\hline Reactors: & $\begin{array}{l}\text { Pressurized Water Reactors } \\
\text { Boiling Water Reactors } \\
\text { Light Water Gas Reactors }\end{array}$ & \\
\hline Cost: & $\begin{array}{l}\text { Cost/Benefit Analysis } \\
\text { Economics }\end{array}$ & \\
\hline
\end{tabular}

and a broader background to the process review task and because there was a slight chance one would actually discuss a specific process rather than comment on the need.

A computerized search provides a very rapid means of scanning compilations of comercial (including government) abstract services. It does not necessarily provide an all-inclusive search because: 
- Most computerized services provide comprehensive coverage only back to about 1970 .

- Publication may have been in an "obscure" journal (that is, a journal not abstracted by the service or one not normaliy used for the particular subject).

- The selection of key words, combinations of key words, or other reasons may lead to inadvertent rejection of te particular citation. (a)

Because of these possible omissions, a limited manual search was made; and the major, and expected, finding was that most of the older documents (such as from Hanford, Oak Ridge, and the numerous other laboratories doing decontamination work) were not listed. It was also found, however, that many of the older documents are no longer in existence, except perhaps in personal files. Laboratory Notebooks

It was proposed that retired Hanford laboratory notebooks be used as a source of otherwise inaccessible information on decontamination. In view of the large number of programs and the extensive effort placed on decontamination, these notebooks were expected to be a wealth of data. However, for the most pertinent dates (prior to the late 1960s) no records were kept of who was assigned to specific books. The only records found for these dates have been in personal files that were not always complete because they often reference other logbooks that are frequently inaccessible. In addition, most of the process information in the old documents and logbooks is available, in at least sumary form, in either Ayres (1970) or Weed (1962).

(a) Probably the most noteworthy example of such an omission is that of J. A. Ayres' book Decontamination of Nuclear Reactors and Equipment, which for some reason was not included in any of the computer listings. 


\section{Discussions}

Discussions with persons knowledgeable in the decontamination field and particularly ones currently working in the area were largely limited to indications of the direction in which decontamination R\&D is moving; few specific details could be obtained. Typically, the researcher was either willing to discuss a new process in detail only on a proprietary basis or was not willing to discuss the program except in a general fashion.

The overall result of the limitations noted is that this report deals almost exclusively with published data. However, based on discussions with other experienced coworkers on areas of concern with respect to certain decontamination chemicals and other background information, it was possible to provide the comprehensive review of possible decontamination processes presented in this report. 


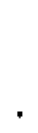




\section{REVIEW OF DECONTAMINATION AND CHEMICAL CLEANING METHODS}

Decontamination and cieaning are distinguished in this search as separate processes even though they can be the same procedure. As pointed out by Ayres (1970) the difference is a matter of degree of cleaning and the emphasis on species removed. Both processes are considered because cleaning, being a broader subject, can bring in a fresh viewpoint for decontamination needs.

Decontamination is defined as the general removal of superficial dirt and oxides from surfaces; cleaning refers to the removal of nonradioactive materials. Decontamination should be considered to be a part of cleaning because, in general, only a small fraction of the material removed during decontamination is radioactive. Ayres (1970) suggests that it is possible to distinguish between the two processes by the degree of cleaning. Cleaning is considered complete when $99 \%$ of the crud is removed or basically when it is no longer visible or when some other condition returns to "normal" (for example, when heat transfer in a heat exchanger returns to original startup values). Decontamination in contrast requires a 10 - or 100-fold improvement in the degree of cieaning because of the ready detection of radioactivity.

In actual practice, decontamination is considered complete when it meets the ALARA criterion (As Low As Reasonably Achievable) for the task. Thus, reducing the original amount of radioactivity to $1 \%$ of its original value may reduce the attendant exposure rate enough to allow maintenance. On the other hand, to release an item to unrestricted use by the public will require a much more thorough decontamination and the lower limit may be set by the background radiation limit and the particular type of radioactivity--alpha, beta, or garma.

Effective chemical cleaning is truly a multidisciplinary field. To devise a given process and apply it effectively requires an understanding of:

- the chemistry of the base material, the contaminant, and the cleaning solution

- the kinetics of removal (rates of dissolution and mass transport)

- the behavior of the contaminant after it is removed. 
How these elements of the cleaning process behave as a function of temperature, changes in construction materials, flow rate, radiation fields, and time determines whether cleaning occurs and whether the radioactivity can be removed or whether it redeposits.

Although some reagents and processes frequently used in cleaning are capable of yielding satisfactory decontamination factors (DFs), they are not considered useful in decontamination work because they are too corrosive or contain chemicals unacceptable for use in reactor systems. For example, chioride and fluoride are especially corrosive to stainless steel and Zircaloy components, respectively; and sulfides are ordinarily to be avoided when Inconel is present. If safety during the decomissioning process is not compromised, higher corrosion rates are acceptable in the case of decontamination for decommissioning because the equipment will be either disposed of or salvaged for its component materials.

In this section, the various reactor areas that require decontamination are discussed. Decontamination methods are tabulated by basic type--chemical, mechanical, or electrochemical--and then by the type of material being reviewed. General characteristics of the processes and some detailed data are presented, and general limitations of each type of process are discussed. Some inf ormation is also presented on the purification of various process streams resulting from decontamination so that a waste volume reduction option may be considered.

\section{SYSTEM CHARACTERISTICS}

The term reactor decontamination of ten implies decontamination of on $7 y$ the primary system. Although this viewpoint is very narrow and incorrect from the standpoint of decomissioning, it may be somewhat justified because the primary system is a major source of radiation exposure associated with power production. Perrigo et al. (1979) noted that other parts of the reactor complex, notably the radwaste system, can have high radiation fields, even during normal operation. During decommissioning operations, the entire plant comes under scrutiny and must be considered for decontamination. 


\section{BWR and PWR System Characteristics}

The two basic types of power reactors--pressurized water reactors (PWRs) and boiling water reactors (BWRs)--differ both in materials of construction and operating conditions. Consequently, the applicability of a given decontamination solution varies depending on reactor type. The primary system of a pressurized light water reactor (LWR) (see Figure 2) uses 200 to $300^{\circ} \mathrm{C}$ water as the coolant. Sufficient pressure is maintained to keep the water as a liquid at all times. A hydrogen overpressure is used to maintain low oxygen levels and results in corrosion products containing reduced species. The major components of a PWR system are the core, pressure vessel, primary side of the steam generator, primary pumps, primary system piping, the pressurizer, and associated instrumentation.

The following percentages are indicative of the relative amounts of alloy surface area in contact with the primary coolant: Inconel, 65 to $70 \%$; Zircaloy, 25 to 28\%; stainless stee1, 4 to $6 \%$; and Stellite or other hard surfacing alloys, about 1\% (Choppin et al. 1979; Uhl and Shaw 1976). The choice of these materials and the amounts present determine the type of contamination, the type of films that form in the primary system, and the ease of decontamination. Except in the case of dilute solutions, Zircaloy (fuel) probably will not be in the reactor during decontamination. In discussions with a number of people concerned with radiation exposure, it appears that housekeeping (that is, the adherence to operating specifications) is a factor that overrides the effect of material. A review of some unpublished data indicates that for essentially identical plants, radiation fields and of ten plant exposure rates can be significant in one and small in the other.

To generate power from the reactor heat, a PWR transfers the heat from the pressurized primary system to a lower pressure, nominally uncontaminated secondary system. Steam generated in the secondary system is used to drive the turbines for electrical power generation. Because of leaks in the steam generator and the direction of the pressure gradient (low on the secondary side), the secondary side may also become contaminated to some degree. The secondary system uses a different water chemistry and different materials than the primary system, which results in different types of corrosion products. 


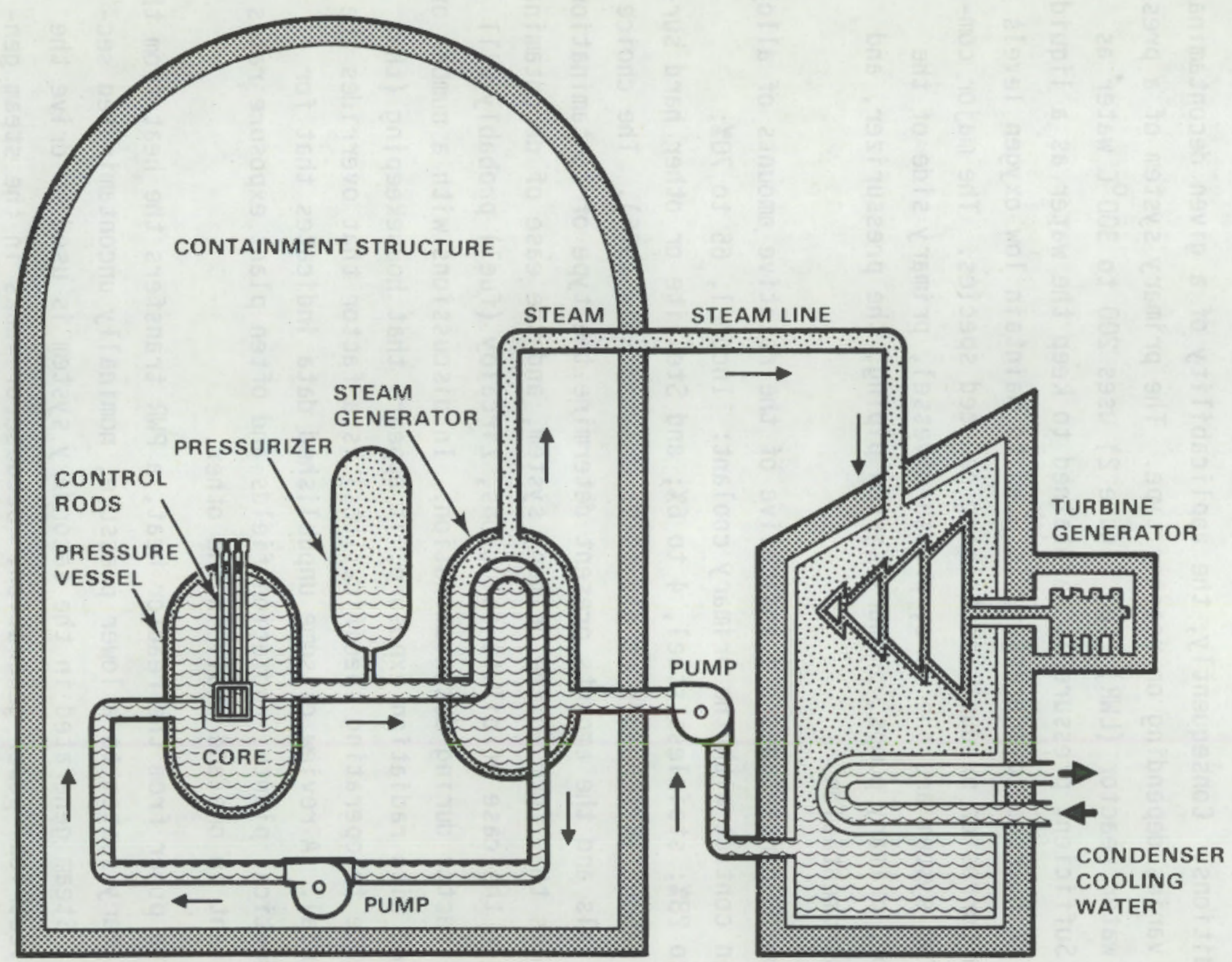

FIGURE 2. Simplified Diagram of a Pressurized Water Reactor (PWR) 
Direct-cycle BWRs (see figure 3 ) permit boiling in the reactor vessel with the steam that is generated fed directly to the turbines. BWRs operate with a slight excess of oxygen, and the corrosion products tend to be in the oxidized form; chromium is a prime example--it exists as the insoluble $\mathrm{Cr}^{+3}$ in a PWR but as the soluble $\mathrm{Cr}^{+6}$ in a BWR. The principal components of a BWR system are the core, pressure vesse1, steam and condensate piping, steam turbine, condensate pumps, and condenser as well as associated instrumentation. Although component materials vary from one facility to another, the following percentages are indicative of the areas of major component alloys within the primary system: stainless steel, 38 to $42 \%$; carbon steel, 16 to 20\%; Zircaloy, 40 to 44\%; and Inconel, less than 1\% (Chopp in et al. 1979; Uhl and Shaw 1976). As noted for PWR systems, Zircaloy may not be present in the reactor during decontaminaton. Further, adherence to operating specifications can significantly influence attendant radiation fields.

\section{Other Systems}

In addition to the containment building and its immediate piping, radioactive contamination is also encountered in turbine buildings, radwaste buildings, and contaminated laundry. Although piping and storage systems are designed to contain radioactivity (except for controlled releases), leaks occur in practice due to deterioration of components or operational error.

Only within the reactor vessel and the reactor shield will there be radioactive products generated within structural materials. All other areas will have only surface contamination introduced from other sources. This includes contamination that has soaked into permeable materials such as concrete.

Decontamination of activated materials such as fuel cladding, vessel, internal hardware, and bio-shield components is beyond the scope of this program except for removal of loose surface deposits to prevent possible spread of the contamination. All other piping and structural materials are possible decontamination subjects, including the interior of radioactive material transport piping, the exterior of any other piping or tubing, concrete (painted or bare), other painted surfaces, floor coatings, and soil (spills that penetrate cracks in the concrete or occur outdoors). 


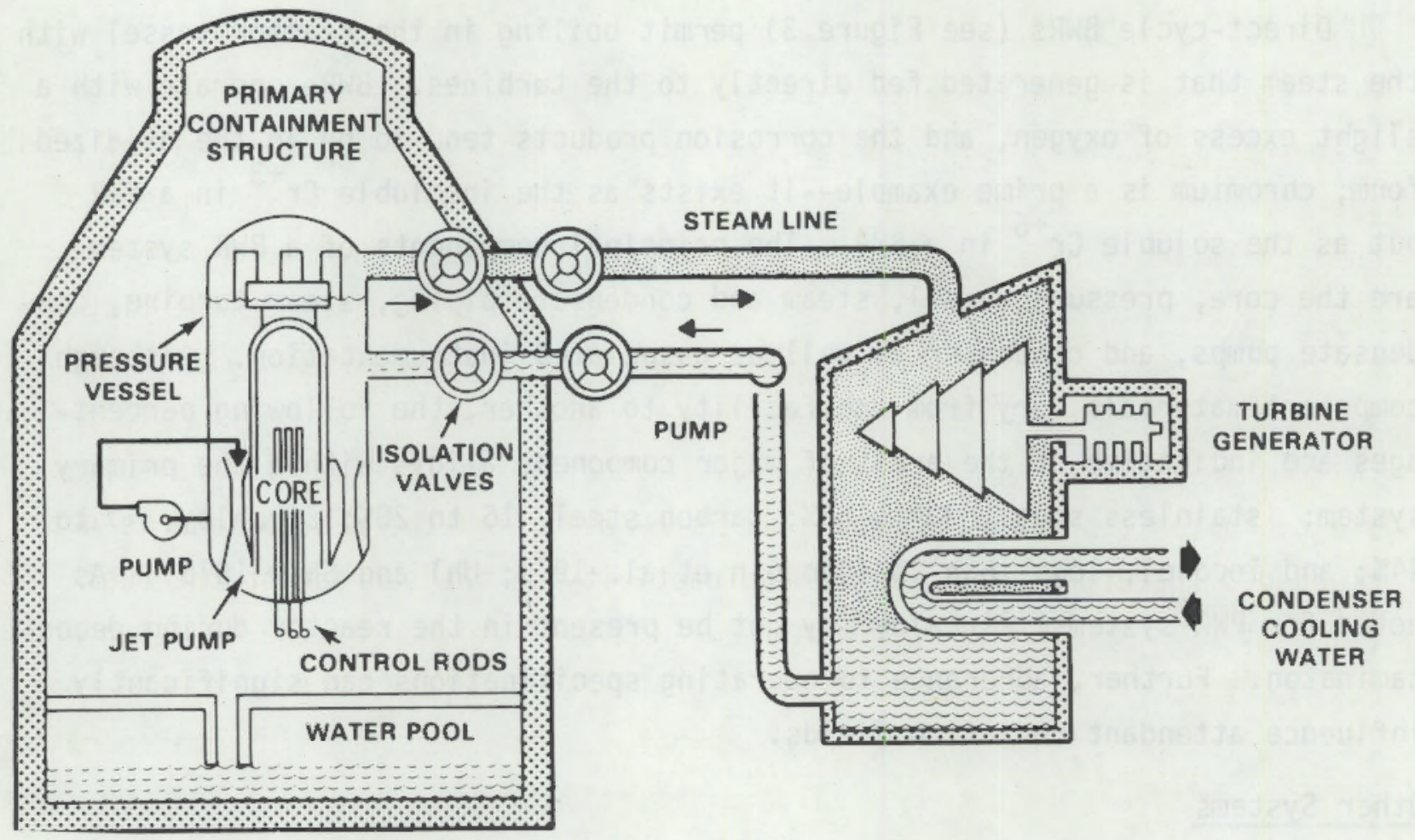

FIGURE 3. Simplified Diagram of a Boiling Water Reactor (BWR)

Concrete surfaces within nuclear facilities become contaminated with radionuclides by spills, leaks, or accidental release of contaminated vapors. If it is determined that the contamination has not significantly penetrated the surface, vacuuming and scrubbing with a mild detergent may give satisfactory results. In most cases where concrete, particularly uncoated concrete, has become contaminated by liquids, the contamination will have significantly penetrated the concrete. Successful decontamination methods in the past have centered on removing the concrete surface to the required depth so that the remaining concrete can be given an unconditional release. There is, however, considerable research interest in techniques such as electrodialysis that would transport the radionuclides in solution out of the concrete, offering many orders of magnitude reduction in waste volume. 
CHEMICAL DECONTAMINATION METHODS

The terms "high-concentration" and "dilute" or "low-concentration" processes are generally reserved for the decontamination of reactor coolant piping systems and their associated unit operations equipment. Solutions used to chemically decontaminate structural components, tools, laboratory ware, or other nonprocess equipment are ordinarily not so distinguished. The distinction arises because reactor coolant system design requires that a fill and drain process be used to flush out concentrated chemicals properly. To prevent the fuel elements from overheating during the drain cycle and to prevent possible corrosion attack on the fuel, it is removed from the reactor and is not cleaned. Therefore, most of the radioactivity on the surface of the fuel elements--the source of contamination-- is not eliminated by the cleaning process. With dilute processes, which use a feed and bleed technique, the fuel can remain in the core and be decontaminated. Furthermore, high-concentration systems require a larger chemical and radwaste handling facility than do lowconcentration systems (Perrigo and Divine 1979). Hand tool and component chemical decontamination uses a concentrated process because total solution volumes are relatively low, the operation is small enough to be easily controlled, and high DFS are desired and easily obtained.

Most of our decontamination experience has been for the purpose of continued operation (for example, decontamination of the primary system). Decommissioning expands the application of decontamination work to all portions of a facility; therefore, the chemistries and techniques involved must be appropriate not only to piping and process systems but also to other construction materials. In addition, the available power in a shutdown plant may be reduced so that minimal flow and temperature conditions may prevail. To compensate, time, corrosion, and concentration restraints are more relaxed.

To the extent that separation is possible, the designations of high- and low-concentration processes will continue to be applied to maintain continuity with established nomenclature. 


\section{High-Concentration Processes}

Generally, solutions with greater than $2000 \mathrm{ppm}(0.2 \%)$ of reagent fall into the high-concentration classification (Remark and Miller 1979). Highconcentration systems are usually more corrosive to the base metal, more expensive, and harder to remove and require more expensive preparation and waste treatment systems than their dilute counterparts. However, high-concentration processes are effective in removing contamination in a single step.

High-concentration processes are generally divided into one-step or twostep processes plus required flushes. In either, additional steps or cycles can be performed, but they are generally repeats of the initial process(es).

Although the major emphasis in this section will be on the removal of activated corrosion products, it is necessary to consider that on occasion fuel debris from ruptured fuel elements may have to be removed. It has been inferred (Divine 1973) that some processes (Table A.1, No. 51) perform both types of decontamination simultaneously albeit with relatively high corrosion rates. In contrast, there are other processes (Table A.1, No. 52 and 53) that have very low corrosion rates and are designed to remove only fuel debris. Fuel removal processes are combinations of acids (organic or inorganic), oxidizing agents, and complexants for plutonium and uranium.

\section{Multistep Processes}

Two-step processes that are used for corrosion product removal are most suitable for films generated in PWR conditions. The first step generally is an oxidizing step designed to convert $\mathrm{Cr}^{+3}$ and other reduced species to a more soluble oxidized state. Typical examples of two-step processes are alkaline permanganate (AP) followed by a complexant/acid solution (Table A.1, No. 38) or nitric acid followed by a complexant/acid solution; that is, an oxidizing step followed by a dissolution step.

The AP solution ( 3 to $20 \% \mathrm{NaOH}, 1$ to $5 \% \mathrm{KMnO}_{4}$ ) is typically used at 100 to $110^{\circ} \mathrm{C}$ for anywhere from 2 to $24 \mathrm{hr}$. On stainless steel, Inconel, and Incoloy the permanganate oxidizes the $\mathrm{Cr}^{+3}$ to $\mathrm{Cr}^{+6}$ (as $\mathrm{CrO}_{4}=$ ), which is soluble. As will be discussed later, the remaining films are usually removed by complexants or acids. With stainless steel, the surface crystal structure 
is destroyed by AP, leaving a relatively homogeneous layer of disintegrated crystals (Ayres 1971). The decontamination obtained with AP alone is essentially zero. Although the ${ }^{51} \mathrm{Cr}$ is almost totally removed, it generally contributes little to the radiation field and, therefore, little to the DF. The AP has little apparent effect on carbon steel films formed after exposure to high-temperature water, with only some slight corrosion noticeable (Ayres 1970).

Stainless steel films with high nickel content and little chromium are not appreciably affected by AP and remain insoluble to hot dilute acids (Ayres 1970).

Unpublished laboratory data taken at room temperature show that copper is uniformly attacked in AP at a rate of $0.13 \mu \mathrm{m} / \mathrm{hr}(0.005 \mathrm{mil} / \mathrm{hr})$. Based on discussions in Uhlig (1948) attack is expected to be high at higher temperatures.

Materials such as chromium and some of the Haynes Stellites suffer localized attack (Weed 1962; Ayres 1971). Weed tabulates the effect of varying the sodium hydroxide concentration. There is an initial rapid increase in corrosion ratewith increasing concentration, but the rate of increase slows and may decrease as the concentration passes $180 \mathrm{~g} / 1 \mathrm{NaOH}$. Similarly, the corrosion rate peaks at about $7.5 \mathrm{~g} / 1 \mathrm{KMnO}_{4}$ and then decreases. The effectiveness of AP in oxidizing $\mathrm{Cr}^{+3}$ increases as the temperature exceeds $100^{\circ} \mathrm{C}$ but so does the corrosion rate. Weed's data show significant fluctuation but suggest corrosion rates of 0.1 to $0.3 \mathrm{mil} / \mathrm{hr}$ for these alloys. Because $\mathrm{KMnO}_{4}$ is highly oxidizing, organic-based materials are also attacked.

It is important to note, however, that pure $\mathrm{NaOH}$ must be used; the usual technical grade contains around $1 \% \mathrm{NaCl}$. Any residual chloride left in the system can cause stress corrosion cracking (SCC) of 300 series stainless steel (SS). Possible corrosion effects of residual $\mathrm{NaOH}$ also mean that the solution should be thoroughly removed by flushing and draining of deadlegs.

Dibasic ammonium citrate (AC) solution preceded by AP (APAC) and a water rinse is capable of removing 90 to $98 \%$ of deposited corrosion product activity from smooth surfaces such as stainless steel. It is ineffective on material entrained in crevices or deadleg areas (Abrams and Salterelli 1966) and on 
scaled 347 SS (Ayres 1971). The AC step neutralizes any residual $\mathrm{NaOH}$ and dissolves residual $\mathrm{MnO}_{2}$ from the AP step and then attacks the remaining corrosion product film. A dilute $A C$ step can be used after initial rinses to remove excess AP before proceeding to the main $A C$ solution to keep the main $A C$ solution at full strength. DFs from 5 to 20 are reported, depending upon the extent of redeposition of the corrosion products (Remark 1978).

The AC step is generally applied for 24 to $48 \mathrm{hr}$ at about $95^{\circ} \mathrm{C}$. Ayres (1971) reports that the corrosion rate for carbon steel does not change greatly between 85 and $95^{\circ} \mathrm{C}$. Weed (1962) reports carbon steel corrosion rates of approximately $2.5 \mu \mathrm{m} / \mathrm{hr}(0.1 \mathrm{mil} / \mathrm{hr})$ and suggests $1.3 \mu \mathrm{m} / \mathrm{hr}(0.05 \mathrm{mil} / \mathrm{hr})$ as an allowable upper limit. Corrosion rates can be limited to this value with inhibitors such as 1,3-diethyl-2-thiourea.

Weed (1962) also summarizes laboratory decontamination data from different sources; see Table 2 for the results of varying the $A C$ step. In most cases these are changes of the form of the citrate but other chemicals are included for comparison. In Table 3 the effect of velocity on the DF is shown; tests 5 , 6 , and 7 demonstrate the variability of results from similar tests.

The spent APAC solutions can be deionized with mixed bed demineralizers, and the resins can be treated as solid wastes (Cerré 1970).

The APAC with ethylenediaminetetraacetic acid (EDTA) process (APACE) is the same procedure as the previous one but with EDTA added to the second step to serve as a complexing agent. An EDTA concentration from 0.25 to $0.5 \%$ by weight will help prevent redeposition of active corrosion products (Ayres 1971).

The two-step AP-oxalic acid process (APOX) has been somewhat successful in removing aged films on high-temperature SS water piping. The oxalic acid step is typically run at $85^{\circ} \mathrm{C}$ for about $2 \mathrm{hr}$ to give a DF (without redeposition) of 16 (Weed 1968; Ayres 1971). Contact times beyond this begin to form the insoluble ferrous oxalate. Once formed, the redeposition films cannot be removed by flushing. In these cases, it is sometimes necessary to use a third solution containing dibasic AC to achieve satisfactory decontamination (Weed 1968). Redeposition was a strong influence in the development of the citrox process. 
TABLE 2. Conditions Evaluated and Results Obtained on Stainless Steel with the Modified Alkaljne Permanganate-Anmonium Citrate Procedure(a)

\section{Reagents}

1-A. Pretreatment with: sodium hydroxide potassium permanganate

1-B. Final treatment with: ammonium citrate sodium citrate ammonium citraterodine- 130 sodium citraterodine- 130

citric acid

citric acidhydrogen peroxide

2-A. Pretreatment with: sodium hydroxide potassium permanganate

2-B. Final treatment with: oxalic acid ammonium citrate

citric acid nitric acid

3-A. Pretreatment with: sodium hydroxide potassium permanganate

3-B. Final treatment with:

nitric acid nitric acid

4-A. Pretreatment with: sodium hydroxide potassium permanganate

4-B. Final treatment with: nitric acid oxalic acid ammonium citrate ammonium citrate citric acid

Concentration, Exposure
$\mathrm{g} / \mathrm{l}$

10
5

100

100

100

12.5

100

12.5

100

100
Temperature, Decontamination Factor
30

4

1
1
1

1

1

0.5

50
25

\section{5}

85

85

85

85

85

95

50
50
100
10 vol\%

0.5

0.5

0.5

0.5

0.5

50
0.5

1

0.5

50

10 vol\%
100
50
50
50

0.5
0.5
0.5
0.5
0.5
95

95

90

95

85

85

25

95

(a) Weed 1962

(b) Pretreatment $(2-A)=60$ min contact.

(c) Pretreatment (4-A) at $100^{\circ} \mathrm{C}$. 
TABLE 3. Effect of Velocity on the Decontamination Factor Achieved with the Alkaline Permanganate-Ammonium Citrate Procedure

Test (a)

1

2

3

4

5

6

7

8
Linear Velocity of Decontaminants,

mps

0.046

0.076

0.12

0.30

1.5

1.5

1.5

3.0
Average

Decontamination

Factor

46

92

93

1,150

657

158

8,820

27,000

(a) AISI Type 304 SS.

Ayres (1971) describes the AP-citrox process and states that of the many variations of acid step "the reagent that has given the best results during an actual reactor decontamination is citrox..." The citrox formulation is given in Table A.1, No. 33. Dilute citrox may be used as an intermediate step to remove the last traces of AP.

The principal application of the AP-citrox process has been on stainless steel, but success has also been noted on Inconel and carbon steel. No sulfate can be present in the citrox or the Inconel corrosion rate will be very high (Ayres 1966).

Inhibited $9 \%$ sulfamic acid by itself is an excellent reagent for removing films from carbon steel (Ayres 1966); and when used in conjunction with an AP pretreatment, it has been shown to be effective on stainless steel and aluminum with only minimal corrosion (Manion 1980). The sulfamic acid portion of the treatment is performed at 70 to $80^{\circ} \mathrm{C}$ for 2 to $6 \mathrm{hr}$, and typical DFs are about 20 (Ayres 1970). 
Stainless steel, low and high carbon steels, and ferrous alloys containing chromium, molybdenum, tungsten, manganese, nickel, and other transition metals have all been descaled by treatment in AP followed by pickling in $\mathrm{HCl}, \mathrm{H}_{2} \mathrm{SO}_{4}$, or other nonoxidizing acids (Posselt and Anderson 1967). These processes have not been tested as decontamination agents on all of the metals in reactor systems. The adherent magnetite films that form on stainless steel in PWRs can be removed with a two-step treatment of AP followed by $10 \% \mathrm{HNO}_{3}$ (Ayres 1966). Components from the steam generators at Shippingport and Sena and from the NReactor at Hanford have been decontaminated using AP followed by sulfuric acid, diammonium citrate, or ammonium oxalate plus diammonium citrate. All reagents contained a suitable corrosion inhibitor such as listed in Tables A.1, Nos. 29-101; and DFs were about 10.

In laboratory tests, stainless steel conditioned in AP has been treated with a $3 \%$ solution of triethylenetetraamine hexaacetic acid (TTHA), citric acid, hydrazine, and hydroxylamine of equal proportions by weight. At $98^{\circ} \mathrm{C}$ a DF of 20 was reported after $30 \mathrm{sec}$ of treatment, and within 5 min the DF was 250 with a light tan film remaining on the surface. Complete defilming was reported after $1 \mathrm{hr}$ with a DF of 4000 . Similar results were obtained when EDTA was used instead of TTHA; the pH of each solution was 7 to 8 (Ayres 1971). An advantage to certain reagents such as hydrazine, hydroxylamine, EDTA, and some organic acids is that they decompose in heat and radiation fields to form harmless substances such as ammonia and carbon dioxide (Ayres 1966). Use in large systems would be difficult if decomposition, corrosion, or redeposition are too fast because of the time required to feed and remove the chemicals.

\section{Decontamination Techniques Using Acids}

Acidic decontamination reagents (mineral acids) are used in concentrations of 5 to $15 \%$ with an inhibitor such as propynol or formaldehyde. Uniform corrosion rates are generally 0.02 to $0.2 \mathrm{mg} / \mathrm{cm}^{2}-\mathrm{hr}(0.3-3 \mathrm{~m} / \mathrm{yr}$ for iron) and are acceptably low for short time use. The primary danger lies in the possibility of a localized attack such as pitting; however, this is of little consequence for decommissioning if the rate is sufficiently low. 
Uninhibited hydrochloric acid is useful in removing corrosion product films but is extremely corrosive to mild steel and can cause SCC of 300 series SS. A process of adding hydrazine to the $\mathrm{HCl}$ to raise the $\mathrm{pH}$ to 8.5 and reduce carbon steel corrosion rates to less than $23 \mu \mathrm{m} / \mathrm{hr}(0.01 \mathrm{mil} / \mathrm{hr})$ has been reported for use on boilers and piping systems (Ayres 1971).

The primary applications for $\mathrm{HCl}$ in decontamination work have been with stainless steel (non-300 series), Cr-Mo steel, carbon steel, and copper alloys. Application of the process at a solution temperature of $70^{\circ} \mathrm{C}$ for $2 \mathrm{hr}$ typically achieves a DF of 10 (Manion 1980).

Nitric acid is used on systems of austenitic stainless steel or aluminum. These materials passivate in the presence of strong oxidizing agents and therefore fail to corrode as rapidly as might be expected.

Stainless steel DFs of greater than 1000 have been achieved with the following extremely corrosive procedure (Christensen 1959):

- water rinse and do not allow to dry

- scrub with $30 \% \mathrm{HNO}_{3}$

- scrub with $20 \% \mathrm{NaOH}-10 \% \mathrm{Na}$ tartrate for 30 min

- $10 \%$ oxalic acid for $1 \mathrm{hr}$; rinse

- $3 \% \mathrm{HF}-20 \% \mathrm{HNO}_{3}$, if necessary.

Overall, this procedure will uniformly corrode the surface at somewhat less than $254 \mathrm{\mu m} / \mathrm{hr}(10 \mathrm{mil} / \mathrm{hr})$. The $\mathrm{NaOH}$-tartrate acts as a complexant to prevent redeposition. The efficiency increases with temperature; $55^{\circ} \mathrm{C}$ is typical for the $\mathrm{HNO}_{3}$ and 60 to $80^{\circ} \mathrm{C}$ is typical for the complexant. Because the application requires scrubbing, the procedure is not suitable for use inside long reaches of piping or in high-radiation fields.

Aluminum can be completely decontaminated with a solution of $10 \%$ $\mathrm{HNO}_{3}-3 \% \mathrm{HF}$ at room temperature although corrosion is severe and caution needs to be exercised in its use. Further, because of the chemical behavior of HF, operators must be carefully trained in its use (Christensen 1959).

Nitric acid has been used for up to $24 \mathrm{hr}$ at $99^{\circ} \mathrm{C}$ to remove most of the uranium contamination from Zircaloy fuel cladding (Table A.1, No. 106). The 
nitric acid is followed with an ammonium oxalate-AC-armonium fluoride-hydrogen peroxide solution to remove the remaining uranium and etch the Zircaloy (Platt 1975).

A $10 \%$ nitric acid solution at $75^{\circ} \mathrm{C}$ has been used to remove uranium metal and uranium oxides from stainless steel and Inconel systems (Ayres 1971). Copper alloys have also been decontaminated (Manion 1980; Loucks 1971). The latter procedure is recommended only for component cleaning where the degree of corrosion can be monitored.

Brass has been decontaminated with concentrated nitric acid ( 4 parts acid to 1 part water) by treatment for $5 \mathrm{sec}$ at $50^{\circ} \mathrm{C}$ (Ayres 1971). This is clearly a batch process requiring good control.

Sulfuric acid in dilute inhibited form is recognized as useful for defilming some metals. Sulfates of calcium, barium, and strontium are insoluble and may form, causing redeposition of contamination and blocking of narrow passages (Ayres 1971).

Anhydrous $\mathrm{H}_{2} \mathrm{SO}_{4}$, concentrated $\mathrm{H}_{2} \mathrm{SO}_{4}, \mathrm{H}_{3} \mathrm{PO}_{4}$, and $\mathrm{H}_{2} \mathrm{SO}_{4}-\mathrm{HNO}_{3}$ have been used successfully to remove plutonium oxides from piping systems. Concentrated $\mathrm{H}_{3} \mathrm{PO}_{4}$ and $\mathrm{H}_{2} \mathrm{SO}_{4}-\mathrm{HNO}_{3}\left(95 \% \mathrm{H}_{2} \mathrm{SO}_{4}-5 \% \mathrm{HNO}_{3}\right)$ have been successful in dissolving mixed $\mathrm{PuO}_{2}-\mathrm{UO}_{2}$ oxides (Ayres 1966; Lerch 1975; Divine 1973). At $155^{\circ} \mathrm{C}$, the corrosion rate of $304 \mathrm{SS}$ in the various acids is less than $1 \mathrm{mil}$ /day (the $\mathrm{H}_{3} \mathrm{PO}_{4}$ has to be inhibited with ferric ion). Unpublished data show that Zircaloy-2 has a catastrophic corrosion rate in $\mathrm{H}_{2} \mathrm{SO}_{4}-\mathrm{HNO}_{3}$ at $250^{\circ} \mathrm{C}$; samples are destroyed in a few hours.

Mixtures of sulfuric acid, oxalic acid, and phenylthiourea have been used to decontaminate in-reactor coolant loops composed of aluminum, carbon steel, and Zircaloy-2 with DFs of 3 to 4 .

Inhibited sulfamic acid $\left(\mathrm{NH}_{2} \mathrm{SO}_{3} \mathrm{H}\right)$ has been used to decontaminate mild steel and aluminum. It avoids reprecipitation and usually does not cause severe attack at galvanic junctions. Monel and nickel that have been exposed to water at $300^{\circ} \mathrm{C}$ or lower can be cleaned by immersion in $25 \%$ sulfamic acid for $1 \mathrm{hr}$ at boiling (Ayres 1971). While not as active as phosphoric acid, this 
acid has been used with some effectiveness on carbon steel where it is mildly corrosive. Treatment for $4 \mathrm{hr}$ at $80^{\circ} \mathrm{C}$ will typically give a DF of 3 on carbon steel (Meservey 1970).

A solution of oxalic acid and hydrogen peroxide can be used to polish mild steel (Ayres 1971). A smooth surface with a bright finish can be obtained in 15 min at $35^{\circ} \mathrm{C}$. Typical concentrations will be $0.25 \mathrm{M} \mathrm{H}_{2} \mathrm{C}_{2} \mathrm{O}_{4}$ and $0.3 \mathrm{M} \mathrm{H}_{2} \mathrm{O}_{2}$. The cleaning action and corrosiveness are controlled by adjusting concentrations and temperature: At high temperature, oxalic acid rapidly destroys the peroxide; recommended temperatures run up to $60^{\circ} \mathrm{C}$ (Ayres 1971).

A solution composed of $0.4 \mathrm{M}$ oxalic acid, $0.1 \mathrm{M} \mathrm{HF}$, and 0 to $1.0 \mathrm{M} \mathrm{H}_{2} \mathrm{O}_{2}$ was used to decontaminate stainless steel, and a DF of 12 was reported after treatment for 2 to $4 \mathrm{hr}$ at 25 to $95^{\circ} \mathrm{C}$ (Ayres 1971).

Solutions containing oxalic acid, citrate, and peroxide can be used for decontaminating mild steel at room temperature if the peroxide concentration is lower than $0.08 \mathrm{M}$ (Ayres 1971).

Material from ruptured fuel elements has been removed from reactor cores by a buffered mixture of oxalic acid and hydrogen peroxide (Ayres 1966). Uranium- and plutonium oxide-contaminated Zircaloy-2, stainless steel, and carbon steel have been decontaminated with this same mixture plus gluconic acid. DFs were about 6 with less than $0.10 \mu \mathrm{m} / \mathrm{hr}(0.004 \mathrm{mil} / \mathrm{hr}$ ) of corrosion (Divine 1973).

Citric acid is used in combination with other reagents in both high and low concentrations. Its principal function is to complex with ferrous ions, preventing their redeposition. Citric acid added to oxalic acid complexes the iron and reduces ferrous iron concentration to such a low value that the ferrous oxalate precipitate will not form.

Hydrofluoric acid has been used to decontaminate stainless steel in solutions that include ammonium oxalate, $A C$, and hydrogen peroxide. In tests with HF concentrations of $0.5 \mathrm{M}$, plutonium DFs of 400 to 1700 have been obtained. With $0.1 \mathrm{M} \mathrm{HF}$, the same tests will give DFs of 20 to 100 . Nitric-hydrofluoric acid decontamination solutions will give approximately the same results (Platt 1975; Dillon et al. 1976). 
The zirconium oxide layers from corroded fuel hulls have been removed in a gaseous mixture of $\mathrm{HF}$ and argon at $600^{\circ} \mathrm{C}$ followed by aqueous organic acid stripping (see Table A.1, Nos. 107-119) (Platt 1975).

\section{NS-1}

Dow Chemical Company markets the proprietary process NS-1 principally for the decontamination of stainless steel and carbon steel in BWR systems. Reported DFs range from 5 on a heat exchanger system, to 500 on a test conducted in the out-of-reactor portion of a loop at the Dresden-1 reactor, and to 2000 in a test loop with radioactive samples. The reagents are circulated through the reactor system for 100 to $200 \mathrm{hr}$ at 210 to $250^{\circ} \mathrm{F}$ under a nitrogen blanket.

A Dow study of the corrosive properties of NS-1 was conducted in preparation for its use at Dresden-1. Most of the testing was performed at $250^{\circ} \mathrm{F}$ for around $100 \mathrm{hr}$ to simulate the expected use. Higher temperature testing was also performed to study corrosion and SCC at $275^{\circ} \mathrm{F}$ and effects of NS-1 decomposition at $575^{\circ} \mathrm{F}$. The tests were performed under a nitrogen blanket and with oxygen access permitted.

Results of the tests showed that for 1020 carbon steel, some low alloy steels, 2-1/4 Cr-1 Mo, and 400 series SS, the corrosion rates were about 0.003 to $0.014 \mu \mathrm{m} / \mathrm{hr}$ (Dow 1977). The effect of temperature in some cases was significant. Incoloy 800 at $250^{\circ} \mathrm{F}$ had corrosion rates of $0.002 \mu \mathrm{m} / \mathrm{hr}$, whereas at $275^{\circ} \mathrm{F}$ the reported rates were 10 times larger. Although the reason for this rather large increase is not known because of the proprietary nature of the solution composition, discussions with various workers in this field suggest that the inhibitor breaks down in this temperature range.

This information is but a small sampling of the data presented in the original documentation, which also describes the work needed to qualify the new decontamination solvent. 


\section{Dilute Processes}

Dilute solutions contain less than $0.2 \%$ reagent and generally less than $0.1 \%$. Their primary advantage over concentrated solutions is that they are dilute enough to be removed with a relatively small amount of ion-exchange resins that can be readily tied into the primary system and require no rinses or spent solution storage. Consequently, a feed and bleed mode of operation can be used that allows the fuel to remain in the core and be cleaned, if desired. The level of decontamination reagent can be maintained by continuous addition or by on-line regeneration. Because of their low concentration and generally short use time, the DF attained is small (usually less than 5). Another reason for the low DF is that with the large source of radioactive material present on the surface of the fuel, some transportation of radioactivity is expected, especially to originally low activity sites; this might give rise to a DF of less than 1 in low flow areas.

\section{Complexing Agents}

EDTA and its homologues nitriloacetic acid (NTA); diethylenetriaminepentaacetic acid (DPTA); TTHA; and hydroxyethylenediaminetriacetic acid (HEDTA) complex with iron, nickel, cobalt, chromium, and many other di- and trivalent ions. The formation of the complexes increases the solubility of the complexed ions and therefore enhances their removal from deposits, scales, or corrosion films. Even if a radionuclide is not specifically complexed, the complexant may remove a sufficient number of other ions to cause the film to disintegrate and release radionuclides in particulate form. The stability of the complexes under changing thermal, $\mathrm{pH}$, and radiolytic effects tends to increase with increasing molecular weight.

High-temperature films from mild steel and the conditioned hightemperature films on stainless steel can be removed with a mixture of citric acid and EDTA ( $\mathrm{Na}$ salt) at a pH of around 7. The removal rate becomes effective at around $100^{\circ} \mathrm{C}$ and improves with increasing temperatures in pressurized systems up to the decomposition temperature of the chelating agent. Ammonium hydroxide and hydrazine are the reagents most of ten used for $\mathrm{pH}$ control. 
Hydrazine is preferred because it reduces ferric ion to the more soluble ferrous and reduces the tendency for pitting (Ayres 1971). When used alone, typical concentrations of these complexing reagents will be 400 to $500 \mathrm{ppm}$.

NUTEK L-106. This is a proprietary reagent supplied by Nuclear Technology Corporation and is the forerunner of the CAN-DECON chemicals. It was used successfully to decontaminate the Douglas Point Generating Station in Canada with DFs of 6 to 10 . The contaminated solution is regenerated with an ion exchange resin in the same fashion as CAN-DECON.

CAN-DECON. This proprietary process was developed by Atomic Energy of Canada Limited (AECL) and Ontario Hydro; it is a dilute application of reagents normally used in higher concentration processes (such as citric acid, oxalic acid, and EDTA). Because it was developed for use in the Canadian heavy water reactors (HWRs), there was an incentive to use as low a concentration as possible to minimize the amount of hydrogen exchange with the deuterium in the heavy water. The final concentration was about $1000 \mathrm{ppm}(0.1 \%)$.

During the decontamination operation, which runs for 24 to $48 \mathrm{hr}$ at 85 to $125^{\circ} \mathrm{C}$, the solution is filtered and partially regenerated by passage through cation exchangers. Complete regeneration is not possible because of the loss of active chemicals through radiolysis. At the end of the operation, the chemicals are removed by mixed bed ion exchangers.

Manion (1980) suggests that normal DFs of about 5 to 10 can be increased to about 15 if temperatures are increased to $150^{\circ} \mathrm{C}$ and concentrations are increased to 0.5 wt\%--the maximum allowed in a heavy water system. The process has not proven suitable for PWRs because of a difference in corrosion product films.

Other Reagents. Although all of the processes described above have been liquids, other forms are possible. Ayres (1971) briefly discusses foams and gels formulated with hydrochloric acid; Dippel, Hentschel, and Kunze (1976b) describe a paste. It would appear that many of the previously described systems could be incorporated as a foam, gel, or paste. 
Foams have advantages and disadvantages when compared with liquids. Typically foam is more usable in vertical dual pass heat exchanger tubes because it will fill the tube and not drain out the downstream side. Further, thin films will probably yield faster reactions, less total liquid volume will be involved, and there will be little velocity effect. However, the lower mass of the foam will make temperature control more difficult and provide less cleaning capacity. No information is available on decontamination ability or corrosion behavior.

No useful information was found on gels. Ayres (1971) notes the use of phosphoric acid gelled with hydroxyethyl cellulose to clean ferrous metals. A similar gel and one suitable for aluminum are commercially available in most hardware stores.

Dippel, Hentschel, and Kunze (1976b) describe a cleaning paste used on stainless steel (German steel 1.4541, which is similar to AISI 321 SS). Cleaning pastes usually consist of a filler, a carrier, and an acid or mixture of acids as the active agent. Generally, the pastes used in pickling operations are not effective for decontamination because the acids they contain are not highly efficient. Good results have been achieved with a paste containing a mixture of hydrofluoric and nitric acids with a small amount of hydrochloric acid. Polyethylene granulate has been used as a filler and titanium dioxide powder as the carrier. A drawback of this system is that the filler and carrier materials constitute a substantial portion of the radioactive wastes that are produced while providing no decontamination action themselves. However, the final volume is still small compared to liquids and does not require a volume reduction treatment such as evaporation.

The paste Dippel describes gave DFs of 50 to 100 at room temperature; no corrosion data were provided. At present it is applied manually, but there is potential for mechanical application.

Molten salts are decontamination agents that do not contain inactive additives. It has been shown that molten salt mixtures yield high DFs especially against firmly adhering corrosion layers. Some representative examples of molten salt mixtures studied include: $\mathrm{KCl} / \mathrm{NaCl} / \mathrm{AlCl}_{3} ; \mathrm{NaOH} / \mathrm{KOH} / \mathrm{Na}_{2} \mathrm{O}_{2}$; 
$\mathrm{NaOH} / \mathrm{KOH} / \mathrm{Na}_{2} \mathrm{O}_{2} / \mathrm{Na}_{2} \mathrm{CO}_{3} ; \mathrm{Na}_{2} \mathrm{CO}_{3} ; \mathrm{NH}_{4} \mathrm{H}_{2} \mathrm{PO}_{4} ; \mathrm{KH}_{2} \mathrm{PO}_{4}$; and $\mathrm{NH}_{4} \mathrm{H}_{2} \mathrm{PO}_{4} / \mathrm{KH}_{2} \mathrm{PO}_{4}$. The most suitable salts with respect to corrosion, decontamination, and waste form compatibility appear to be the phosphates. Temperatures range from 100 to $300^{\circ} \mathrm{C}$ with DFs of 20 to 100 .

Salt melts can be applied by a hot spraying technique that makes it possible to apply salt powders to metallic surfaces in layer thicknesses of $0.1 \mathrm{~mm}$ (0.004 in.) (Dippel, Hentschel, and Kunze 1976a).

In general, the chemicals involved in decontamination solutions exhibit no special problems; but standard safety precautions clearly must be taken because of the strong oxidants (fire hazards), complexants, in particular oxalic acid (physiological hazards), or strong acids (burns). In addition, some chemicals that have been used in decontamination solutions are now classified as potential carcinogens and require either a substitute or special care in storage and handling.

MECHANICAL DECONTAMINATIDN METHODS

Mechanical decontamination methods are generally less versatile than chemical methods, and they are restricted to exposed surfaces that are accessible from some exterior point. For example, both chemical and mechanical methods can be used in pipelines; a "pig" can be mechanically pushed through the line and around corners to abrade the surface. However, the mechanical system will not be able to handle a tank in the pipeline without a discrete break at that point.

The processes that are described in this section are suitable for surfaces (concrete, paint films, corrosion product films) and the bulk sectioning of equipment and structures. The cleaning of any surface should meet the following criteria:

- minimar personnel exposure (direct and inhalation)

- minimal recontamination of previously cleaned surfaces

- minimal volume of contaminated material to be stored

- minimal time required for removal

- minimal offsite release. 


\section{Spalling}

The concrete spaller that was developed by PNL has three basic parts: a hydraulic cylinder, a push rod, and a bit with expanding wedges (see Figure 4). The cylinder activates the push rod, which is installed inside the bit. The bit is fabricated of steel tubing and the inside diameter tapers at one end. It is split into four equally spaced pieces parallel to its axis; a circular wedge is machined into the tubing at the tapered end.

The push rod is installed inside the tubing. To produce the spalling effect, the rod is pushed towards the end of the bit, which has been placed into a predrilled hole. The wedges are thus forced radially outward against the walls of the hole. As the push rod approaches the bottom of the drilled hole, it forces the wedges away, spalling a 5-cm deep crater (Smith, Konzek, and Kennedy 1978).

The initial drilling of the hole is the single most time-consuming portion of the process. Holes are most effectively drilled in a triangular pattern on $20-\mathrm{cm}$ centers, and each hole can be expected to take about 10 to $15 \mathrm{sec}$ using a compressed air drill. On this basis it will take about $10 \mathrm{~min} / \mathrm{m}^{2}\left(\sim 1 \mathrm{~min} / \mathrm{ft}^{2}\right)$ to drill and spall a concrete surface (Halter and Sullivan 1980a; Halter and Sullivan 1980b).

\section{Flame Spalling}

This technique uses heat-induced differential expansion to scale as much as an inch of material from concrete surfaces. A high-temperature flame is slowly passed on the order of $60 \mathrm{~min} / \mathrm{m}^{2}\left(5 \mathrm{~min} / \mathrm{ft}^{2}\right)$ over the surface, producing small particles of dust and rubble (Halter and Sullivan 1980a; Halter and Sullivan 1980b). A relatively large air filtration system is required to prevent airborne contamination from spreading. No actual decontamination tests have been performed.

\section{Scarifier}

The scarifier is a tool composed of multiple air-operated piston heads, each of which is faced with five-point or nine-point tungsten carbide bits. It 


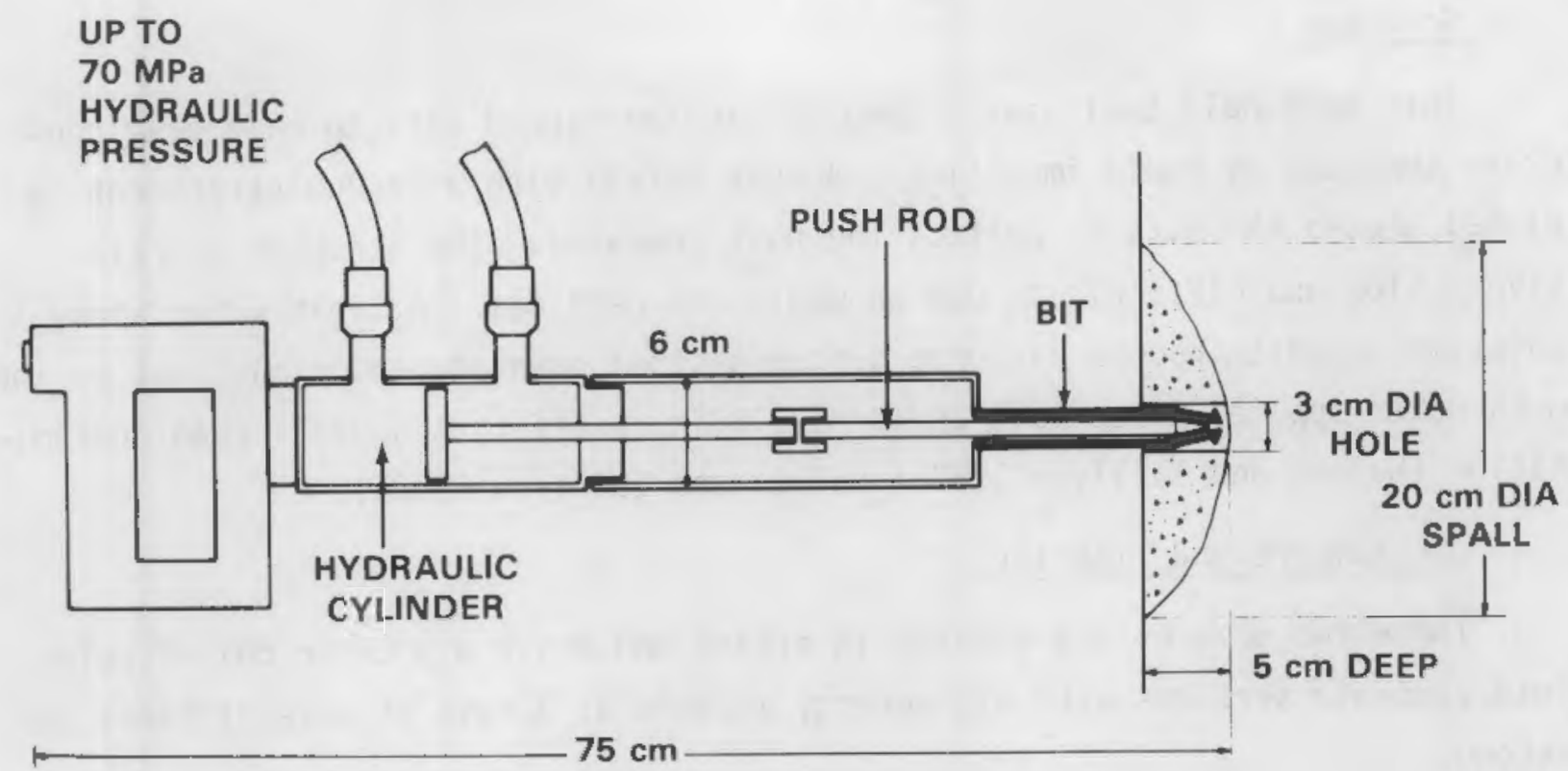

FIGURE 4. Schematic of Concrete Spaller

is effective on walls and floors when used in conjunction with a highefficiency particulate air (HEPA)-filtered vacuum system to contain contaminated dust at the source. A seven-piston floor unit is capable of removing up to $10 \mathrm{~min} / \mathrm{m}^{2}$ ( $1 \mathrm{~min} / \mathrm{ft}^{2}$ ) of surface concrete to a depth of $5 \mathrm{~cm}(1 \mathrm{in.})$ (Manion 1980).

\section{Water Cannon}

The term water cannon describes two types of high-pressure jet spalling devices. One is a hand-held, modified 0.458 magnum smoothbore gun that fires glycerine capsules at close range onto the contaminated concrete surface. Cleanup is facilitated by a glycerine coating around all of the rubble produced, which contains not only the original contaminated concrete but also gunpowder combustion products. The process is relatively slow, running around $1 \mathrm{~m}^{2} / \mathrm{hr}\left(0.2 \mathrm{ft}^{2} / \mathrm{min}\right)$ of surface removed.

The second type of water cannon is a compressed gas-actuated piston that forces small bursts of water at high velocities through a nozzle at up to five shots per second. Typically, it is mounted on a heavy piece of equipment such as a back hoe. Spalling rates are on the order of $2.5 \mathrm{hr} / \mathrm{m}^{2}\left(0.25 \mathrm{hr} / \mathrm{ft}^{2}\right)$ (Beitel and Schlienger 1978). The experience reported is based on laboratory tests or on cured concrete plates (Platt 1975). 


\section{Scrubber}

This hand-held tool uses a gang of carbide-tipped bits to chip away concrete surfaces by rapid impaction. A dust shield with a vacuum attachment is placed around the bits to collect the dust produced. The scrubber is relatively slow and difficult to use on walls and ceilings. A light water spray is sometimes used to reduce airborne contamination; however, there must not be too much water applied since this could result in runoff that would spread contamination (Halter and Sullivan 1980a; Halter and Sullivan 1980b).

\section{Jackhammers and Impactors}

These two devices are similar in effect and drive a pick or chisel point into concrete surfaces with high-energy impacts at a rate of several times per second.

Compressed air-powered jackhammers are readily available and easily used by one man; however, they are primarily used on floors because they are heavy and hard to maneuver. Impactors are more appropriate for removing contaminated concrete wall and ceiling material. Impactors are powered by air or hydraulics and are positioned with linkages similar to those found on tractormounted back hoes and excavators (Ureda 1976; Halter and Sullivan 1980a; Halter and Sullivan 1980b).

\section{Explosives}

Explosives can be used for surface removal with excellent control of both the amount of material removed and the extent of airborne contamination.

The first stage of concrete surface removal by explosives is to drill holes to hold the charges. Constrained by the shape of the wall and thickness of the concrete, these holes may be drilled parallel to and about $130 \mathrm{~mm}$ (5 in.) from the surface, outside of any reinforcing steel. When the entire length of the surface to be removed is drilled, explosives are inserted in the holes and backfilled with sand, if necessary, to produce the desired amount of surface removal. When it is physically impossible to drill holes parallel to the surface, they may be drilled perpendicular on $300-\mathrm{mm}(1-\mathrm{ft})$ centers over 
the entire surface; each hole should be $130 \mathrm{~mm}$ ( 5 in.) deep. After the explosives are inserted, the holes are sealed with mortar.

Blasting mats and water spray are used to contain the dust and flying debris accompanying the explosion. The blasting mats are roughly $3 \times 4 \mathrm{~m}$ and weigh $1600 \mathrm{~kg}(10 \times 12 \mathrm{ft}, 3500 \mathrm{lb})$. Water is sprayed from $1 \mathrm{~min}$ before to 15 min after the explosion.

Blasting sequences must be such that air pressure surges are minimized. After blasting, the air filtering systems should be checked to verify that they have not been damaged.

Strands of blasting cord twisted together and placed on a tube inserted in the hole are reported to be effective as are partial sticks of dynamite. Liquid explosives have been used where it is difficult to insert solids.

There are several types of explosives in common use for concrete removal, including:

- pentaerytritol tetranitrate (PETN) in the form of detonating cord This is primarily used to blast bore holes up to $\sim 5 \mathrm{~m}(16 \mathrm{ft})$ in depth and to spall surfaces down to about $200 \mathrm{~mm}$ ( 8 in.).

- high-velocity gelatin dynamite (85\%) - Shallow holes ranging in depth from about 0.45 to $1.5 \mathrm{~m}$ (18 in. to $5 \mathrm{ft}$ ) are effectively broken out with this material, which is used when a concentration of energy is needed in a particular area.

- cast TNT - This explosive gives a large amount of fragmentation with less heaving effect than dynamite.

- liquid explosive - This can be used to spall surfaces and make shaped charges.

- water gel explosive - This material is best used where a larger sized rubble is desired and no reinforcing bar is present. It contains a large amount of aluminum and is often used as a partial replacement for the 85\% dynamite (Smith, Konzek, and Kennedy 1978; Halter and Sullivan 1980a; Halter and Sullivan 1980b). 
Explosives are also excellent choices when it is necessary to section large structures. Anderson (1980) provides an excellent summary of these techniques. Although all the techniques described in the Anderson report require expertise in application, the use of explosives is one case where only an expert should be used.

\section{Abrasive Blasting}

An abrasive material--such as sand, $\mathrm{Al}_{2} \mathrm{O}_{3}, \mathrm{~B}_{2} \mathrm{O}_{3}$, glass beads, or magnetite grit--is propelled against the contaminated surface at high velocity to remove activity and some of the substrate. By varying the size and conditions of application, the surface can be scoured, polished, or peened (Spencer 1980). The usual size for effective wet blasting is 60 to 5000 mesh (Spencer 1980); larger particles will cause faster surface removal (Remark 1978).

There is no single technique or abrasive material that is universally applicable. The construction material, type of contamination, extent of decontamination desired, and complexity of the surface must all be considered. Voids smaller than the abrasive are not cleaned effectively unless enough material is removed to enlarge the opening. Steel and concrete are usually sandblasted with pressures of 0.4 to $0.45 \mathrm{MPa}$ ( 80 to $90 \mathrm{psig}$ ).

Dry blasting with sand propelled by compressed air is the most widely used technique industrially. Dust is a problem with this technique, which can be of critical importance in decontamination; therefore, most emphasis lies in wet blasting for decontamination applications.

Wet blasting techniques maintain fine finishes while providing enough action for effective decontamination. In the wet process, sand is mixed with water and propelled by air. Two disadvantages are apparent in the wet technique: 1) the waste water as well as the sand must be retained and monitored prior to disposal and 2) fine sand particles that are formed by destruction of the abrasive are wet and adhere to the surface being cleaned. Of ten this residue must be removed by brushing with a vacuum. Clearly, though, airborne particulates are reduced. 
DFs on exposed smooth surfaces of contaminated laboratory equipment will range from 10 to 50 (Halter and Sullivan 1980a; Smith, Konzek, and Kennedy 1978; Hill 1970).

Steam generator head decontaminations attempted at Gena and Sena using this technique have had limited success (Remark 1978). A major problem in a steam generator water box decontamination is that although the local DF may be high the exposure DF may be low due to shine from nearby sources.

Metal removal in the metals finishing business can be held down to 0.1 mil (Spencer 1980). In mechanical decontamination processes it normally runs higher--about 5 mils.

A technique using carbon dioxide pellets as the abrasive media has been tested and is reported to be somewhat slower than sand blasting (Halter and Sullivan 1980b).

\section{Vibratory Finishing}

Vibratory finishing is a process that uses the scouring action of vibrating abrasive media to remove burrs and prepare surfaces for further treatment (Hignett 1980). It is also useful for the removal of gross contamination when it is unnecessary to obtain complete decontamination of the part.

The use of steel media with sodium hydroxide as the cleaning compound effectively reduces contamination levels on plutonium-contaminated glass and uranium-contaminated molybdenum. DFs range from around 20 down to nonsmearable levels (Arrowsmith and Allen 1978; Platt and Powell 1980; Allen, Arrowsmith, and McCoy 1980).

\section{Ultrasonic Cleaning}

Use of an ultrasonic effect in a soaking bath improves decontamination efficiency by providing vigorous agitation and imparting a physical force at the surface of the work. Agitation keeps fresh solution supplied to all parts of the surface material being cleaned. It is important to use as efficient a soak bath as possible because the ultrasonic action will not necessarily decontaminate a surface effectively in its own right. For example, a detergent solution will not remove high-temperature oxide film from stainless steel, even 
with ultrasonics. If the condition of the surface is of little regard at the end of the decontamination process, exposure time and power can be increased to improve the DF and processing time. However, increased power may cause pitting of the surface.

An ultrasonic facility consists of three principal elements:

- the generator, which converts low-frequency alternating current to high-frequency current

- the transducer, which produces the ultrasonic waves

- the tank, which contains the bath and the contaminated piece.

Vibrations are generated by supplying an alternating current to cause changes in dimension by either ferromagnetic or piezoelectric phenomena. The vibrator may be an electrostrictive or a magnetostrictive transducer. This transducer, placed either in solution or bonded to the tank, generates vibrations in the fluid with a frequency greater than the upper limit of audible sound ( 16 to $20 \mathrm{kHz}$ ). These vibrations cause waves of alternating high and low pressures. At the low-pressure cycle, small bubbles form on the contaminated surface that collapse with enormous force during the following high-pressure cycle. Some reports indicate that pressures may be as high as 10,000 psi and temperatures up to $11000^{\circ} \mathrm{C}$ (Ayres 1971). These conditions are transient and last on the order of microseconds.

From reports published to date, it is not yet possible to state the optimum frequency, temperature, power, time, dimensions, geometry, and bath composition for an ultrasonic bath. The range of interest for ultrasonic cleaning is 20 to $100 \mathrm{kHz}$; but because power requirements increase rapidly above $50 \mathrm{kHz}$, the 20 to $50 \mathrm{kHz}$ range is more common with $40 \mathrm{kHz}$ being a typical industrial value (Geckle 1980). However, good effectiveness has been achieved with frequencies down to 20 to $22 \mathrm{kHz}$, temperatures at 15 to $20^{\circ} \mathrm{C}$ below the boiling point, and power well above the threshold for cavitation (Platt and Powell 1980; Ayres 1971). As noted by Geckle (1980) the audible component at these lower frequencies can be extreme, causing serious health problems. 
The threshold for cavitation is a function of the liquid being used, frequency, and temperature. For water, the threshold of cavitation is $0.39 \mathrm{~W} / \mathrm{cm}^{2}$ $\left(2.5 \mathrm{~W} / \mathrm{in} .^{2}\right)$ at $20 \mathrm{kHz}$ and room temperature. The average power intensity throughout the bath is determined by dividing the average power of the transducer by the tank cross section (Ayres 1971).

Tanks and baskets containing the transducers, solution, and material to be decontaminated are preferably constructed of some hard material such as metal or glass because soft materials absorb energy. Glass is more efficient than metal.

Manion (1980) reports DFs from 2 to 200 but provides no details or references. Ayres (1971) reports that a two-step process using AP and NT-600 (an undefined proprietary compound) in an ultrasonic bath cleaned 3 to 4 times faster than without the ultrasonics. Insufficient data are available to provide exact information on DF improvement, but it is estimated to be several orders of magnitude.

\section{Liquid Honing}

In the metal finishing industry, liquid honing is used to clean surfaces prior to electroplating, remove burrs, and reduce internal stresses (Spencer 1980). In the nuclear industry it has been used on components contaminated with beta and gamma fission products to achieve DFs of around 11 on rubber and 100 on mild steel in 5 min or less. The liquid honing process combines a liquid containing 30 vol\% abrasive particles with a stream of air at $0.5 \mathrm{MPa}$ (100 psi). This abrasive mixture is propelled against the surface to be cleaned by a hand-held gun. Typical surface removal is around $0.01 \mathrm{~mm}$ (0.4 mils) (Arrowsmith and Allen 1978).

\section{Strippable Coatings}

Strippable coatings consist of plastic membranes such as polyethylene, caseins, and polyvinyl chloride (the latter are carcinogenic and have low threshold limit values). They are used both as protective coverings to prevent contamination of the permanent surface and as a means of removing contamination from surfaces (Bernaola and Filevich 1970). The coatings are best applied by brush, and two or more coats are usually necessary to insure that the material 
has sufficient tensile strength to be removed from the surface. Bonding to most substrates is in the 0.01 to $0.07 \mathrm{MPa}$ (2 to $10 \mathrm{psi}$ ) range while the tensile strength of a dry layer ranges from 0.5 to $1.5 \mathrm{MPa}$ (100 to $300 \mathrm{psi}$ ). Curing occurs within $24 \mathrm{hr}$. Some advantages of this technique are high DFs for smearable activity (see Table 4), proven technology, and readily available equipment. Disadvantages include the possibility for high man-rem exposure during application and removal, undetermined DFs for tight oxide layers, time consuming, and the presence of chlorides and fluorides in some coatings [Imperial(a) 1976; Bernaola and Filevich 1970]. Coatings left in place for extended periods are often difficult to remove. Frequently, a single layer of cheese cloth set underneath the coating will alleviate this problem. Strippable coatings are also helpful in protecting surfaces during processes that may lead to contamination.

\section{Water/Steam Jet (Hydrolazing)}

Contamination present in loose scale or crud can be removed by a water spray at very high pressure. Jets delivering water or steam at 2 to $70 \mathrm{MPa}$ (400 to 14,000 psi) are capable of removing smearable contamination with overall DFs ranging from 3 to 50 (Combs et a1. 1980; Ayres 1971). If pressures of 50 to $280 \mathrm{MPa}(10,000$ to $56,000 \mathrm{psi})$ are used, concrete can be cut (Halaris and Bortz 1980; Combs et al. 1980). This method generates a large amount of liquid waste, but it may be possible to recirculate and reuse the water since no chemicals are used. Flows are generally 40 to $2001 / \mathrm{min}$ (10 to $50 \mathrm{gal} / \mathrm{min}$ ). The equipment for this technique is readily available, and vendors can be brought in to do the job.

Advantages of the process include proven usefulness for smearable activity, remote handling capability, and low man-rem exposure if remotely operated. Disadvantages include high waste volumes, hazards because of high pressures, high man-rem exposure if manually operated, and potential for driving contamination further into the surface (concrete) (Ayres 1971; Halaris and Bortz 1980; Combs et al. 1980).

(a) Imperial Professional Coatings Corp., New Or leans, Louisiana. 
TABLE 4. Decontamination of Different Surfaces with a Single Application of Coating(a)

$\begin{array}{lc}\text { Material } & \begin{array}{c}\text { Decontamination } \\ \text { Factor }\end{array} \\ \text { Stainless Steel } & 100 \\ \text { Glass } & 100 \\ \text { Formica } & 100 \\ \text { Glazed Tiles } & 25 \\ \text { Granite Mosaic } & 14 \\ \text { Calcareous Paving Tile } & 11 \\ \text { Tile Joints } & 10 \\ \text { Smooth Concrete } & 8 \\ \text { Rough Concrete } & 2.6 \\ \text { Smooth Wood (pine) } & 2.9 \\ \text { Brick } & 1.7\end{array}$

(a) Coating was solution of copolymers of polyvinyl chloride ( 83 to $85 \%$ ) and vinyl acetate (15 to $17 \%$ ) with additives in the solvent; hardened in 3 min and reached required properties in $2 \mathrm{hr}$ (Bernaola and Filevich 1970).

Vacuum (Wet or Dry)

This technique is sometimes useful on contamination from airborne deposition that has not adhered strongly to the surface or from gross spills. Suitable filters must be placed over the exhaust to prevent resuspension of the contamination. The primary advantage of the process is the speed with which it can be applied. As would be expected, DFs range from good on hard, nonporous surfaces to poor on porous ones (White and Dunaway 1975).

Sectioning

Although sectioning is not strictly a decontamination method, it is a potential first step in component decontamination. Sectioning is required when one of several conditions occur: 
- the interior of the structure is contaminated by neutron activation or diffusion from the exterior

- the structure cannot be cleaned in place due to access restrictions

- economics do not favor decontamination.

Plasma Arc Torch. Plasma arc cutting uses an extremely high-temperature, high-velocity gas arc between an electrode and the piece to be cut. The process can be used on any metal. The arc is produced when the gas passes through a nozzle with a small diameter orifice. Standard-duty cutting requires voltage supplies of 120 to $240 \mathrm{~V}$; heavier materials--up to $5 \mathrm{~cm}$ (2 in.)--require up to $400 \mathrm{~V}$. The intense heat produced by this localized energy melts the metal and produces a high-quality saw-like cut. If an inert gas is used, the cutting action depends on the heat alone. Cutting gases containing oxygen can markedly increase the cutting speed on materials such as mild steel and cast iron. The chemical energy obtained by the combination of oxygen with the base metal is added to the arc heat to permit higher cutting speeds. Stainless steel, aluminum, and other nonferrous metals are usually cut with a mixture of argon and hydrogen or nitrogen and hydrogen. Carbon steel, cast iron, and alloy steels are cut with nitrogen and oxygen, supplied separately to the torch and mixed in the nozzle.

The equipment used is largely the same as that for gas tungsten-arc welding except that an electrical lead is taken from the ground and passed through a resistor to the nozzle of the torch. The circuit between the nozzle and the electrode is completed by a high-frequency spark, producing a pilot arc that initiates the main arc from the electrode to the work piece.

The plasma cutting process can be used in air or underwater, and it is adaptable to automation and to the piercing and cutting of holes in large plates and vessels (Smith, Konzek, and Kennedy 1978; Wehmann et al. 1975).

Arc Saw. The arc saw is reported to be an efficient and cost-effective means of sectioning metal components prior to decontamination for decommissioning. By modifying commercially available standard equipment, a prototype saw has been built to rotate a $1-m(36-i n$.$) diameter, 6-m m(1 / 4-i n$.$) thick copper$ 
or mild steel blade with an 11.2-KW (15-hp) motor. Blade speed is approximately $880 \mathrm{rpm}$ with cooling by a water spray installed in the blade guard. The power source is modified to provide dc power at $7500 \mathrm{~A}$ and $80 \mathrm{~V}$ open circuit. This low-voltage, high-amperage current passes through the arc saw blade to the grounded work piece, melting the base metal while producing a narrow kerf.

A variety of metal types and shapes can be cut without binding because any shift in the work piece causes a shift in the electrical leading edge of the blade; in other words, the current that was formerly passing from the narrow tip of the blade to the work piece temporarily shifts to the side of the blade. The result is a momentary slowing of the cutting speed and the cutting of a wider kerf to accommodate the shifting.

A material cut-to-blade wear factor of 20 to 1 has been reported. It is anticipated that by increasing biade diameters to 2 to $3 \mathrm{~m}(6 \mathrm{to} 10 \mathrm{ft})$ larger diameter stock will be serviceable and blade wear ratios and associated costs will be reduced (Smith, Konzek, and Kennedy 1978). This equipment has been tested only under laboratory conditions on nonradioactive material (Beitel and Schlienger 1976).

Flame Cutting. Flame cutting is an established process using commercially available $3-\mathrm{m}$ long by $19-\mathrm{mm}$ diameter (10-ft by $3 / 4-\mathrm{in.}$ ) thin-walled conduit burning bars. Each bar may contain up to seven dissimilar metals in the form of strands and is encased in an outer tube into which oxygen is forced during the burning process. The complete rod is consumed as it burns. When there is about $0.5 \mathrm{~m}$ (20 in.) left, the oxygen supply is shut off and the reaction stops. The remaining section of the first bar can be attached to a second bar and the burning process continued, thus minimizing material waste.

Advantages of this procedure include the capability of remote operation, fast cutting, adaptability to irregular surfaces, and a controlled rate of material removal. Disadvantages include the production of toxic gases and smoke, large gas consumption, potential for spreading gross contamination via 
the smoke, and the requirement of a through starter hole made by a core drill to provide an outlet gas flow path [UPA (a) 1974; Smith, Konzek, and Kennedy 1978].

Thermic Lance. This device can be hand held or remotely operated and uses powders of materials that are similar to the strands of the burning bar. The powders are forced through a tube or nozzle with oxygen and ignited to form a high-temperature cutting medium.

Advantages of this process include fast hole punching speed, ability to cut both concrete and steel, adaptability to irregular surfaces, and a controlled rate of material removal. Disadvantages include the production of smoke and toxic gases, the need for a rock jack to break away cut concrete sections, consumption of large amounts of bottled oxygen, and the possibility that the smoke will spread gross contamination (UPA 1974).

Shear/Punch. A heavy-duty double-cut hydraulic shear/punch has been used to cut $25-\mathrm{cm}(9-\mathrm{in}$.$) wide strips of 0.5-\mathrm{cm}\left(1 / 4-i\right.$. $_{\text {. }}$ stainless steel or $1-\mathrm{cm}$ (3/8-in.) mild steel (Platt and Powell 1980). No cutting waste is produced since the kerf material is $0.5-\mathrm{cm}$ (1/4-in.) strips that can be decontaminated by some other means, and there is very little entrainment of surface contamination on the sheared edge. The typical cycle time for each cut with this system is $10 \mathrm{sec}$. Accordingly, if the cut material is to be $25 \times 15 \mathrm{~cm}(9 \times 6$ in.), then 1 linear $m$ ( 3 linear $\mathrm{ft}$ ) of $25 \mathrm{-cm}(9-\mathrm{in}$.$) wide strips or 0.75 \mathrm{~m}^{2}$ $\left(2.25 \mathrm{ft}^{2}\right)$ of material can be sectioned per minute. A clear disadvantage of the system is that it can handle stock no larger than $25 \mathrm{~cm}$; larger material must be sectioned by some other means.

Radioactive testing of the equipment has been performed by sectioning strips of stainless steel from plutonium-contaminated glove boxes (Platt and Powe11 1980).

(a) United Power Association, Elk River, Minnesota. 
Negative Rake Cutting. A circular saw blade specifically designed for cutting Plexiglas ${ }^{\circledR}$ has been developed (Platt and Powell 1980). The desirable feature of this blade is its negative rake that cuts while preventing material from loading onto the teeth of the blade. Under normal working conditions for contaminated material, 3 to $5 \mathrm{~m} / \mathrm{min}$ of $1-\mathrm{cm}(3 / 8-\mathrm{in}$.$) Plexiglas can be cut.$

Core Boring. This technique uses a diamond-tipped core drill similar to that used in conventional mining operations. Its use is feasible for the removal of concrete walls up to $0.6 \mathrm{~m}(2 \mathrm{ft})$ thick. The process has been successfully used in the laboratory portion of this program to obtain samples from various reactors for decontamination. As part of the same program, a metal hole is now being used to take samples from selected pipe specimens.

Disadvantages of this method include uneconomically slow concrete removal and the need to collect and decontaminate cooling water (UPA 1974).

Melting. Melting metal components provides a possible means of decontamination if the contamination is either not soluble in the molten metal or more soluble in the slag (Dillon et al. 1976; Ayres 1970). PNL has studied an Inductoslag process for reducing the volume of fuel cladding hulls (Nelson and Montgomery 1980; Dillon et al. 1976) that uses induction heating to melt the metal, e.g., Zircaloy or stainless steel. Hulls are fed continuously in the top and a solidified product mass is extracted from the bottom. Dillon et al. (1976) note the possibility of metal decontamination during the melting process.

One tested application is the decontamination of lead (Ayres 1970). The process destroys the shape of the material but ultimately causes only a $2 \%$ material loss for essentially complete decontamination. The lead is heated to $400^{\circ} \mathrm{C}$, a mixture of high melting minerals (e.g., $\mathrm{Al}_{2} \mathrm{O}_{3}, 30 \%$; $\mathrm{SiO}_{2}, 30 \%$; $\mathrm{Ca} 0,40 \%)$ is added, and this temperature is maintained for $20 \mathrm{~min}$. At the end of the process the slag is scraped off and discarded to radioactive waste.

\footnotetext{
- Registered trademark of the Rohm and Haas Company, Philadelphia, Pennsylvania.
} 
Since there is some danger of atmospheric contamination with this process, the furnace must be vented and filtered before release to the atmosphere (Ayres 1970).

Soil Decontamination. Because soil decontamination is a considerably different process from other methods of decontamination, the techniques used will be grouped here rather than as separate processes. As with other "structures," soil can be either removed or decontaminated. In the latter case, the decontamination probably would be done in a vessel rather than in situ although there may be electrochemical processes that might be applicable to in situ decontamination.

Ayres (1970) describes many examples of and procedures for immediate responses to unexpected contamination, including vacuuming, flushing, and coating; dilution, by plowing the activity under, is also discussed. However, these methods are not acceptable for decominissioning purposes. Similar procedures are described by White and Dunaway (1975).

Lindsay, Michels, and Martinez (1973) describe an actual soil decontamination at the Rocky Flats Plant, Golden, Colorado, using polyurethane foam. An area of about $4 \mathrm{~m}^{2}$ was coated with a $5-\mathrm{cm}$ deep layer of foam; after it set, the dried foam and $85 \%$ of the activity was removed.

Excavation and removal of the soil to an approved burial site has its analogies with various sectioning processes described above, and this process has been used for many years (Horan and Cunningham 1971; 01sen et a1. 1980; White and Dunaway 1975). With care, all of the radioactive contaminant can be cleaned up if the activity does not penetrate too deeply. However, the waste volume will be large and airborne contamination can be a problem.

In view of the large waste volume, Rocky Flats personnel have been experimenting with selective decontamination (01sen et al. 1980). Their work has been with wet screening, attrition scrubbing at high and low $\mathrm{pH}$, and cationic flotation; no results have been presented for the cationic flotation. Wet screening consists of screening the wet soil adjusted to greater than $\mathrm{pH} 11$ with $\mathrm{NaOH}$. In a test of soil contaminated with plutonium and americium, $76 \%$ of 
the soil finer than 35 mesh had $99.9 \%$ of the activity removed. The remaining $24 \%$ of the soil contained the balance of the activity with some being present in the waste solution.

Attrition scrubbing is essentially autogenous grinding in a mill with $\mathrm{pH}-$ adjusted water. When the $\mathrm{pH}$ was adjusted to a high (unstated) value, $99.9 \%$ of the activity after four cycles remained with the fines that constituted $20 \%$ of the original soil.

A low pH solution (Table A.1, Nos. 120-122) was used to wash/scrub the soil five times; the fines and the wash solution contained well over $99.9 \%$ of the original activity. There is the theoretical possibility of decontaminating a large area biologically by cultivating and harvesting crops known to concentrate a particular element. Loco weed, for instance, will selectively concentrate selenium from soil; however, as yet, no practical application has been found for this technique. A polyurethane foam that cures to a solid has been used for stabilizing contaminated soils and is reported to have a high capacity for picking up contamination at a relatively low cost (Lindsay, Michels, and Martinez 1973).

\section{ELECTROCHEMICAL DECONTAMINATION METHODS}

Electrochemical decontamination methods have the advantage of being fast and easily controlled. Various processes have been in existence and used in industry for many years (Jumer 1980; DeBarr and 0liver 1968); they have also been used in metallurgy and the chemical laboratory. In recent years interest has developed in the use of electrochemical methods, particularly electropolishing, for decontamination.

\section{Electropolishing}

Surface-contaminated metals from nuclear facilities can of ten be rapidly decontaminated to unrestricted release conditions by electropolishing. For example, SS tools contaminated with plutonium oxide have been reduced from more than 1 million dis/min-100 $\mathrm{cm}^{2}$ to background in less than 10 min (Arrowsmith and Allen 1978). 
In this process, the object to be decontaminated serves as the anode in an electrolytic cell (see Figure 5) (Allen, Arrowsmith, and Budke 1978). Within a certain range of voltage to current density there occurs a progressive dissolution of the surface material. If the voltages and current densities are too low, the surface is attacked nonuniformly, causing etching rather than polishing; voltages that are too high cause severe pitting of the surface (see Figure 6). Radioactive material that is on the surface or entrapped in surface imperfections is removed and released into the electrolyte. Typically less than $0.05 \mathrm{~mm}$ ( $2 \mathrm{mils}$ ) of material are removed with one treatment.

Operating conditions using a phosphoric acid electrolyte typically have solution temperatures of 40 to $80^{\circ} \mathrm{C}$, concentrations of 40 to $80 \%$, electrode potentials of 8 to $12 \mathrm{~V}(\mathrm{dc})$, current densities of 50 to $500 \mathrm{~A}_{\mathrm{ft}}{ }^{2}$, and time intervals of 5 to 30 min (Jumer 1980; Allen, Arrowsmith, and Budke 1978). Hydrogen evolved from this process may require venting.

Electropolishing tanks are constructed of stainless steel because they can be decontaminated by making the walls anodic. Support equipment for an electropolishing system includes a dc power supply, rinse tanks, a ventilation system, and a means of temperature control and mixing of the solutions.

In situ electropolishing is being developed for use on those components that cannot be immersed in a typical electropolishing cell. This capability should be especially useful in decommissioning work to decontaminate tanks, large process equipment pipe interiors, or other large metallic surfaces prior to dismantling. Contact in situ electropolishing consists of an insulated unit holding the cathode at a fixed distance from the anodic surface to be decontaminated. Electrolyte is pumped through the unit at a slight negative pressure; a test unit is reported to decontaminate $20 \mathrm{~cm}^{2}\left(3 \mathrm{in.}^{2}\right)$ of stainless steel in 5 min using a phosphoric-sulfuric electrolyte at a current density of $550 \mathrm{~A} / \mathrm{ft}^{2}$ and a potential of less than $12 \mathrm{~V}$ (dc) (Allen, Arrowsmith, and Budke 1978). 


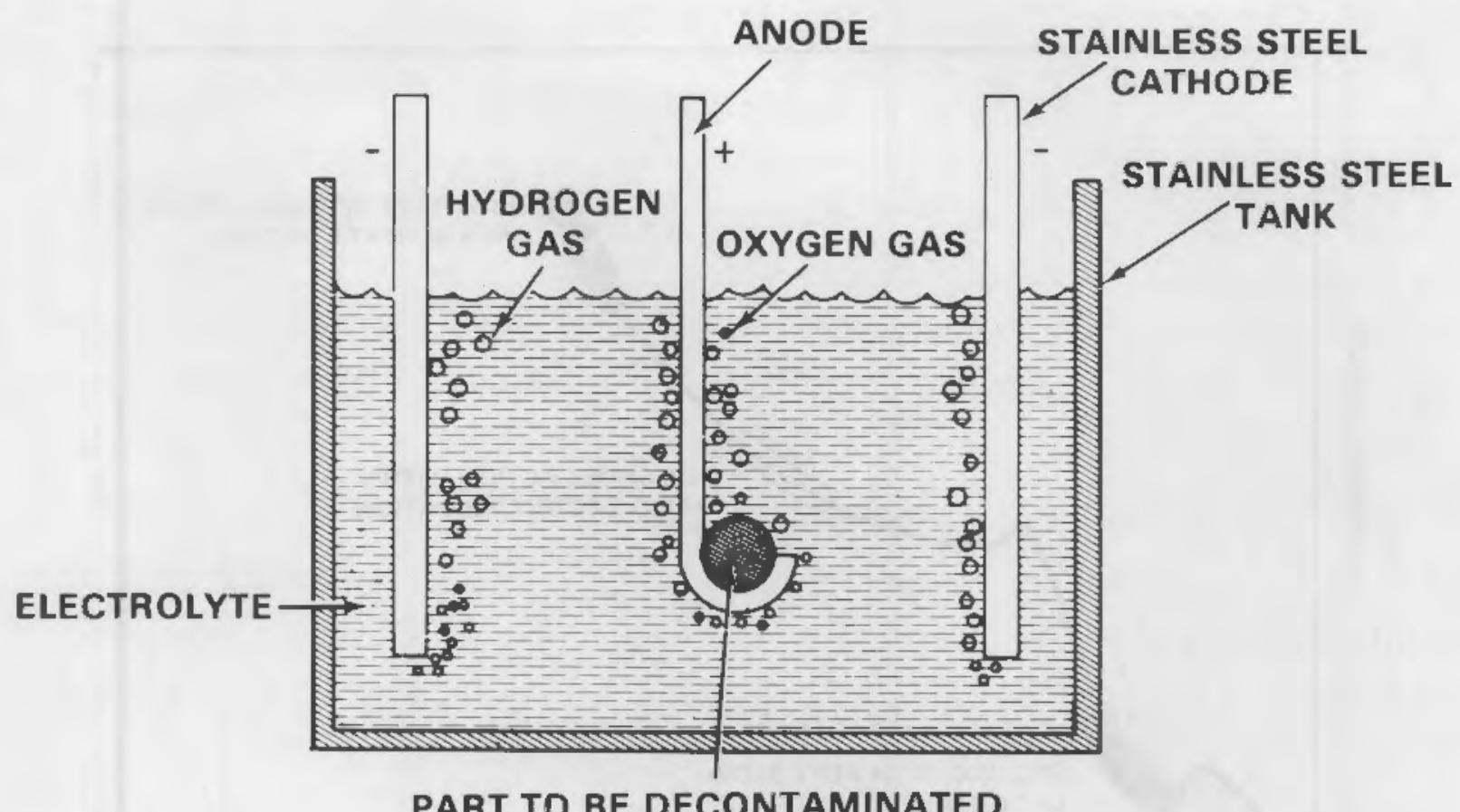

FIGURE 5. Schematic of the Type of Electropolishing Cell Used to Decontaminate Metal Surfaces

Pumped stream electropolishing, where the cathode is the pipe nozzle, has been developed to the point where a 1.3-cm (0.5-in.) diameter stream of phosphoric acid electrolyte conducting a current of $2 \mathrm{~A}$ can reduce the radiation level on a plutonium-contaminated carbon steel component--the anode--from $15,000 \mathrm{dis} / \mathrm{min}-100 \mathrm{~cm}^{2}$ to background in less than $2 \mathrm{~min}$.

\section{Electrobrushing}

Electrobrushing is an electropolishing process on selected areas. The component to be decontaminated is the anode while the electrobrush serves as the cathode. The brush itself is a cellulose sponge wetted by a continuous feed of an electrolyte such as 5\% sulfuric acid solution inhibited with $1 \mathrm{~g} / 1$ ethylquinolinlium. Decontamination is by scrubbing at a current of 15 to $40 \mathrm{~A}$ at 15 to $20 \mathrm{~V}$, and DFs of around 30 are reported at a rate of $0.6 \mathrm{~m}^{2} / \mathrm{hr}$ (6 $\mathrm{ft}^{2} / \mathrm{hr}$ ). 


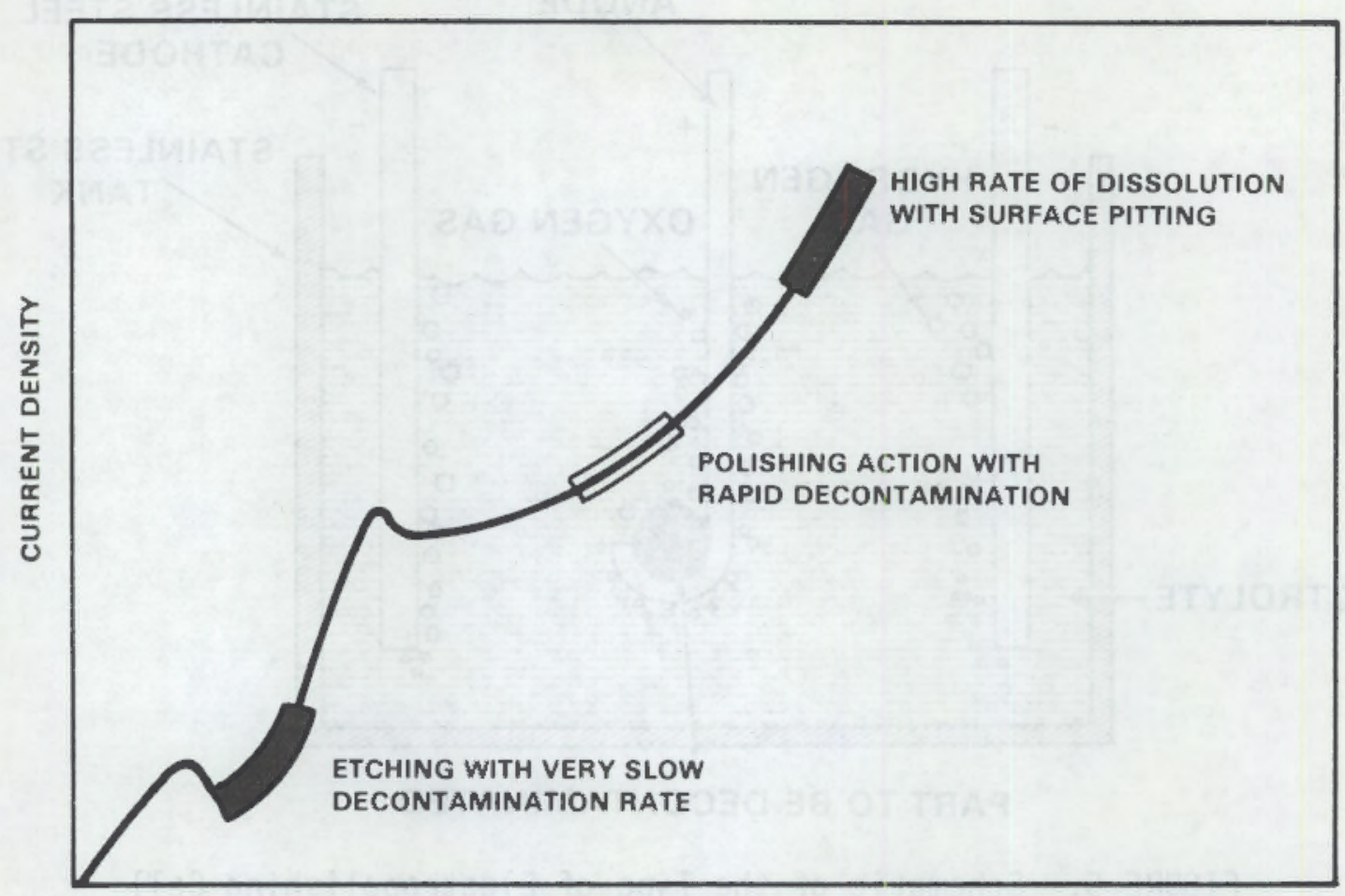

CELL VOLTAGE

FIGURE 6. Relationship of Current Density and Cell Voltage for Electropolishing Showing Optimum Operating Region for Electrochemical Decontamination

Some advantages of this system are in situ capability, high DFs, proven usefulness on PWR films, and readily available equipment. Because the process removes base metal and because of the experience by Allen, Arrowsmith, and Budke (1978) and Arrowsmith and Allen (1978), the process is also expected to be quite applicable to BWR systems. Disadvantages of the system include the production of large volumes of aqueous radioactive waste and excessive attack of the surface by the electrolyte; in addition, if the decontamination is performed manually rather than remotely, the man-rem exposure may be high.

\section{Electrochemical Cutting}

This is a process for electrochemically cutting an irradiated fuel assembly as described in the patent disclosure by Wurm (1972). The fuel assembly serves as the anode while the cutting tool functions as the cathode. The tool itself is connected to the fuel assembly and consists, in part, of a row 
of channels through which electrolyte passes against the assembly. It is equivalent to the industrial process of electrochemical machining (DeBarr and Oliver 1968; Wurm 1972).

The electrolyte consists of a molten salt of alkali nitrate in which a fluoride of the group NaF, KF, and LiF is dissolved in a concentration of 1 to $10 \mathrm{~mol} \%$.

\section{Molten Salt Descaling}

Molten salt descaling has not, to the authors' knowledge, been used for decontamination. It is used industrially to remove sealer, paints, and a number of other coatings (Mazia 1980), and there are baths to suit nearly every purpose (see Table 5).

Advantages of all molten salt descaling baths include negligible base metal attack, low viscosity, and excellent wetting (Mazia 1980). The wetting insures that the oxide is rapidly heated upon immersion, which contributes to the detachment of the scale. Final scale removal occurs in a water quench followed by a dilute acid rinse, if needed. Whether these processes affect the metallurgical state of the components (for example, sensitization) will depend on the alloy and the inmersion time.

The electrolytic bath operates in a similar manner but can be electrolytically polarized to oxidize or reduce surface deposits.

\section{Electrodialysis.}

Electrodialysis as described by Grant and Scherpers (1978) is a waste treatment process whereby an aqueous solution containing ionic contaminants is loaded on a mixed bed ion exchange resin in the center compartment of an electrodialysis cell. Electrodes at opposite sides of the cell apply a voltage across the resin, causing cations to migrate through the resin toward the anode and anions to migrate through the resin toward the cathode.

The resin on the anode side of the cell is bordered by an anion-selective membrane, and the anode itself is partitioned off by a cation-selective membrane. In this way, hydrogen ions (actually hydronium ions, $\mathrm{H}_{3} \mathrm{O}^{+}$) generated at the cathode pass through the cation-selective membrane and combine with the 


\section{TABLE 5. Metal Cleaning Salt Baths}

\begin{tabular}{lcc}
\multicolumn{1}{c}{ Type of Salt Bath } & $\begin{array}{c}\text { Operating } \\
\text { Temperature, }{ }^{\circ} \mathrm{C}\end{array}$ \\
\cline { 1 - 1 } High-Temperature Oxidizing & & $450-540$ \\
Intermediate-Temperature Oxidizing & $370-480$ \\
Low-Temperature Oxidizing & $200-220$ \\
Reducing & $370-400$ \\
Reversible Electrolytic (oxidizing reducing) & $440-470$ \\
Paint Stripping (oxidizing with catalysts) & $450-480$ \\
Vitreous Enamel Stripping & $480-510$ \\
Molybdenum and Other Refractory Metal Descaling & $425-450$ \\
Special Purpose Baths & & (a)
\end{tabular}

(a) Temperature depends on application.

anions from the original solution to form a relatively pure acid. In a like manner, concentrated base is generated on the anodic side of the cell. Water that is essentially free of ionic species is generated from the center compartment.

The technique is still under development, and numerous cell configurations with and without ion exchange resins in the various compartments have been used. A similar system has been demonstrated for the treatment of PWR waste streams to recycle lithium as the hydroxide and borate as boric acid. The purity of the effluent produced is sufficient for use as demineralized water.

Energy consumption of liquid waste treatment is reported comparable to evaporation. Capital equipment, space requirements, and labor costs are reported to be less; recycled materials reduce both procurement and waste disposal costs.

Electrodialysis has also shown promise for the leaching of contaminants from porous material (such as chloride from concrete on bridges) and, therefore, will be tested in later phases of this program. Figure 7 shows a 


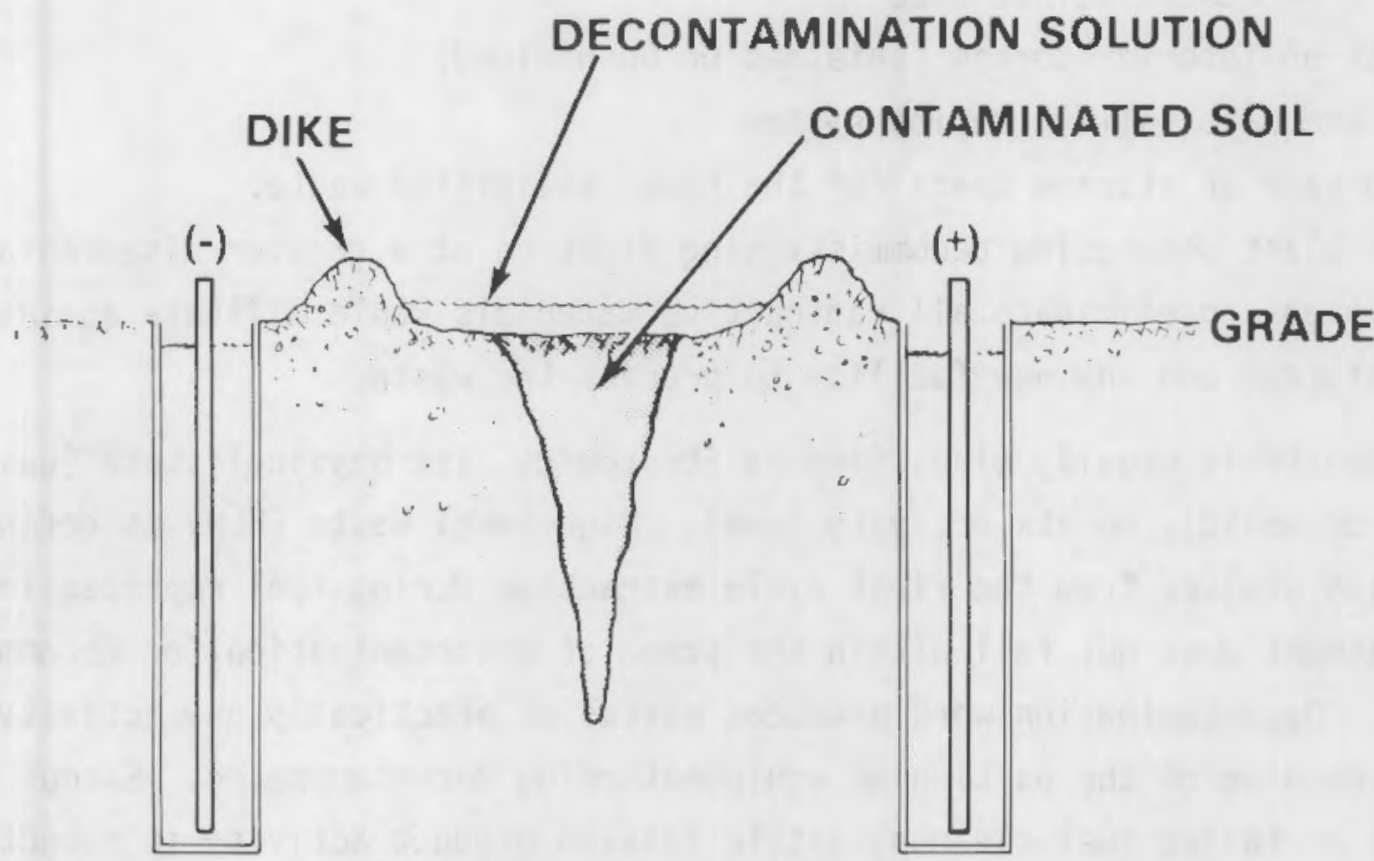

FIGURE 7. Trench Decontamination by Electrodialysis

conceptual process for using electrodialys is to decontaminate soil. There are still problems with leakage between gaskets and semipermeable membranes leading to recontamination of the process stream. The degree of concentration is limited by back diffusion and the solubility of the concentrating salts (IAEA 1964).(a)

\section{RADIOACTIVE WASTE DECONTAMINATION}

A brief review of methods of decontaminating ${ }^{(b)}$ radioactive waste is presented because such wastes are generated during decontamination. One would expect that the radwaste treatment facility at a plant could handle these wastes, but as noted by Perrigo et al. (1979) such capability is unlikely.

(a) International Atomic Energy Agency, Vienna, Austria.

(b) The processes may be viewed as a decontamination of the bulk of the waste or volume reduction of the radioactive fraction. 
The major shortcomings of operating radwaste facilities include one or more of the following:

- lack of remote maintenance

- lack of interim storage (shielded or unshielded)

- no adequate solidification system

- shortage of storage space for the final solidified waste.

An older plant undergoing decommissioning might be at a greater disadvantage because plans to eliminate all radioactive materials would militate against onsite storage and any new facility to process the waste.

Radwaste is usually classified by its source, its physical state (gas, liquid, or solid), or its activity level. High-level waste (HLW) is defined as that which evolves from the first cycle extraction during fuel reprocessing. HLW treatment does not fall within the scope of decontamination for decommissioning. Decontamination work produces wastes of practically any activity level depending on the particular equipment being decontaminated. Except in the case of failed fuel cleanup, little fission product activity is expected.

The intent of this section is to introduce techniques to reduce the volume of solutions that become active in the course of decontamination work. Most decontamination methods involve a liquid stage at some point in the process.

\section{Precipitation}

Many of the active species entrained in decontamination solutions can be removed by precipitation. Methods of this type have been used for treating large volumes of aqueous solutions. Separation of the supernate and the solids can be accomplished by settling, filtration, or centrifugation.

In some cases the contaminants to be removed may already exist as suspended solids, as with liquid wastes from vibratory finishing processes and spent electrolytes from electropolishing. It has been shown that particles as small as 1 micron can be removed by centrifugation. Diluted, neutralized phosphoric acid and spent sodium nitrate electrolytes have both been treated in this way. Polyelectrolytes (polymers of high molecular weights) can of ten be used to increase the effectiveness of the centrifuge. Three of these, all acrylamide copolymers, have been tested to show that the settling rates of 
solids may be accelerated for dilute, neutralized phosphoric acid electrolytes, sodium nitrate electrolytes, and liquid wastes from vibratory finishing using ceramic media. Each polyelectrolyte was effective for a specific waste (Platt and Powell 1980). Those contaminants that remain in solution can be removed by coprecipitation, adsorption of ions on freshly formed precipitates, or floculation of collodial material (IAEA 1964). Methods for the removal of specific ions are outlined below.

Cesium can be coprecipitated in the presence of nickel sulfate $\left(\mathrm{NiSO}_{4}\right)$ or copper sulfate $\left(\mathrm{CuSO}_{4}\right)$ and potassium ferrocyanide $\left[\mathrm{K}_{4} \mathrm{Fe}(\mathrm{CN})_{6}\right]$ in the $\mathrm{pH}$ range of 2 to 10. Introduction of a floculating agent such as ferric hydroxide $\left[\mathrm{Fe}(\mathrm{OH})_{3}\right]$ may be required removal of the precipitate (IAEA 1964; Kol ycher and Sedov 1968).

Calcium and several other polywalent radioactive cations can be removed as their insoluble phosphates in a pH range of 10 to 12 . The amount of phosphate required varies with the nature of the waste solution but is always in excess of the stoichiometric amount.

Radioactive strontium can be removed by coprecipitation with a radiologically stable strontium salt in the presence of excess phosphate ions at a high pH (IAEA 1964; Kolychev and Sedov 1968; Wiley 1976).

Rare earths and some alpha emitters can be floculated by the introduction of ferric or ferrous salts and regulation of the $\mathrm{pH}$.

Solutions containing a variety of radionuclides can sometimes be decontaminated by the simultaneous addition of several precipitating agents. Sometimes, however, this is impossible because of the need to adjust $\mathrm{pH}$ to a different optimum level for each contaminant radionuclide.

Mixtures of several polyvalent cations can be decontaminated by adding trisodium phosphate and a ferric salt at a pH of 10 to 11 (IAEA 1964).

Iodine has been removed very effectively from aqueous solutions by use of hydrated ferric oxides activated by silver ions (Malasek 1967). 


\section{Filtration}

Many waste treatment techniques, such as precipitation, produce a sludge that must be separated from the decontaminated solution; filtration has been used to accomplish this. Gravity filtration through sand or anthracite beds has been used on certain materials; this method is relatively inexpensive although filter runs are short and volume reduction is low (Metcalf and Eddy 1972). Standard pressure or rotating drum filters have been used on radwastes. A precoating of diatomaceous earth or similar material may be required, and centrifugal filters may be used to increase the filtration rate.

Sometimes the sludge can be completely frozen to optimize volume reduction and filterability. It appears that freezing concentrates the ions around colloidal particles giving rise to coagulation. After thawing, the product filters rapidly and a dry cake resuits (IAEA 1964).

\section{Evaporation}

For waste volume reduction and concentration, evaporation is the most effective and universal method but also one of the most expensive. Except for very small amounts of radionuclides entrained in steam, volatile organic compounds, and the few directly volatile radionuclides such as tritium, contamination is almost quantitatively separated. To prevent steam from carrying active ions along in large droplets, it is frequently passed through baffle plates, packed columns, venturi scrubbers, reflux systems, or filters to achieve DFs in the range of $10^{4}$ to $10^{6}$ (IAEA 1964).

An important obstacle to successful decontamination by evaporation is the presence in solution of foam and scale-forming substances. Studies on combating these problems have focused on changing the composition of the solution by prior removal of the surfactants and scale-producing agents and changing the evaporation conditions. Some success has been reported in the use of antifoaming agents (Krause 1977; Mende 1974; Malasek 1967).

Ion exchange on synthetic resins is widely used for the decontamination of wastes with salt concentration of less than $1 \mathrm{~g} / 1$ (Kolychev and Sedov 1968). This process is attractive because of its ease of operation and adaptability to remote and automatic control. If only cation exchange is required, the acidic 
or $\mathrm{H}^{+}$form of resin is usual1y used. If it is known what specific cation is present, other more selective resins may be used. Anion exchange can be used to advantage when a particular isotope (for example, iodine, sulfur, and phosphorus) is present in an anionic form. Normally, anion exchange is used after cation exchange. This two-step process is an effective and frequently used technique.

Organic exchangers are normally insoluble organic polymers with specific groups deliberately introduced to supply the exchangeable ion. The most common of these are the sulphonic, phenolic, and carboxylic groups in the case of cation exchangers and quaternary ammonium, tertiary, secondary, and primary amines in the case of anion exchangers (IAEA 1964).

The advantages of these resins include high exchange capacity, good stability, easy regeneration, and rapid exchange. It should be noted that regeneration capability is not as important as effectiveness and total capacity because many reactor operators are going to one cycle use only for simplicity (Perrigo and Oivine 1979).

Zeolitic ion exchange materials have been shown to be effective for cesium and strontium removal. In particular, Zeolon-900 is reported to be effective on cesium while Amberlite-200 best adsorbs strontium (Wilding and Rhodes 1974). Because Zeolon-900 is highly selective for cesium, a relatively small quantity of ion-exchange material can be used to treat a very large quantity of cesiumcontaminated water.

\section{Foam Separation}

The removal of radioactive species from aqueous solutions by foam separation takes advantage of the concentration difference between surface layers and the bulk regions of solutions containing surfactants. Surfactants reported include lauryl sulphonate, fatty acid salts, and industrial foaming agents such as Sapogen T-Gel and Sulfapol. These materials concentrate at the surface of a solution and can be removed by creating stable aqueous foams. Removal of nonsurface active agents such as metal ions requires that they be complexed into the foam (Malasek 1967). 
A method of purifying low-level aqueous wastes that is based on the principle of complete desalting of the solutions has been developed in the Soviet Union. This process replaces high molecular weight organic ion-exchange resins with partially sulfurated bitumen and various inorganic sorbents. Although this technique will give solutions that are activity free to acceptable standards, it has a number of shortcomings--one of which is the need to reprocess a large volume of regeneration solutions if the content of the salts in the initial solutions is greater than 0.5 to $1 \mathrm{~g} / 1$ (Rauzen and Trushkov 1972).

Volume requirements can be reduced from zeolite- and bitumen-based systems by the use of such proprietary reagents as dualite ARC-359, Dowex 50w-X8, Chelex 100, or Hzo-1. In particular, these have been studied for the removal of cesium, strontium, and plutonium.

\section{Gas Scrubbing}

It is occasionally necessary to remove radioiodine from gas streams before their uncontrolled release. Several methods of acconplishing this have been reported in addition to the general method of using activated charcoal. Deuber and Birke (1978) have reported the use of the sorbtion material OSM 11 . The removal efficiency for iodine-131 in the form of $\mathrm{I}_{2}$ was greater than $99.9 \%$, and residence time was $0.1 \mathrm{sec}$. Removal of iodine-131 in the form of HIO was less than $1 \%$ with the same residence time at $40^{\circ} \mathrm{C}$ and $50 \%$ relative humidity. of the sorbtion materials tested, IPH (supplied by Nuclear Energy Services, Inc.) proved to be the most suitable for removing HIO under the same conditions. Both molecular iodine and methyl iodide have been removed from air streams by electrolytic scrubbing using a solution of cobalt in dilute nitric acid. At a current of $4 \mathrm{~A}$, iodine DFs are about 100 (Mailen and Horner 1976).

\section{Miscellaneous Processes}

Radioactively contaminated water has been reported decontaminated by slurrying with grundite clay. It has been shown that this clay slurry is particularly effective for removing the radioisotopes cerium-141, -144 , praseodymium-144, zirconium-95, niobium-95, barium-140, 1 anthanum-140, strontium-90, and yttrium-90. It was less effective for ruthenium-106 and rhodium-106 and very poor for iodine-131. 
It appears that 1000-ppm clay in water is adequate for batch treatment with greater concentrations being wasteful of clay (Lacy 1954).

Clays and soils can also be used for fixation of radioactive effluent by absorption and fixation of the activity on siliceous materials. These materials, when fired to a high temperature, fix the activity in such a form that it is not leached appreciably by natural waters. The solid wastes produced are then buried (Amphlett 1956). This process is analogous to the vitrification processes currently under study for HLW. 


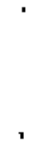




\section{PROCESS REVIEW}

Numerous sources have been examined for possible use in decontamination. Most of the processes have been developed to meet specific decontamination needs and, therefore, are not satisfactory for other cases. As an example of this, consider that over 100 chemical, 25 mechanical, and 5 electrochemical decontamination processes have been tabulated. Further, this tabulation is by no means complete. Ayres (1970), Chopp in et al. (1979), and Remark (1981) provide other compilations with Ayres being the most comprehensive. In addition, there are a few processes that are currently being investigated but are not yet described in the literature for proprietary reasons.

It is believed that, of the published processes, the major variations and some minor ones are included in this report. In reviewing the tabulated processes and considering the needs of decontamination, it is clear that the decontamination process should be based on the following criteria:

- effectiveness - Decontamination must be adequate to meet the objectives of the operation.

- efficiency - The process should not be unduly labor intensive, exposure intensive, or costly in terms of equipment, reagents, or waste disposal.

- safety - The process must not expose personnel to undue hazards or compromise the structural integrity of buildings or systems. The degree of structural integrity required will, or course, depend on whether the decontamination is being performed for reuse or decomissioning.

- waste production - All decontamination methods create radioactive wastes. It is both desirable and usually necessary for compliance with regulations to produce concentrated, solid waste that is not subject to leaching after burial.

The next few sections sumarize the findings of this report. Three groups are described--chemical, mechanical, and electrochemical decontamination 
processes. Each process is further broken down and representative examples are given. Operating information is also discussed.

\section{CHEMICAL OECONTAMINATION PROCESSES}

Chemical decontamination techniques are first divided into high-and lowconcentration processes. In this section the chemical behavior is emphasized over physical differences. Chemical processes can be further divided into six groups:

- high $\mathrm{pH}$ oxidation and dissolution

- high pH oxidation followed by low pH dissolution

- low pH oxidation and dissolution

- low pH oxidation followed by low pH dissolution

- low pH dissolution

- low pH reduction and dissolution.

An example of the high pH oxidation and dissolution is AP, which will dissolve chromium oxide and attacks various hard surfacing alloys, organics, and, to some extent, copper. AP followed by citrox or any other acid step is an example of high $\mathrm{pH}$ oxidation followed by a low $\mathrm{pH}$ dissolution. In this case there is still some dissolution in the first step, but the major purpose of the $A P$ is conditioning the corrosion product; most of the decontamination occurs with the dilute acid step. These processes are generally applied to PWR systems that operate under reducing conditions.

A similar use is made of low $\mathrm{pH}$ oxidation and dissolution. For example, nitric acid can be used as both oxidant and acid, particularly in the case of uranium oxide fuel debris removal; not being a sufficiently strong oxidant, it cannot oxidize $\mathrm{Cr}^{3+}$. Because the composition is proprietary, the placement of NS-1 in this ranking is uncertain; however, NS-1 is a low pH solvent that is thought to be mildly oxidjzing because it can be used to remove copper from 8 WR systems. On the other hand, it is not strongly oxidizing because it is unsuitable for PWR use.

A procedure that is similar to the high $\mathrm{pH}$ oxidation and $\mathrm{low} \mathrm{pH}$ dissolution process uses nitric acid as a low $\mathrm{pH}$ oxidant followed by a low $\mathrm{pH}$ 
dissolution step such as citrox. This process is suitable for the removal of fuel and fission product debris and can be used for corrosion product removal if little or no chromium is present.

There are several examples of solutions for low pH dissolution. The best known of these are phosphoric acid and CAN-DECON; others have been noted in Appendix A. Inhibited phosphoric acid has been used successfully for many years in the $\mathrm{N}$-Reactor--a carbon steel system. CAN-DECON, the only dilute process tested on a reactor-scale operation, has also seen success in carbon steel systems; variations are being examined for use in PWRs.

Low pH strongly reducing systems are not common because reactions with water tend to make them unstable; for example, the $\mathrm{Cr}^{++}$ion. One developed for high-temperature stainless steel is RDS (reducing decontamination solution), which uses hydrazine. For systems that can accept chloride, a solution of hydroxylamine hydrochloride has proven useful for dissolving magnetite.

All of the above solutions, and the only solutions tested in-reactor, have been aqueous. Molten salts and anhydrous acids, such as $\mathrm{H}_{2} \mathrm{SO}_{4}, \mathrm{H}_{3} \mathrm{PO}_{4}$, and $\mathrm{HNO}_{3}-\mathrm{H}_{2} \mathrm{SO}_{4}$, have also been used in the laboratory for descaling and dissolution. These and other nonaqueous systems can have a wider range of basicity, acidity, and reducing and oxidizing potential than aqueous solutions because the less stable water is not present to limit the parameters. Some of these processes are listed in Table A.I in Appendix A.

\section{MECHANICAL DECONTAMINATION PROCESSES}

Mechanical methods of decontamination will usually involve a greater degree of surface removal than either chemical or electrochemical methods. These methods can be broadly designated as either techniques for the removal of surfaces or techniques for the bulk sectioning of equipment and structures.

Abrasive blasting is perhaps the best-known technique for the removal of a variety of contaminated surface materials. An abrasive material is propelled against the contaminated surface a high velocity to remove activity and some of the substrata. The procedures are well established and several variations are 
described in the literature. Other surface removal procedures include spalling (concrete surfaces), hydrolazing for the removal of loose scale and crud from a variety of surfaces, and ultrasonic cleaning for the decontamination of small components with relatively complex geometries.

Explosives are used primarily as a means of sectioning large pieces of equipment so that they can be decontaminated by some other means, if desired. Explosives may also be used to remove concrete surface layers that have been significantly penetrated by contamination. Other sectioning techniques include the arc saw for metal cutting, the plasma arc torch, and flame cutting.

Although mechanical methods are generally not as versatile as chemical methods, they do provide a comparatively straightforward means of decontamination for those surfaces that can tolerate harsher treatment.

\section{ELECTROCHEMICAL DECONTAMINATION PROCESSES}

Electrochemical processes have a major advantage over chemical processes since they can be terminated on demand. On the other hand, it is generally necessary to have the secondary electrode in the immediate vicinity of the area being cleaned. Their use is generally confined to components rather than piping systems. The best-known electrochemical process is electropolishing, which is used to remove the outer surface of a metal object. As the surface is removed, the contamination is undercut; the electrolyte characteristics (viscosity and chemistry) act to prevent contamination from redepositing. Because of the high current densities required for polishing, the process is very rapid.

Other electrochemical processes, such as electrodialysis, are used industrially to purify liquids and have been tested as a means of extracting chloride from concrete on bridges. A possibility exists that with the proper "solvent" this method could be used to extract radionuclides from concrete or soils. 
OPERATIONAL DATA

Operational information such as DFs, corrosion data, safety, and waste disposal techniques is not always provided and may not be provided in terms that are readily usable for decontamination procedures. No one process has presented all the data necessary for use, although the AP-citrox method comes close. For AP-citrox, Ayres (1970) provides comprehensive data on all four of the above topics. Little significant DF, corrosion, or safety data have been developed since that time although new regulations may be more limiting on handling the chemicals. Some new, proprietary information is in the offing on the solidification of AP-citrox.

NS-1 is well documented, particularly in the safety, waste disposal, and corrosion aspects, by Dow Chemical. They have also generated DF data; however, these data are not as comprehensive as those for AP-citrox due to the lack of reactor experience.

Phosphoric acid is well documented in all areas by United Nuclear Industries. Due to its 1 imited use on carbon steel, the total data base is not large.

The CAN-DECON process has the necessary data available but not necessarily in AECL or Ontario Hydro documents. No information has been seen, for example, on the safety of the process. Because of the dilute nature of the chemicals, however, this information is readily available in standard chemistry sources.

Electropolishing is another process that is fairly well documented, but because of its newness for decontamination and current limitations on applicability, its data base, too, is rather small. In this process, of course, the term corrosion rate is somewhat meaningless because the process purposely removes the surface at a controlled rate.

The other processes generally emphasize DF or some relative effectiveness or corrosion behavior with little information on waste disposal or safety. It should be noted that no corrosion data are presented in the table in Appendix A for the chemical processes, except occasionally in the remarks, and that only general surface loss information is presented for the other processes. In the case of the chemical processes, this was done for two reasons. For processes 
such as AP-citrox, so much data are available that it is not feasible to do more than make general comments. For most other processes, little specific data are available--rather the reference has comnents that "corrosion is severe, negligible, ...."

The discussion on waste disposal given by Perrigo et al. (1979) is still valid and should be reviewed. As noted, there are some new processes under development, but they are still proprietary and no new information is available.

\section{CURRENT STATUS OF DECONTAMINATION PROCESSES}

The present status of decontamination processes is one of flux. In the 1950 s and 1960s there was considerable effort expended to develop new processes. During the late 1960s and early 1970s, however, interest decreased and little progress was made in the United States in this area. Recently there has been renewed interest in developing decontamination processes, especially towards dilute chemical or mechanical processes although the more developed of the new techniques are based on concentrated chemicals.

Although the NRC has placed some emphasis on the development of new processes, their major thrust is towards filling some of the gaps in the data of presently existing processes. It is hoped that this document and the following laboratory program will provide operators and regulators alike with sufficient information to make rational selections for any given reactor. 


\section{REFERENCES}

Abrams, C. S., and E. A. Salterelli. 1966. Decontamination of the Shippingport Atomic Power Station. WAPD-299, Bett is Atomic Power Laboratory, Pittsburgh, Pennsylvania.

Allen, R. P., H. W. Arrowsmith, and W. C. Budke. 1978. "Electropolishing as a Large-Scale Decontamination Technique." Paper submitted to 70 th Annual AIChE Meeting, November 13-17, 1977, New York.

Allen, R. P., H. W. Arrowsmith, and M. W. McCoy. 1980. Decontamination of Alpha-Contaminated Materials by Electropolishing and Vibratory Finishing. IAEA-SM-246125. Paper presented at the International Symposium on the Management of Alpha-Contaminated Wastes, International Atomic Energy Agency, June 2-6, 1980, Vienna, Austria.

Amphlett, C. B. 1956. "Fjxation of Radioactive Effluent." Nuclear Eng. June 1956.

Anderson, K. G. 1980. "Experiences in Removing Surfaces with Explosives." In Proceedings of Concrete Decontamination Workshop, ed. A. J. Currie, pp. 99-108 May 28-29, 1980, Seattle, Washington. Pacific Northwest Laboratory, Richland, Washington.

Arrowsmith, H. W., and R. P. Allen. 1978. New Decontamination Techniques for Exposure Reduction. PNL-SA-7279, Pacific Northwest Laboratory, Richland, Washington.

Ayres, J. A. 1966. Decontamination of Pressurized Water Reactors. BNWLSA-640, Pacific Northwest Laboratory, Richland, Washington.

Ayres, J. A. 1967. Decontamination of Water-Cooled Nuclear Reactors-Status and Future Research. BNWL-SA-2 $\overline{4} \overline{6}$, Pacific Northwest Laboratory, Richland, Washington.

Ayres, J. A., ed. 1970. Decontamination of Nuclear Reactors and Equipment. Ronald Press, New York.

Ayres, J. A. 1971. Equipment Decontamination with Special Attention to Solid Waste Treatment-Survey Report. BNWL-B-90, Pacific Northwest Laboratory, Richland, Washington.

Beitel, G. A., and M. P. Schlienger. 1976. ARC Saw Test. ARH-LD-147, Bernaola, 0. A., and A. Filevich. 1970. "Fast Drying Strippable Protective Cover for Radioactive Decontamination." Health Physics 19:685-687.

Carlson, A. B. 1970. "Contamination Mechanisms." In Decontamination of Nuclear Reactors and Equipment, pp. 54-128. Ronald Press, New York. 
Cerré, P. 1970. "Treatment and Disposal of Decontamination Wastes." In Decontamination of Nuclear Reactors and Equipment, ed. J. A. Ayres, pp. 280329. Ronald Press, New York.

Choppin, G. R., et a1. 1979. Literature Review of Dilute Chemical Decontamination Processes for Water-Cooled Nuclear Reactors. EPRI-NP-1033, prepared for Electric Power Research Institute by Pacific Northwest Laboratory, Richland, Washington.

Christensen, E. L. 1959. Procedures for Decontamination of Plutonium from Various Surfaces. LAMS-2319, Los Alamos Scientific Laboratory, Los A7amos, New Mexico.

Combs, A. B., et al. 1980. "A Summary Review of Mound Facility's Experience in Decontamination of Concrete." In Proceedings of Concrete Decontamination Workshop, ed. A. J., Currie, pp. 179-192, May 28-29, Seattle, Washington. Pacific Northwest Laboratory, Richland, Washington.

DeBarr, A. E., and D. A. 0liver. 1968. Electrochemical Machining. American Elsevier, New York.

Deuber, $H_{.}$, and G. Birke. 1977. Determination of the Radioiodine Species in the Exhaust Air of Nuclear Facilities. KFK-2600, Gesellschaft fur Kern

Forschung mbH, Karlsruhe (English Summary pp. 62-63).

Dillon, R. L, et al. 1976. Chemical Decontamination and Melt Densification of Chop-Leach Fuel Hulls. IAEA-SM-207/69, presented at IAEA Meeting on Nuclear Waste Management, March 22-26, 1976, Vienna, Austria.

Dippe 1, T., D. Hentsche1, and S. Kunze. 1976a. "Decontamination and Decontamination Wastes." Kerntechnik. 18:526-531.

Dippe1, T., D. Hentsche1, and S. Kunze. 1976b. "Development of Decontamination Methods. KFK-2375, Semiannual Report 1971/1, Gesellschaft fur Kern

Forschung mbH, Karlsruhe (English Summary pp. 116-118).

Divine, J. R. 1973. "Decontamination of Plutonia-Contaminated Thermal Reactor Systems." Nuclear Technology May 1973.

Dow Chemical Company. 1977. Technical Study for the Chemical Cleaning of Dresden-1. DNS-DI-016, Vol. 1-8, Midland, Michigan.

Erickson, P. B. 1979. "J.S. Licensed Reactor Decomissioning Experience." In Decontamination and Decommissioning of Nuclear Facilities, ed. M. M. Osterhout, pp. 337-348. Plenum Press, New York.

Geckle, R. A. 1980. "Ultrasonic Cleaning." In Metal Finishing--Guidebook Issue, ed. J. Mazia, pp. 144-150. Metals and Plastics Pubtications, Inc., Hackensack, New Jersey. 
Grant, P. J., and J. R. Scherpers, 1978. "Power Plant Water Purification, Chemical Recovery, and Waste Treatment: A Novel Technique with Multiple InPlant Applications." In Proceedings of the American Power Conference, 1978 on Power Plant Water Purification, Chemical Recovery, and Waste Treatment, Vol. 40, Pp.976-985.

Halaris, J. A., and S. A. Bortz. 1980. "High-Pressure Water Jet Applications in Radioactively Contaminated Facilities." In Proceedings of Concrete Decontamination Workshop, ed. A. J. Currie, pp. 193-202, May 28-29, 1980, Seatt1e, Wasington. Pacific Northwest Laboratory, Richland, Washington.

Halter, J. M., and R. G. Sullivan. 1980a. "Equipment for Removal of Contaminated Concrete Surfaces." In Proceedings of Concrete Decontamination Workshop, ed. A. J. Currie, pp, 26-41, May 28-29, 1980, Seattle, washington. Pacific Northwest Laboratory, Richland, Washington.

Halter, 3. M., and R. G. Sullivan. 1980b. Techniques for Removing Contaminated Concrete Surfaces. PNL-SA-8171, Pacific Northwest Laboratory, Richland, Washington.

Hampton, L. U. 1979. Fouling and Chemical Cleaning Studies - CRBRP Evaporators - Part II. GEFR-00449, General Electric Company, Sunnyale, California.

Hayashi, S., S. Araya, and I. Tanaka. 1980. "Experience on the Replacement of the Failed Acid Recovery Evaporator at the Tokai Reprocessing Facility." Presented at the Specialist Meeting on Decommissioning Requirements in the Design of Nuclear Facilities, March 17-19, 1980, Paris, France.

Hignett, J. B. 1980. "Mass Finishing." In Metal Finishing--Guidebook Issue, ed. J. Mazia, pp. 81-106. Metals and Plastics Publications, Inc., Hackensack, New Jersey.

Hi11, A. J. 1970. "Specialized Equipment." In Decontamination of Nuclear Reactors and Equipment, ed. J. A. Ayres, pp. 376-399. Ronald Press, New York.

Horan, J. R., and L. J. Cunningham. 1971. "Decontamination After Widespread Release to the Environment." In Decontamination of Nuclear Reactors and Equipment, ed. J. A. Ayres, pp. 714-754. Ronald Press, New York.

Horsley, G. W. 1961. The Corrosion of Mild Steel, Stainless Steel (18 Cr-8 $\mathrm{Ni}-1 \mathrm{Ti} \mathrm{L}_{2}$ and Incone] by Iodine, Tellurium, Selenium, and Ant imony Vapours. NP-10434, Project DRAGON, Atomic Energy Establishment, winfrith, England.

Imperial Professional Coatings Corp. 1976. Radwaste Solidification and Volune Reduction Process ALARA-Monolith 4000 Series. New Or Teans, Louisiana.

International Atomic Energy Agency (IAEA). 1964. Technology of Radioactive Waste Management Avoiding Environmental Disposal. Vienna, Austria. 
Jumer, J. F. 1980. "Electropolishing." In Metal Finishing--Guidebook Issue, ed. J. Mazia, Pp. 498-499. Metals and Plastics Publications, Inc., Hackensack, New Jersey.

Kolychev, B. S., and V. M. Sedov. 1968. The Present State and Prospects of Development in Radioactive Waste Management in the USSR. State Committee for Utilization of Atomic Energy, Moscow, USSR.

Krause, H. 1977. "Experiences in the Treatment of Radioactive Wastes." Kerntechnik 19(4):171-179.

Lacy, W. J. 1954. "Decontamination of Radioactively Contaminated Water by Slurrying with Clay." Industrial and Engineering Chemistry 46(5):1061-1065.

Lerch, R. E. 1975. Acid Digestion of Combustible Wastes: A Status Report. HEDL-TME 75-5, Hanf ord Engineering Developrient Laboratory, Richland, Washington.

Lindsay, J. W., D. E. Michels, and J. A. Martinez. 1973. Scavenging Contaminated Soil with Polyurethane Foam. RFP-1949, Rocky Flats PTant, Golden, Colorado.

Loucks, C. M. 1971. "Cleaning and Defilming Arts in Industry." In Decontamination of Nuclear Reactors and Equipment, ed. J. A. Ayres, pp. 6-33. Ronald Press, New York.

Mailen, J. C., and D. E. Horner. 1976. "Removal of Radioiodine from Gas Streams by Electrolytic Scrubbing." Nuclear Technology September 1976, pp. 317-324.

Malasek, E. 1967. "Treatment of Radioactive Wastes in Bulgaria, Czechoslovakia, the German Democratic Republic, Hungary, Poland and Romania, "At. Energy Rev. 5(4):151-167.

Manion, W. J. 1979. "A Review of Recent D\&D Program Activities in the International Community." In Decontamination and Decomisnissioning of Nuclear

Facilities, ed. M. M. 0sterhout, pp. 3-8. Plenum Press, New York.

Manion, W. J. 1980. Decontamination Methods as Related to Decommissioning

Nuclear Facilities. Nuclear Energy Services, Inc., Danburg, Connecticut.

Mazia, J. 1980. "Molten Salt Descaling Baths." In Metal Finishing-Guidebook Issue. Metals and Plastics Publications, Inc., Hackensack, New

Jersey.

Merde, H. 1974. "Development and Current Technical Status Decontamination Evaporators." Kerntechnik. 4:170-i77.

Meservey, A. B. 1970. "Decontamination and Film Removal." In Decontamination of Nuclear Reactors and Equipment, ed. J. A. Ayres, pp. 137-159. Ronald Press, New York. 
Metcalf and Eddy. 1972. Wastewater Engineering. McGraw-Hi11, New York.

Moore, P. R. 1974. "Decontamination of a Highly Radioactive Chemical Processing Facility." In Proceedings of the 2nd AEC Environmental Protection Conference, Vol. 2, pp. 7 $\overline{15-720 . ~ W A S H-1332(74), ~ D O E ~ A l b u q u e r q u e ~ O p e r a t i o n s ~ O f f ~ i c e ~}$ and Sandia Laboratories, Albuquerque, New Mexico.

Nelson, R. G., and D. R. Montgomery. 1980. The Cladding Hull Decontamination and Dens if ication Process--Part 2: Densif ication by Inductos lag Melting.

PNL-3166 Pt. 2, Pacific Northwest Laboratory, Richland, Washington.

01sen, R. L., et al. 1980. "Soil Decontamination at Rocky Flats." In Decontamination and Decommissioning of Nuclear Facilities, ed. M. M. Osterhout, Pp. 161-172. PTenum Press, New York.

Perrigo, L. D., et al. 1979. The Impact of Decontamination on LWR Radioactive Waste Treatment Systems. PNL-3297, NUREG/CR-0986, Pacific Northwest Laboratory, Richland, Washington.*

Perrigo, L. D., and J. R. Divine. 1979. Decontamination Methods. PNL-SA-7770, Pacific Northwest Laboratory, Richland, Washington.

Platt, A. M., compiler. 1975. Nuclear Waste Management and Transportation Quarter ly Progress Report January Through March 1975. BNWL-1913, Pacific Northwest Laboratory, Richland, Washington.

Platt, A. M., and J. A. Powell, compilers, 1980. Nuclear Waste Management Quarter Ty Progress Report: 0ctober-December 1979. PNL-3000-4, Pacific Northwest Laboratory, Richland, Washington.

Posselt, H. S., and F. J. Anderson. 1967. "Advances in Caustic Permanganate Descaling." Wire and Wire Products, December 1967, pp. 2184-2188.

Rauzen, F. V., and N. P. Trushkov. 1972. "Testing New Sorbents for the Purification of Liquid Wastes with a Low Level of Radioactivity," trans. Consultant Bureau, UDC 621.039.7; 66.074.7. Atomnaya Energiya 35(2):105-108.

Remark, J. F., ed. 1978. Review of Decontamination Techniques for a Steam Generator. 78:6332-01, Babcock \& Wiicox, Lynchburg, Virginia.

Remark, J. F. 1981. Plant Decontamination Methods Review. NP-1168, prepared for Electric Power Research Institute by Babcock \& Wilcox, Lynchburg, Virginia.

Remark, J. F., and A. D. Miller. 1979. "Review of Plant Decontamination Methods." RDTPL-79-35, paper presented to the American Nuclear Society, September 17-19, 1979, Sun Valley, I daho.

Rohner, M. M. 1978. "Summary of Chemical Decontamination and Seal Ring Repairs at Peach Bottom Station." ANS Transactions, 1978 Winter Meeting, November 12-16, 1978, Washington, D.C. 
Smith, R. I., G. J. Konzek, and W. E. Kennedy, Jr. 1978. Technology, Safety and Costs of Decommissioning a Reference Pressurized Water Reactor Power Station, Vols. 1 and?. NUREG/CR-0130, Pac if ic Northwest Laboratory, Richland, Washington. ${ }^{*}$

Spencer, L. F. 1980. "Abrasive Blasting." In Metal Finishing--Guidebook Issue, ed. J. Mazia, pp. 71-80. Metals and Plastics Publications, Inc., Hackensack, New Jersey.

Straub, C. P. 1972. "Radioactive Wastes - Book Review." Rev. or Radioactive Wastes in Journal WPCF 4(6):1115-1116.

Uh1, D. L., and R. A. Shaw. 1976. Proceedings of the System Contamination Workshop. Electric Power Research Institute, Palo Alto, California.

Uhlig, H. H. 1948. Corrosion Handbook. John Wiley \& Sons, New York.

United Power Association (UPA). 1974. Final Elk River Reactor Program Report. C00-651-93, Elk River, Minnesota.

Ureda, B. F. 1976. Stir Facility Decontamination and Disposition--Final

Report. AI-ERDA-13l68, Rockwell International, Canoga Park, California.

Weed, R. D. 1962. Decontamination of Pressurized-Water Systems. HW-SA-2548, Masters Thesis, University of Washington, Seattie, Washington.

Weed, R. D. 1968. Decontamination of the Plutonium Recycle Test Reactor (PRTR) Primary System. BNWL-711, Pacific Northwest Laboratory, Richland, Washington.

Weed, R. D. 1971. "Decontamination--Historical Survey." In Decontamination of Nuclear Reactors and Equipment, ed. J. A. Ayres, pp. 34-53. Ronald Press, New York.

Wehmann, G., et a1. 1975. Proceedings of the Conference on Decontamination and Decommissioning (D\&D) of ERDA Facilities. CONF-750827, U.S. Energy

Research and Development Administration and Aerojet Nuclear Company, Idaho Falls, Idaho.

White, M. G., and P. B. Dunaway. 1975. The Radioecology of Plutonium and Other Transuranics in Desert Environments. NV0-153, Energy Research and Development Administration, Nevada Operations Office, Las Vegas, Nevada.

Wilding, M. W., and D. W. Rhodes, 1974. Removal of Cesium and Strontium from Fuel Storage Basin Water. ICP-1048, Allied Chemical Corporation, Idaho Chemica] Programs-Operations, Idaho Falls, Idaho.

Wiley, J. R. 1976. A Study of Methods for Removing Strontium, Plutonium, and Ruthenium from Savannah River PTant Waste Supernate. DP-1408, E. I. du Pont de Nemours and Co., Savannah River Laboratory, Aiken, South Carolina. 
Worden, W. P. 1980. "Decontamination--The Utility Viewpoint." In Decontamination and Decommissioning of Nuclear Facilities, ed. M. M. Dsterhout, pp, 1-2. Plenum Press, New York.

Wurm, J. G., "Process for Electro-Chemically Cutting an Irradiated Nuclear Fuel Assembly." Belgian Patent 3,884,784, assignors to Centre d'Etude d'Energie Nucléaire, C.E.N.: E.N.I-Electrische Nijverheids-Installaties, and Belgonuclearje, Brussels, Belgium, July 3, 1972.

ॠÁvailable for purchase from the NRC/GPO Sales Program, U.S. Nuclear Regulatory Comission, Washington, DC 20555, and/or the National Technical Information Service, Springfield, VA 22161.

**Available for purchase from the National Technical Information Service. 


\section{BIBLIOGRAPHY}

Abrams, C. S., and E. A. Salterelli. 1966. Decontamination of the Shippingport Atomic Power Station. WAPD-299, Bett is Atomic Power Laboratory, Pittsourgh, Pennsylvania.

Allen, R. P., et al. 1978. Electropolishing as a Decontamination Process: Progress and Applications. P $\overline{N L}-S A-6858$, Pacific Northwest Laboratory, Richland, Washington.

Allen, R. P., and H. W. Arrowsmith. 1979. Radioactive Decontamination of Metal Surfaces by Electropol ishing. PNL-SA-7267, Pacific Northwest Laboratory, Richland, Washington.

Allen, R. P., H. W. Arrowsmith, and W. C. Budke. 1978. "Electropolishing as a Large-Scale Decontamination Technique." Paper submitted to 70 th Annual AIChE Meeting, November 13-17, 1977, New York.

Allen, R. P., H. W. Arrowsmith, and M. W. McCoy. 1980. Decontamination of Alpha-Contaminated Materials by Electropolishing and Vibratory Finishing. IAEA-SM-246125. Paper presented at the International Symposium on the Management of Alpha-Contaminated Wastes, International Atomic Energy Agency, June 2-6, 1980, Vienna, Austria.

Amphlett, C. B. 1956. "Fixation of Radioactive Effluent." Nuclear Eng. June 1956.

Anderson, K. G. 1980. "Experiences in Removing Surfaces with Explosives." In Proceedings of Concrete Decontamination Workshop, ed. A. J. Currie, pp. 99-198, May 28-29, 1980, Seattle, Washington. Pac if ic Northwest Laboratory, Richland, Washington.

Anschentz, H., "Chemical Cleaning of Objects from Adhering Cement, Concrete or Mortar," German Patent 1,241,925, December 16, 1960.

Anspaugh, L. R. 1974. Evaluation of the Resuspension Pathway Toward Protective Guidelines for Soil Contamination with Radioactivity. UCRL-75250, California University, Livermore, California.

Arbuzova, K. S., et al., "Paste for Cleaning Metallic Working Surfaces of Forming Equipment," Russian Patent 264,962, March 13, 1967.

Arrowsmith, H. W., and R. P. Allen. 1978. New Decontamination Techniques for Exposure Reduction. PNL-SA-7279, Pacific Northwest Laboratory, Richland, Washington.

Arrowsmith, H. W., L. K. Fetrow, and R. P. Allen. 1980. Electrochemical Decontamination of a Radioactive Liquid Waste Tank. Prepared for Puget Sound Shipyard by Pacific Northwest Laboratory, Richland, Washington. 
Ayres, J. A., et al. 1962. Decontamination Studies for HAPO Water-Cooled Reactor Systems: Progress Report--September 1, 1960, Through September 1, 1961. HW-71259, Hanford Atomic Products Operation, Richland, Washington.

Ayres, J. A. 1966. Decontamination of Pressurized Water Reactors. BNWLSA-640, Pacific Northwest Laboratory, Richland, Washington.

Ayres, J. A. 1966. Decontamination of Pressurized Water Reactors. BNWLSA-751, Pacific Northwest Laboratory, Richland, Washington.

Ayres, J. A. 1967. Decontamination of Water-Cooled Nuclear Reactors-Status and Future Research. $\overline{B N W L}-\overline{S A}-2460$, Pacific Northwest Laboratory, Richland, Washington.

Ayres, J. A., ed. 1970. Decontamination of Nuclear Reactors and Equipment. Ronald Press, New York.

Ayres, J. A. 1971. Equipment Decontamination with Special Attention to Solid Waste Treatment-Survey Report. BNWL-B-90, Pacific Northwest Laboratory, Richland, Washington.

Ayres, J. A., and L. D. Perrigo. 1966. Progress Report--Studies on Procedures for Reactor Decontamination--September 1965-May 1966. BNWL-SA-666, Pacific Northwest Laboratory, Richland, Washington.

Ayres, J. A., L. 0. Perrigo, and R. D. Weed. 1966. Contamination and Decontamination of a Pressurjzed Water Reactor. BNWL-SA-938, Pacific Northwest Laboratory, Richland, Washington.

Bagretsov, V. F., G. I. Talkachev, and L. I. Semenova. 1972. "The Use of Nickel Ferrocyanide for the Purification of Deactivation Solutions," trans. Radiokhimya 14(6):854-858.

Bahr, W., W. Hempelmann, and H. Krause. 1976. Incineration Plant for Radioactive Waste at the Nuclear Research Center Karlsruhe. Presented at the 1976 Joint Power Generation Conference, Buffalo, New York.

Beckers, R. M., R. Blumberg, and C. H. Wodtke. 1973. Remotely 0perated Plasma Arc Torch. CONF-731105-1, 0ak Ridge National Laboratory, Oak Ridge, Tennessee.

Beitel, G. A., and M. P. Schlienger. 1976. ARC Saw Test. ARH-LD-147, Atlantic Richfield Hanford Co., Richland, Washington.

Bell, W. E. 1960. "Chemical Cleaning With Citric Acid Solutions." Am. Soc. Mech. Engrs. 60-WA-257, 3 pp.(1960)CA, 56, 5771e.

Be11, W. E., "Scale Removal from Metals," British Patent 1,109,743, April 10, 1968 . 
Berkovich, V. A., et al., "Solution for the Chemical Cleaning of Metal Surfaces," Russian Patent 244,174, February 28, 1967.

Bernaola, 0. A., and A. Filevich. 1970. "Fast Drying Strippable Protective Cover for Radioactive Decontamination." Health Physics 19:685-687.

Boeniger, D., "Liquid Cleaner for Stone or Concrete Surfaces," U.S. Patent $1,575,826$, May $19,1967$.

Brinkman, L. B. 1979. K Through-Reactor Decontamination Engineering Report. DUN-6664, Douglas United Nuclear, Inc., Richland, Washington.

Bruchhausen, V. 1974. Experiences With Inspection, Maintenance, Repair Work and Decontamination in Nuclear Power Plants with Light Water Reactors. EUR5055d, Lahmeyer International B.M.b.H., Frankfurt am Main, F. R. Germany.

Carlson, A. B. 1970. "Contamination Mechanisms." In Decontamination of Nuclear Reactors and Equipment, pp. 54-128. Ronald Press, New York.

Carter, T. J., Jr., et al. 1968. Pigua Nuclear Power Facility Retirement Safet y Analysis Report. AI-AEC-Memo-12708, Atomics Internationa?, Canoga Park, California.

Cerré, P. 1970. "Treatment and Disposal of Decontamination Wastes." In Decontamination of Nuclear Reactors and Equipment, ed. J. A. Ayres, pp. 280-329. Ronald Press, New York.

Chandra, U. 1970. Development of Granular Ion Exchangers from Naturally Occurring Indian Clays: Their Utilization for Decontamination. $\bar{B} \overline{A R C}-457$, Bhabba Atomic Research Centre, Bombay, India.

Choppin, G. R, et al. 1979. Literature Review of Dilute Chemical Decontamination Processes for Water-Cooled Nuclear Reactors. EPRI-NP-1033, prepared for Electric Power Research Institute by Pacific Northwest Laboratory, Richland, Washington.

Christensen, E. L. 1959. Procedures for Decontamination of Plutonium from Various Surfaces. LAMS-2319, Los ATamos Scientific Laboratory, Los A1amos, New Mexico.

Clarke, J. H., et a]. 1969. An Improved Phosphate-Ferrocyanide/Vermiculite Treatment for Harwe 11 Medium Leve] Eff Tuent. AERE-R-6153, Atomic Energy Research Establishment, Harwell, England.

Cloes, K., K. Husmann, and P. von der Hart, 1976. Decontamination of the HFR Dismantling Cell. EUR-5468, Commission of the European Communities, Joint Nuclear Research Centre, Petten, Netherlands.

Cole, C. M., and R. R. Smith. 1978. NWCF/ICPP Remote Decontamination Facility. CONF-781105-47, Allied Chemical Corp., Idaho Falls, Idaho. 
Combs, A. B., et al. 1980. "A Summary Review of Mound Facility's Experience in Decontamination of Concrete." In Proceedings of Concrete Decontamination Workshop, ed. A. J., Currie, pp. 179-192, May 28-29, Seattle, Washington. Pacific Northwest Laboratory, Richland, Washington.

Dana, A. W. 1962. "A Safer Cleaner for Austenitic Stainless Stee1." Metal Progr. 81(4):85-87.

DeBarr, A. E., and D. A. 0liver. 1968. Electrochemical Machining. American Elsevier, New York.

deLora Soria, F., and W. C. Yee. 1967. Decontamination of Radioactive Wastes by Means of Ion Exchange. ORNL-tr-1771, paper presented at the Thirteenth Biennial Meeting of the Spanish Society of Physics and Chemistry, Madrid, Spain.

de Robien, E., J. Pomarola, and M. Brodskey. 1966. Experience Acquired in Regard to Evaporating Liquid Radioactive Waste and Solidifying Evaporation Sludge at the Centres d'etudes Nucleaires de Fontenay-aux-Roses and de Grenoble, trans. S. D. Blalock, Jr. ORNL-tr-4419, Oak Ridge National Laboratory, Oak Ridge, Tennessee.

Deuber, H., and G. Birke. 1977. Determination of the Radjoiodine Species in the Exhaust Air of Nuclear Facilities. KFK-2600, Gesellschaft fur Kern Forchung $\mathrm{mbH}$, KarTsruhe (English Summar y pp. 62-63).

Dillon, R. L., et a1. 1976. Chemical Decontamination and Melt Densification of Chop-Leach Fuel Hulls. IAEA-SM-207/69, Presented at IAEA Meeting on Nuclear Waste Managenent, March 22-26, 1976, Vienna, Austria.

Dillon, R. L., B. Griggs, and J. F. Remark. 1977. Investigation of Alternate Methods of Chemical Decontamination, July-December 1976 (F irst Semiannual Report). BN-SA-703, prepared for the Electric Power Research Institute by Pacific Northwest Laboratory, Richland, Washington.

Dillon, R. L., B. Griggs, and J. F. Remark. 1978. Investigation of Alternate Methods of Chemical Decontamination, January-December 1977 (Second Progress Report) compiler A. B. Johnson, Jr. BN-SA-703-2, prepared for the Electric Power Research Institute by Pacific Northwest Laboratory, Richland, Washington.

Dillon, R. L., and R. S. Kemper. 1978. "Decontamination and Densification of Chop-Leach Cladding Residue." In Quarterly Report, compjlers A. M. Platt and J. A. Powe11. PNL-2377-3, Pacific Northwest Laboratory, Richland, Washington.

Dippe], T., D. Hentsche1, and S. Kunze. 1976a. "Decontamination and Decontami nat i on Wastes." Kerntechnik. 18:526-531. 
Dippel, T., D. Hentsche I, and S. Kunze. 1976b. "Development of Decontamination Methods. KFK-2375, Semiannual Report 1971/1, Gesellschaft fur Kern Forschung $\mathrm{mb} H$, Karlsruhe (English Summary pp. 116-118).

Dippe], T., D. Hentschel, and S. Kunze. 1977. Development of Decontamination Methods. KFK-2500, Gesellschaft fur Kern Forschung mbH, Karlsruhe (English Sumary, pp. 107-109).

Divine, J. R. 1973. "Decontamination of Plutonia-Contaminated Thermal Reactor Systems." Nuclear Technology May 1973.

Dow Chemical Company. 1977. Technical Study for the Chemical Cleaning of Dresden-I. DNS-DI-016, Vol. 1-8, Midland, Michigan.

Efimivov, I. A., et al. 1980. Decontamination of the Primary Loop of BR-5, trans. R. G. Gier. RH0-TR-00006 (KFK-tr-480) Rockwell Hanford Dperations, Richland, Washington.

El-Waki1, M. M. 1962. Nuclear Power Engineering. McGraw-Hill, New York.

Erickson, P. B. 1979. "U.S. Licensed Reactor Decommissioning Experience." In Decontamination and Decomissioning of Nuclear Facilities, ed. M. M. Osterhout, pp. 337-348. Plenum Press, New York.

Faust, R. A., C. S. Forea, and N. P. Knox, compilers, 1979. Decommissioning of Nuclear Facilities--A Selected Bibliography. DRNL/EIS-154/VI Oak Ridge Nationa? Laboratory, Oak Ridge, Tennessee.

Ferguson, D. B., J. W. Frymier, and J. L. Lorenzen. 1973. N-Reactor Piping Decontamination, 1973. DUN-8131, Douglas United Nuclear, Inc., Richland, Washington.

Fominykh, V. E., V. V. Pushkarev, and N. N. Pustovalov. 1973. "Foam Flotation of Clay Sorbents as a Deactivation Method," trans. Plenum Publishing Co., UDC 16.066.661.185. Radiokhimya 16(4):539-543.

Foster, C. B., and M. J. Szulinski. 1974. Decontamination of Obsolete Processing Facilities at Hanford. ARH-SA-183, At lantic Richfield Hanford Co., Richland, Washington.

Geckle, R. A. 198D. "Ultrasonic Cleaning." In Metal Finishing--Guidebook Issue, ed. J. Mazia, pp. 144-150. Metals and Plastics Publications, Inc., Hackensack, New Jersey.

Gemel1, L. 1963. Decontamination Methods, Equipment and Materials. BNL7665 , 8rookhaven National Laboratory, Upton, New York.

Glauberman, H., et al. 1977. Technical and Economic Aspects of Nuclear Power Plant Decomissioning. IAEA-CN-36/16, International Atomic Energy Agency, Vienna, Austria. 
Goerrig, D., W. Shlabach, and F. Schubert, "Metal Surface Cleaning Agents," German Patent 1,074,356, January 28, 1960.

Goldberg, G. 1978. "Testing of Coatings for the Nuclear Industry." Ind. Eng. Chem. Prod. Res. Dev. 17(1):25-27.

Graham, H. B. 1975. Status on Decommissioning of Nuclear Reprocessing Facilities. CONF-750822-6, Oak Ridge National Laboratory, Oak Ridge, Tennessee.

Grant, P. J., and J. R. Scherpers. 1978. "Power Plant Water Purification, Chemical Recovery, and Waste Treatment: A Novel Technique with Multiple InPlant Applications." In Proceedings of the American Power Conference, 1978 on Power Plant Water Purification, Chemical Recovery, and Waste Treatment, Vol. 40, pp. 976-985.

Groenier, W. S. 1973. An Engineering Evaluation of the Iodex Process: Removal of Iodine from Air Using a Nitric Acid Scrub in a Packed CoTumn. ORNLTM-4125, Oak Ridge National Laboratory, Oak Ridge, Tennessee.

Halaris, J. A., and S. A. Bortz. 1980. "High-Pressure Water Jet Applications in Radioactively Contaminated Facilities.". In Proceedings of Concrete Decontamination Workshop, ed. A. J. Currie, pp. 193-202, May 28-29, 1980, Seattle, Washington. Pacific Northwest Laboratory, Richland, Washington.

Ha 11, T. M., and W. K. Kratzer. 1976. Decontamination of 109 Cell Primary Cooling System Piping. UNI-105-A, Boston College, Chestnut HilT, Massachusetts.

Halter, J. M., and R. G. Sullivan. 1980. "Equipment for Removal of Contaminated Concrete Surfaces." In Proceedings of Concrete Decontamination Workshop, ed. A. J. Currie, May 28-29, 1980, Seatt7e, Washington. Pacific Northwest Laboratory, Richland, Washington.

Halter, J. M., and R. G. Sullivan. 1980b. Techniques for Removing Contaminated Concrete Surfaces. PNL-SA-8171, Pacific Northwest Laboratory, Richland, Washington.

Hampton, L. U. 1979. Fouling and Chemical Cleaning Studies - CRBRP Evaporators - Part II. GEFR-00449, General Electric Company, Sunnyvale, California.

Harmon, H. D. 1975. The Decontamination of Dissolved U-Al Fuel By Simultaneous Treatment with Gelatin and $\mathrm{MnO}_{2}$. DP-1376, E. I. du Pont de Nemours and Co., Savannah River Laboratory, Aiken, South Carolina.

Hayashi, S., S. Araya, and I. Tanaka. 1980. "Experience on the Replacement of the Failed Acid Recovery Evaporator at the Tokai Reprocessing Facility." Presented at the Specialist Meeting on Decomnissioning Requirements in the Design of Nuclear Facilities, March 17-19, 1980, Paris, France. 
Heitman, H. G., and W. Ziehl, "Descaling Iron-Containing Materials," U.S. Patent 3,085,915, April 16, 1963.

Herald, W. R., R. C. Roberts, and M. K. Williams. 1978. Development of Ultrafiltration and Inorganic Adsorbents for Reducing Volumes of Low-Level and Intermediate-Level Liquid Waste: July-September 1978. MLM-2566, Monsanto Research Corporation, Mound Facility, Miamisburg, Ohio.

Hershey, J. H. 1975. Separations Canyon Decontamination Facilities. DPSPU75-30-5, E. I. du Pont de Nemours and Co., Aiken, South Carolina.

Hignett, J. B. 1980. "Mass Finishing." In Metal Finishing--Guidebook Issue, ed. J. Mazia, pp. 81-106. Metals and Plastics Publications, Inc., Hackensack, New Jersey.

Hill, A. J. 1970. "Specialized Equipment." In Decontamination of Nuclear Reactors and Equipment, ed. J. A. Ayres, pp. 376- $\overline{399}$. Ronald Press, New York.

Hill, G. S. 1979. Doses for Various Pathways to Man Based on Unit Concentrations of Radionuclides Pertinent to Decontamination and Decommissioning of Properties. ORNL/OEPA-7, Oak Rjdge National Laboratory, Oak Ridge, Tennessee.

Holcomb, H. P., J. H. Horton, and E. L. WiThite. 1976. Actinide-Soil Interactions in Waste Management at the Savannah River Plant. DP-MS-74-118, E. $\bar{I}$. du Pont de Nemours and Co., Aiken, South Carolina.

Holladay, D. W. 1979. Literature Survey: Methods for the Removal of Iodine Species from off-Gases and Liquid Waste Streams of Nuclear Power and Nuclear Fuel Reprocessing Plants. ORNL/TM-6350, 0ak Ridge National Laboratory, 0ak Ridge, Tennessee.

Horan, J. R., and L. J. Cunningham. 1971. "Decontamination After Widespread Release to the Environment." In Decontamination of Nuclear Reactors and Equipment, ed. J. A. Ayres, pp. 714-754. Ronald Press, New York.

Horsley, G. W. 1961. The Corrosion of Mild Stee1, Stainless Steel (18 Cr-8 $\mathrm{Ni}-1 \mathrm{Ti}$, and Inconel by Iodine, Tellurium, Selenium, and Antimony Vapours. NP-10434, Project DRAGON, Atomic Energy Establishment, Winfrith, England.

Horton, J. H., and E. L. Albenesius. 1976. "Volume Reduction of Plutonium Contaminated Soil." Nuclear Technology July 1976, pp. 86-88.

Imperial Professional Coatings Corp. 1976. Radwaste Solidification and Volume Reduction Process ALARA-Monolith 4000 Series. New Orleans, Louisiana.

Innes, W. P. 1980. "Metal Cleaning." In Metal Finishing--Guidebook Issue, ed. J. Mazia, pp. 118-143. Metals and Plastics Publications, Inc., Hackensack, New Jersey.

International Atomic Energy Agency (IAEA). 1964. Technology of Radioactive Waste Management Avoiding Environmental Disposal. Vienna, Austria. 
International Atomic Energy Agency (IAEA). 1965. The Management of Radioactive Wastes Produced by Radioisotope Users. Vienna, Austria.

Johannsen, K. H. 1971. Flocculation and Sedimentation of Suspended Radioactive Contaminants in Waste by Control of the Zeta Potential. AEC-tr-7433, Staatlich Zentrale fuer Strahlenshutz, Berlin, East Germany.

Johannsen, K. H., and W. Lenk. 1969. Sorption of Radionuclides on Friable Soils and 0ther Natural Absorbents. SZS-669, Staatich Zentrale fuer Strahlenshutz, Berlin, East Germany.

Johnson, A. B., Jr., et a1. 1979. "Candidate Reagents for Activity Reduction in BWR and PWR Primary Systems." BN-SA-970, paper presented at ANS Topical Meeting on Decontamination and Decommissioning, September 16-20,1979, Sun Valley, Idaho.

Johnson, A. B., Jr., B. Griggs, and F. M. Kustus. 1980. "Nature of Deposits on BWR and PWR Primary System Surfaces--Relation to Decontamination." Presented at Water Chemistry II, British Nuclear Energy Society, paper 54.

Jumer, J. F. 1980. "Electropolishing." In Metal Finishing--Guidebook Issue, ed. J. Mazia, pp. 498-499. Metals and Plastics Publications, Inc., Hackensack, New Jersey.

Junghans, C. A., and J. C. Clausing. 1969. Special Operating Procedure: Cell 1 Decontamination. DUN-6075, Douglas United Nuclear, Inc., Richland, Washington.

Kalandiya, A. A. 1973. "Efficiency of Deactivation of Drinking Water from Certain Fission Products by K-Askangel," trans. Consultants Bureau, UDC 663.632 ; 541.183.1; 539.173.8. Radiokhimya 16(1):44-50.

Kettler, R. E., "Cleaning Masonry with Chemical Solutions," U.S. Patent 3,505,112, September 5, 1967.

King, L. J., A. Shimozato, and J. M. Holmes, 1968. Pilot Plant Studies of the Decontamination of Low-Level Process Wastes by a Scavenging-Precipitation Foam Separation Process. ORNL-3803, Oak Ridge National Laboratory, Oak Ridge, Tennessee.

Koenst, J. W., and R. C. Roberts. 1978. Evaluation of UItrafiltration Membranes for Treating Low-Level Radioactive Contaminated Liquid Waste. MLM-2448, Monsanto Research Corporation, Mound Facility, Miamisburg, Ohio.

Kolychev, B. S., A. N. Matreev, and A. A. Khonikevich. 1968. "Handling of Radioactive Waste at Soviet Nuclear Power Stations," trans. Atomnaya Energiya 26(5):411-419, UDC 621.039.75.

Kolychev, B. S., and V. M. Sedov, 1968. The Present State and Prospects of Development in Radioactive Waste Management in the ISSSR. State Committee for Utilization of Atomic Energy, Moscow, USSR. 
Konzek, G. J., and C. R. Sample. 1978. Decomissioning of Nuclear Facilities--An Annotated Bibliography. NUREG/CR-0131, Pacific Northwest Laboratory, Richland, Washington.*

Korn, R., G. Seyd, and U. Paulson, "Method of Cleaning Nuclear Power Plants," German Patent $3,894,364$, assignors to Siemens Aktiengesellschaft, Munich, Germany, 1973.

Kratzer, W. K. 1967. "Single Pass Through-Reactor Decontamination of $\mathrm{N}$-Reactor Methods for $\mathrm{N}$ Reactor's Decontamination Wastes." Presented at National Association of Corrosion Engineers, Houston, Texas.

Kratzer, W. K. 1975. Decontamination and Decontaminant Waste Disposal. UNISA-18, United Nuclear Industries, Inc., Richland, Washington.

Kratzer, W. K. 1979. Advanced Decontamination Program - Interim Report No. 1. UNI-1425, United Nuclear Industries, Inc., Richland, Washington.

Kratzer, W. K., and W. D. Bainard. 1969. Development of a Waste Disposa] Method for $N$ Reactor's Decontamination Wastes. OUN-SA-125, Douglas United Nuclear, Inc., Richland, Washington.

Krause, H. 1972. Kernforshungszentrum Karlsruhe. KFK-2000, Department of Decontamination 0perations, Annual Report 1972, Gessel1schaft fur Kern Forschung mbH, Karlsruhe.

Krause, H. 1977. "Experiences in the Treatment of Radioactive Wastes." Kerntechnik 19(4):171-179.

Krause, H., and G. Rudolph. 1975. Decontamination Service: Annual Report, 1973. KFK-2128, Kern Forschungszentrum, Karlsruhe.

Kunze, S. 1976. Decontaminable Floor Materials for Nuclear Power Plants, trans. Foreign Research Associates. RFP-Trans-229, Rockwel] International, Atomics International Division, Rocky Flats Plant, Golden, Colorado.

Kusier, L. E. 1977. Survey of Decontamination and Decormissioning Techniques. ARH-CD-784, Atlantic Richfield Hanford Co., Richland, Washington.

Lacy, W. J. 1954. "Decontamination of Radioactively Contaminated Water by Slurrying with Clay." Industrial and Engineering Chemistry 46(5):1061-1065.

Lagerwerff, J. V., and W. D. Kemper. 1975. "Reclamation of Soils Contaminated with Radioactive Strontium." Soil Science 139:1077-1080.

LaGuardia, T. S. 1980. "Concrete Decontamination and Demolition Methods." In Proceedings of Concrete Decontamination Workshop, ed. A. J. Currie, pp. 1-26, May 28-29, 1980, Seattle, Washington. Pacific Northwest Laboratory, Richland, Washington. 
Lambright, T. M. 1979. "Decontamination and Densification of Chop-Leach Cladding Residues." In Nuclear Waste Management Quarterly Progress Report, 0ctober Through December 1978, compilers A. M. Platt and J. A. Powe11, Section 1.0. PNL-2378-4, Pacific Northwest Laboratory, Richland, Washington.

Larrick, A. P., et a]. 1978. PWR Steam Generator Chemical Cleaning--Phase I Final Report, Vol. I and II. UNI-785087, prepared for Consolidated Edison Company by United Nuc Tear Industries, Inc.

Lee, S. K., "Electrochemical Containment Removal from Aqueous Media," U.S. Patent $3,926,754$, assignor to Andco Incorporated, Buffalo, New York, February 16, 1973.

Lerch, R. E. 1975. Acid Digestion of Combustible Wastes: A Status Report. HEDL-TME 75-5, Hanford Engineering Development Laboratory, Richland, Washington.

Lin, K. H. 1973. Use of Ion Exchange for the Treatment of Liquids in Nuclear Power Plants. ORNL-4792, Oak Ridge National Laboratory, Oak Ridge, Tennessee.

Lindsay, J. W., D. E. Michels, and J. A. Martinez. 1973. Scavenging Contaminated Soil with Polyurethane Foam. RFP-1949, Rocky Flats Plant, Golden, Cotorado.

Loucks, C. M. 1971. "Cleaning and Defilming Arts in Industry." In Decontamination of Nuclear Reactors and Equipment, ed. J. A. Ayres, pp. 6-33. Ronald Press, New York.

Lunis, B. C. 1975. "Program Plan for Removal of the Materials Test Reactor Overhead Working Reservoir." In Proceedings of the Conference on Decontamination and Decommissioning (D\&D) of ERDA Facilities, CONF-750827, U.S. Energy Research and Development Administration and Aerojet Nuclear Company, Idaho Falls, Idaho.

Mailen, J. C., and D. E. Horner. 1976. "Removal of Radioiodine from Gas Streams by Electrolytic Scrubbing." Nuclear Technology September 1976 pp. 317-324.

Malasek, E. 1967. "Treatment of Radioactive Wastes in Bulgaria, Czechoslovakia, the German Democratic Republic, Hungary, Poland and Romania." At. Energy Rev. 5(4):151-167.

Manion, W. J. 1979. "A Review of Recent D\&D Program Activities in the International Community." In Decontamination and Decommissioning of Nuclear Facilities, ed. M. M. Osterhaut, pp. 3-8. PTenum Press, New York.

Manion, W. J. 1980. Decontamination Methods as Related to Decommissioning Nuclear Facilities. Nuclear Energy Services, Inc., Danburg, Connecticut. 
Marsh, G. P., and R. Perkins. 1978. The Corrosion of $9 \mathrm{Cr}-1$ Mo Ferritic Boiler Tube Steel in Strong Caustic Solutions. AERE-R-9267, Atomic Energy Research Establishment, Harwe 1], England.

Mazia, J. 1980. "Molten Salt Descaling Baths." In Metal Finishing-Guidebook Issue. Metals and Plastics Publications, Inc., Hackensack, New Jersey.

McCoy, M. W., R. P. Allen, and H. W. Arrowsmith. 1980. Surface Decontamination of Solid Waste. PNL-SA-8368, Pacific Northwest Laboratory, Richland, Washington.

McCoy, M. W., H. W. Arrowsmith, and R. P. Allen. 1980. Vibratory Finishing as a Decontamination Process. PNL-3336, Pacific Northwest Laboratory, Richland, washington.

Means, J. L., and D. A. Crerar. 1978. "Migration of Radioactive Wastes: Radionuclide Mobilization by Complexing Agents." Science, June 30, 1978, pp. 1477-1481.

Merde, H. 1974. "Development and Current Technical Status of Decontamination Evaporators." Kerntechnik. 4:170-177.

Mercer, B. W., and L. L. Anes. 1977. Evaluation of a Precipitation-Ion Exchange Process for Treatment of Laundry Waste. BNWL-2274, Pacific Northwest Laboratory, Richland, Washington.

Meservey, A. B. 1970. "Decontamination and Film Removal." In Decontamination of Nuclear Reactors and Equipment, ed. J. A. Ayres, pp. 137-159. Ronald Press, New York.

Metcalf and Eddy. 1972. Wastewater Engineering. McGraw-Hil1, New York.

Miner, F. J. 1978. Chemistry Research and Development Progress Report for July 1977 Through April 1978. RFP-2803, Rockwell International, Rocky Flats Plant, Golden, Colorado.

Mituishi, N., T. Fukumoto, and N. Hamada. 1967. "Studies on Removal of Radioactive Mist by Plate Column." J. of Nuclear Science and Technology 4(2):74-83.

Moore, P. R. 1974. "Decontamination of a Highly Radioactive Chemical Processing Facility." In Proceedings of the 2nd AEC Environmental Protection Conference, Vol. 2, pp. 715-720. WASH-1332(74), D0E A1buquerque Operations Office and Sandia Laboratories, Albuquerque, New Mexico.

Morris, E. B. 1961. "Precautions in the Use of Citric Acid for Chemical Cleaning." J. Eng. Power 83:367-370. 
Murphey, E. S., and G. M. Holter. 1980. Technology, Safety and Costs of Decommissioning a Reference Low-Leve] Waste Burial Ground. PNL-2956, Pacific Northwest Laboratory, Richland, Washington.

Nakoyama, T., "Anticorrosion Agents for Iron," Japanese Patent 7,12D,241, June $7,1971$.

Navrati1, J. D. 1978. Chemical Research at Rocky Flats. RFP-2774, Rocky Flats Plants, Atomics International Div., Golden, Colorado.

Navratil, J. D., G. K. Thompson, and R. Kochen. 1978. Waste Management of Actinide Contaminated Soil. RFP-2856, Rocky Flats Plant, Atomics International Div., Golden, Colorado.

Neilson, R. M., and P. Colombo. 1977. Solidification of Liquid Concentrate and Solid Waste Generated as By-Products of the Liquid Radwaste Treatment Systems in Light-water Reactors. BNL-NUREG-22839, Brookhaven Nationa 1 Laboratory, Upton, New York.

Nelson, R. G., and D. R. Montgomery. 1980. The Cladding Hull Decontamination and Densification Process--Part 2: Dens if ication by Inductoslag Melting.

PNL-3166 Pt. 2, Pacific Northwest Laboratory, Richland, Washington.

Oak, H. D., et al. 1980. Technology, Safety and Costs of Decommissioning a Reference Boiling Water Reactor Power Station. PNL-3305 V. 2 App., Pacific Northwest Laboratory, Richland, Washington.

O'Donnel1, F. R., and S. J. Cotter. 1978. Potential Radiation Dose to Man from Recycle of Metals Reclaimed from a Decommissioned Nuclear Power Plant. NUREG/CR-0134, Dak Ridge National Laboratory, Oak Ridge, Tennessee.*

Dertel, K., et al. 1978. Decontamination of Primary Loop Equipment with Ethylenediaminetetraacet ic Acid. BNWL-TR-290, Pacific Northwest Laboratory, Richland, Washington.

01sen, R. L., et al. 1979. Soil Decontamination at Rocky Flats. RFP-2901, Rockwell International Corp., Canoga Park, California.

0isen, R. L., et al. 1980. "Soil Decontamination at Rocky Flats." In Decontamination and Decommissioning of Nuclear Facilities, ed. M. M. Osterhout, pp. 161-172. Plenum Press, New York.

Owen, W. L., et a1. 1967. Radiological Reclamation Performance Summary, Vol. II. Evaluation and Condensation of Data for Replanning, etc. AD-674-863, Naval Radiological Defense Laboratory, San Francisco, California.

Paschall, R. K. 1975. Decontamination and Decommissioning Criteria for Use in Design of New Plutonium Facilities. AI-ERDA-13156, Atomics International Division, Canoga Park, California. 
Pattison, J., and I. J. Davis. 1966. Decontamination of Stainless Steel Loop Pipework Using a Peroxide-Inhibited Solution of Oxalic Acid. DP-Report-410, Atomic Energy Research Establishment, Harwell, England.

Perrigo, L. D., et al. 1979. The Impact of Decontamination on LWR Radioactive Waste Treatment Systems. PNL -3297 , NUREG/CR-0986, Pacific Northwest

Laboratory, Richland, Washington. ${ }^{\star \star}$

Perrigo, L. D., and 3. R. Divine. 1979. Decontamination Methods. PNL-SA-7770, Pacific Northwest Laboratory, Richland, Washington.

Platt, A. M., compiler. 1975a. Nuclear Waste Management and Transportation Quarter ly Progress Report January Through March 1975. BNWL-1913, Pacific Northwest Laboratory, Richland, Washington.

Platt, A. M., compiler. 1975b. Nuclear Waste Management and Quarterly Progress Report Apri1 Through June 1975. BNWL-1936, Pacific Northwest

Laboratory, Richland, Washington.

Platt, A. M., compiler. 1975c. Nuclear Waste Management and Quarterly Progress Report July Through September 1975. BNWL-1952, Pacific Northwest Laboratory, Richland, Washington.

Platt, A. M. 1976. Nuclear Waste Management Quarterly Progress Report October Through December 1976. BNWL-2245, Pacific Northwest Laboratory, Richtand, Washington.

Platt, A. M., compiler. 1977. Nuclear Waste Management Quarterly Progress Report October Through December 1976. BNwL-2245, Pacific Northwest Laboratory, Richland, Washington.

Platt, A. M., and J. A. Powell, compilers. 1980. Nuclear Waste Management Quarter ly Progress Report: October-December 1979. PNL-3000-4, Pacific Northwest Laboratory, Richland, Washington.

Posselt, H. S., and F. J. Anderson. 1967. "Advances in Caustic Permanganate Descaling." Wire and Wire Products, December 1967, pp. 2184-2188.

Poutter, D. R. 1963. The Design of Gas-Cooled Graphite-Moderated Reactors. Oxford University Press, London.

Rauzen, F. V., and N. P. Trushkov. 1972. "Testing New Sorbents for the Purification of Liquid Wastes with a Low Level of Radioactivity," trans. Consultant Bureau, UDC 621.039.7; 66.074.7. Atomnaya Energiya 35(2):105-108.

Reich, C. F., "Procedure for Scale Removal," French Patent 1,399,404, May 14, 1965. 
Remark, J. F. 1976. Investigation of Alternate Methods of Chenical Decontamination--First SemiannuaT Report. BN-SA-703, Pacific Northwest Laboratory, Richland, Washington.

Remark, J. F., ed. 1978. Review of Decontamination Techniques for a Steam Generator. 78:6332-01, Babcock \& Wilcox, Lynchburg, Virginia.

Remark, J. F. 1981. Plant Decontamination Methods Review. NP-1168, prepared for Electric Power Research Institute by Babcock \& Wilcox, Lynchburg, Virginia.

Remark, J. F., and A. D. Miller, 1979. "Review of Plant Decontamination Methods." RDTPL-79-35, paper presented to the American Nuclear Society, September 17-19, 1979, Sun Valley, I daho.

Robev, S. K., et a1. 1965. Method for Deactivating Contaminated Surfaces by Film, trans. J. D. Kaser. AEC-tr-7218, International Atomic Energy Agency, Vienna, Austria.

Rodier, J., and C. Vernhes. 1971. "Antipollution and Radioactive Wastes." Dunod, Paris, France (1970); Nuclear Society Abstracts, 25, 13087, (1971).

Rohner, M. M. 1978. "Summary of Chemical'Decontamination and Seal Ring Repairs at Peach Bottom Station." ANS Transactions, 1978 Winter Meeting, November 12-16, 1978, Washington D.C.

Rostosky, M., "Descaling of Metal Surfaces," German Patent 1,073,826, Januar y 12, 1960.

Ryabchikov, B. E., et al. 1974. "Purification of Liquid Radioactive Effluents by Continuous I on Exchange," trans. Consultants Bureau, UDC 621.039.73. Atomna ya Energiya 38(4):222-225.

Sande, W. E., et al., compilers. 1975. Decontamination and Decomissioning of Nuclear Facilities--A Literature Search. BNWL-1917, Pacific Northwest Laboratory, Richland, washington.

Schmidsranter, A. P., and $H$. Glemser, "Cleaning Metal Surfaces," French Patent $1,491,654$, August 11,1967 .

Science Applications, Inc. (SAI). 1978. Technical Support for GEIS: Radioactive Waste Isolation in Geologic Formations. Y/OWI/TM-36/22, 0ak Ridge, Tennessee.

Smith, 0. L. 1979. Final Report, SPERT-IV Decontamination \& Decomissioning. TREE-1373, EG\&G Idaho, Inc., İdaho Falls, Idaho.

Smith, R. 1., G. J. Konzek, and W. E. Kennedy, Jr. 1978. Technology, Safety and Costs of Decommissioning a Reference Pressurized Water Reactor Power Station, Vols. 1 and 2. NUREG/CR-0130, Pacific Northwest Laboratory, Richiand, Washington.* 
Smith, R. I., and L. M. Polentz. 1979. Technology, Safety and Costs of Decommissioning a Reference Pressurized Water Reactor Power Station. NUREG/CR-0130, Pacific Northwest Laboratory, Richland, Washington. *

Spencer, L. F. 1980. "Abrasive Blasting." In Metal Finishing--Guidebook Issue, ed. J. Mazia, pp. 71-80. Metals and Plastics Publications, Inc., Hackens ack, New Jersey.

Spillner, F. 1967. "The Reaction-Accelerating Effect of Fluorides During the Pickling of Scale Affected Iron Parts." Werkst. Korros. 18(9):784-93.

Squire, A. T., "Noncorrosive Rust Remover," U.S. Patent 3,510,432, May 5, 1970. Starr, C., and R. W. Dickenson. 1958. Sodium Graphite Reactors. AddisonWesley, Reading, Massachusetts.

Steindler, M. J., et al. 1975. Chemical Engineering Division, Waste Management Programs--Quarter ly Report, July-September 1974. ANL-8152, Argonne National Laboratory, Argonne, Illinois.

Stel10, V. 1979. "NRC's View of Decontamination and Decommissioning." In Decontamination and Decomissioning of Nuclear Facilities, ed. M. M. Osterhout, pp. 9-12. Plenum Press, New York.

Stinnett, W. 1964. Decontamination Facility and Warm Equipment and Parts Storage Facility. RN-S-0007, Aerojet-General Corp., Azusa, California.

Stoeckert, H., K. Appler, and P. Schroeder. 1973. Decontamination of Different Aerosol Contaminated Surfaces. BMFT-FBK-73-15, ErTangen, West Germany.

Straub, C. P. 1972. "Radioactive Wastes - Book Review." Rev. of Radioactive Wastes in Journal WPCF $4(6): 1115-1116$.

Sugaiski, A., and E. J. Jagielski. 1967. Experiences with Latex-Type Materials as Decontaminating Agents. KAPL-P-3366, Knol1s Atomic Power Laboratory, Schenectady, New York.

Taylor, R., and W. D. Yuille. 1971. Trapping of Methyl Iodide at High Pressure and High Temperature. TRG-Report-2135, United Kingdom Atomic Energy Authority-Reactor Group, Sellafield, England.

Uh1, D. L., and R. A. Shaw. 1976. Proceedings of the System Contamination Workshop. Electric Power Research Institute, Palo Alto, California.

Uhlig, H. H. 1948. Corrosion Handbook. John Wiley \& Sons, New York.

United Power Association (UPA). 1974. Final Elk River Reactor Program Report. C00-651-93, Elk River, Minnesota. 
Ureda, B. F. 1976. Stir Facility Decontamination and Disposition--Final Report. AI-ERDA-13168, Rockwell International, Canoga Park, California.

Verot, Jean-Louis, et al., "Methods of Decontaminating Radioactive Wastes," French Patent 3,658,714, assignors to Ugine Kuhlmann, Paris, France, December 4, 1980.

Von Neida, G. E. June 1978. "Corrosion Film Characterization." American Nuclear Society Trans. 28:132-133.

Wahlen, R. K. 1974. Low pH Decontamination Procedure Ce11 3. UNI-136, United Nuclear Industries, Inc., Richland, Washington.

Weed, R. D. 1962. Decontamination of Pressurized-Water Systems. HW-SA-2548, Masters Thesis, University of Washington, Seattle, Washington.

Weed, R. D. 1968. Decontamination of the Plutonium Recycle Test Reactor (PRTR) Primary System. BNWL-711, Pacific Northwest Laboratory, Richland, Washington.

Weed, R. D. 1971. "Decontamination--Historical Survey." In Decontamination of Nuclear Reactors and Equipment, ed. J. A. Ayres, pp. 34-53. Ronald Press, New York.

Wehmann, G., et a1. 1975. Proceedings of the Conference on Decontamination and Decommissioning (D\&D) of ERDA Facilities. CONF-750827, U.S. Energy Research and Development Administration and Aerojet Nuclear Company, Idaho Falls, Idaho.

White, M. G., and P. B. Dunaway. 1975. The Radioecology of Plutonium and Other Transuranics in Desert Environments. NV0-153, Energy Research and Development Administration, Nevada Operations Office, Las Vegas, Nevada.

Wilding, M. W., and D. W. Rhodes. 1963. Removal of Radioisotopes from Solution by Earth Materials from Eastern Idaho. ID0-14624, Phillips Petroleum Co., Atomic Energy Division, Idaho Falls, Idaho.

Wilding, M. W., and D. W. Rhodes. 1974. Removal of Cesium and Strontium from Fuel Storage Basin Water. ICP-1048, Allied Chemical Corporation, Idaho Chemical Programs-0perations, Idaho Falls, Idaho.

Wiley, J. R. 1976. A Study of Methods for Removing Strontium, Plutonium, and Ruthenium from Savannah River Plant Waste Supernate. DP-1408, E. I. du Pont de Nemours and Co., Savannah River Laboratory, Aiken, South Carolina.

Worden, W. P. 1980. "Decontamination--The Utility Viewpoint." In Decontamination and Decommissioning of Nuclear Facilities, ed. M. M. Osterhout, pp. 1-2. Plenum Press, New York. 
Wurm, J. G., "Process for Electro-Chemically Cutting an Irradiated Nuclear Fuel Assembly." Belgian Patent 3,884,784, assignors to Centre d'Etude d'Energie Nucleaire, C.E.N.: E.N.I-Electrische Nijverheids-Installaties, and Belgonuclearie, Brussels, Belgium, July 3, 1972.

*Available for purchase from the National Technical Information Service, Springfield, VA 22161.

**Available for purchase from the NRC/GPO Sales Program, U.S. Nuclear Regulatory Commission, Washington, DC 20555, and/or the National Technical Information Service, Springfield, VA 22161. 

APPENDIX A

DECONTAMINATION METHODS (TABLES) 
AP: Alkaline Permanganate

AC: Ammonium Citrate

citrox: Inhibited CITRate OXalate Reagent

OPG: Oxalic acid, hydrogen Peroxide, Gluconic acio

\section{TABLE A.1. Chemical Methods of Decontamination}

\begin{tabular}{|c|c|c|c|c|c|}
\hline Application & Reagent/Concentration/Process & $\mathrm{DF} / \mathfrak{x}^{*} *$ & Reference & Condition & Comments \\
\hline \multirow[t]{5}{*}{ Aluminum } & 1. $\mathrm{HNO}_{3}$ & & $\begin{array}{l}\text { Ayres } 1971 \\
\text { BNWL-B-90 }\end{array}$ & & $\begin{array}{l}\text { Used on surfaces passivated by oxidizing } \\
\text { acids. }\end{array}$ \\
\hline & $\begin{array}{l}\text { 2. a) Scrub with } \mathrm{Na}-\mathrm{EDTA}+2 \% \text { detergent } \\
\text { rinse b) cover with wet } \mathrm{Na} \text {-EDTA rags } \\
\text { and allow to soak for } 1 \mathrm{hr} \text { c) remove rags } \\
\text { and rinse. }\end{array}$ & $10-1000$ & $\begin{array}{l}\text { Christensen } 1959 \\
\text { LAMS- } 2319\end{array}$ & & \\
\hline & $\begin{array}{l}\text { 3. a) Water rinse b) } 10 \% \text { citric acid } \\
\text { scrub c) } 10 \% \mathrm{HNO}_{3} \text { scrub }\end{array}$ & $100-500$ & $\begin{array}{l}\text { Christensen } 1959 \\
\text { LAMS-2319 }\end{array}$ & & Corrosion nil. \\
\hline & 4. Inhibited sulfamic acid & & $\begin{array}{l}\text { Ayres 1971 } \\
\text { BNWL-B-90 }\end{array}$ & & $\begin{array}{l}\text { Does not promote reprecipitation, no severe } \\
\text { attack at galvanic junctions. }\end{array}$ \\
\hline & 5. $50 \% \mathrm{HNO}_{3}$ & $29-72$ & $\begin{array}{l}\text { Ayres et al. } 1962 \\
\mathrm{HW}-71259\end{array}$ & $70^{\circ} \mathrm{C}$ & \\
\hline \multirow[t]{2}{*}{ Brass } & 6. Nitric acid ( 4 parts acid to 1 part water) & & $\begin{array}{l}\text { Ayres } 7971 \\
\text { BNWL-B-90 }\end{array}$ & $5 \mathrm{sec}$ at $40^{\circ} \mathrm{C}$ & $\begin{array}{l}\text { Also used to remove ceramic fuel residues } \\
\left(\mathrm{PuO}_{2}\right\} \text { from piping systcms. }\end{array}$ \\
\hline & $\begin{array}{l}\text { 7. a) Wipe with acetone or alcohol } \\
\text { b) emery cloth of } 5 \%, A C\end{array}$ & & $\begin{array}{l}\text { Christensen } 1959 \\
\text { LAMS-2319 }\end{array}$ & & \\
\hline \multirow[t]{6}{*}{ Carbon Steel } & $\begin{array}{l}\text { 8. Inhibited } \mathrm{HCl} \text { (propynol, } \\
\text { formaldehyde, inhibitors) }\end{array}$ & & $\begin{array}{l}\text { Ayres } 1971 \\
\text { BNWL-B-90 }\end{array}$ & & $\begin{array}{l}\mathrm{HCl} \text { very corrosive to mild steel, stress cracks } \\
\text { stainless. Typically } 15 \% \mathrm{HCl} \text { and } 1 \% \text { inhibitor } \\
\text { by volume. }\end{array}$ \\
\hline & $\begin{array}{l}\text { 9. } 0.4 \mathrm{M} \text { ammonium oxalate }+0.16 \mathrm{M} \text { citric. } \\
\text { acid }+0.3 \mathrm{M} \mathrm{H}_{2} \mathrm{O}_{2}\end{array}$ & & $\begin{array}{l}\text { Ayres } 1971 \\
\text { BNWL-B-90 }\end{array}$ & $90-95^{\circ} \mathrm{C}$ & $\begin{array}{l}\text { Citric acid complexes the iron ions and } \\
\text { prevents formation of insoluble oxalates. }\end{array}$ \\
\hline & $\begin{array}{l}\text { 10. } 0.5 \% \text { solution of EDTA + citric acid } \\
\text { + hydrazine }\end{array}$ & & $\begin{array}{l}\text { Ayres } 1971 \\
\text { BNWL-B-90 }\end{array}$ & $\mathrm{pH} 6-8,90-100^{\circ} \mathrm{C}$ & \\
\hline & $\begin{array}{l}\text { 11. Buffered oxalic acid }+\mathrm{H}_{2} \mathrm{O}_{2} \\
+ \text { gluconic acid (OPG) }\end{array}$ & & $\begin{array}{l}\text { Divine } 1973 \\
\text { Ayres } 1970\end{array}$ & $80^{\circ} \mathrm{C}, 1-4 \mathrm{hr}$ & $\begin{array}{l}\sim 20 \mathrm{mg} / \mathrm{dm}^{2} \text {-day corrosion. OPG: } 0.025 \mathrm{M} \\
\mathrm{H}_{2} \mathrm{O}_{2}+0.013 \text { gluconic acid. }\end{array}$ \\
\hline & $\begin{array}{l}\text { 12. Inhibited ammonium citrate or } \\
\text { sodium bisulfale: }\end{array}$ & & $\begin{array}{l}\text { Ayres et al. } 1962 \\
\text { HW-71259 }\end{array}$ & & $\begin{array}{l}\text { Corrosion should be less than } 0.2 \text { mils per } \\
\text { cycle. }\end{array}$ \\
\hline & 73. Inhibited $9 \%$ sulfamic acid & & $\begin{array}{l}\text { Ayres } 1966 \\
\text { BNWL-SA-751 }\end{array}$ & & $\begin{array}{l}\text { Typical inhibitors are formaldehyde or } \\
\text { propynol, } 5 \% \text {. }\end{array}$ \\
\hline
\end{tabular}

*DF = decontamination factor; DF unless identified as percent. 
TABLE A.t. (Contd)

\begin{tabular}{|c|c|c|c|c|c|}
\hline Application & Reagent/Concentration/Process & $\mathrm{DF} / \mathrm{K}^{\prime} *$ & Reference & Condition & Comments \\
\hline \multirow[t]{12}{*}{$\begin{array}{l}\text { Carbon Steel } \\
\text { (Contd) }\end{array}$} & $\begin{array}{l}\text { 14. a) Recirculate with AP followed by } \\
\text { water b) recirculate with sodium bisulfate } \\
\text { followed by water }\end{array}$ & $2-300$ & $\begin{array}{l}\text { Ayres et al. } 1962 \\
\text { HW-71259 }\end{array}$ & $60-90^{\circ} \mathrm{C}$ & $\begin{array}{l}\text { If fission products and rupture debris arc } \\
\text { present, precede this process by recirculation } \\
\text { with a solution containing sodium carbonate, } \\
\text { sodium bicarbonate, and hydrogen peroxide. } \\
\text { Sodium bisulfate } 3 \text { to } 10^{2} \% \text { by weight. }\end{array}$ \\
\hline & $\begin{array}{l}\text { 15. OPG followed by an inhibited oxalic- } \\
\text { sulfuric reagent (Sulfox) }\end{array}$ & $10-30$ & $\begin{array}{l}\text { Ayres and Perrigo } 1966 \\
\text { BNWL-SA-666 }\end{array}$ & $\begin{array}{l}\text { OPG: } 80^{\circ} \mathrm{C} \cdot 1-4 \mathrm{hr} \\
\text { Sulfox: } 45-70^{\circ} \mathrm{C} \text {. } \\
1 \mathrm{hr}\end{array}$ & $\begin{array}{l}\text { Sulfox: } 0.3 \mathrm{M} \mathrm{H}_{2} \mathrm{SO}_{4}+0.1 \mathrm{M} \mathrm{H}_{2} \mathrm{C}_{2} \mathrm{O}_{4}+1 \mathrm{~g} / \mathrm{I} \\
\text { inhibitor (phenylthiourea). OPG: } 0.025 \mathrm{M} \\
\mathrm{H}_{2} \mathrm{C}_{2} \mathrm{O}_{4}+0.5 \mathrm{M} \mathrm{H} \mathrm{H}_{2} \mathrm{O}_{2}+0.013 \mathrm{M} \text { gluconic acid. }\end{array}$ \\
\hline & 16. APAC & $90-99 \%$ & $\begin{array}{l}\text { Abrams and Salterelli } \\
\text { 1966, WAPD-299 }\end{array}$ & $250^{\circ} \mathrm{F}$ for $24 \mathrm{hr}$ & $\begin{array}{l}\text { AP: } 2.5 \mathrm{M} \mathrm{NaOH}+0.2 \mathrm{M} \mathrm{KMnO}_{4} \\
\text { AC: } 0.4 \mathrm{M}\left(\mathrm{NH}_{4}\right)_{2} \mathrm{HC}_{6} \mathrm{H}_{5} \mathrm{O},(\mathrm{AC}) .\end{array}$ \\
\hline & $\begin{array}{l}\text { 17. } 10 \% \mathrm{NaOH}+3 \%, \mathrm{KMnO}_{4} \text { followed by } \\
\mathrm{H}_{2} \mathrm{C}_{2} \mathrm{O}_{4} 25 \mathrm{~g} / \mathrm{I}+\left(\mathrm{NH}_{4}\right)_{2} \mathrm{HC}_{6} \mathrm{H}_{7} \mathrm{O}_{7} 50 \mathrm{~g} / \mathrm{I}+ \\
\mathrm{Fe}_{2} 2 \mathrm{~g} / \mathrm{I}+\mathrm{ml} \text { diethylthiourea } 1 \mathrm{~g} / \mathrm{l} \\
\mathrm{Fe}_{2}\left(\mathrm{SO}_{4}\right)_{3}\end{array}$ & $11-360$ & $\begin{array}{l}\text { Weed } 1968 \\
\text { BNWL-711 }\end{array}$ & $\begin{array}{l}105^{\circ} \mathrm{C} \text { and about } \\
80^{\circ} \mathrm{C}\end{array}$ & $\begin{array}{l}\text { Report provides a comparison of corrosion } \\
\text { data for Haynes } 25,305 \text {, and } 316 \mathrm{SS}, 17-4 \mathrm{pH} \\
\text { SS, } 440 \text { SS. A272 carbon steet, and orhers. }\end{array}$ \\
\hline & $\begin{array}{l}\text { 18. } 0.3 \mathrm{M} \mathrm{H}_{2} \mathrm{SO}_{4}+0.1 \mathrm{M} \text { oxalic acid } \\
\text { + phenylthiourea ( } 5 \text { ulfox) }\end{array}$ & $3-4$ & Ayres 1970 & $25^{\circ} \mathrm{C}, 40 \mathrm{~min}$ & \\
\hline & 19. $0.4 \mathrm{wt} \%$ NUTEK L-106 & 6 & $\begin{array}{l}\text { Lit. Review of Chem., } \\
\text { Water Cooled Nuclear } \\
\text { Decon Processes for } \\
\text { Reactors NP-1033 }\end{array}$ & $100^{\circ} \mathrm{C}$ & $\begin{array}{l}\text { May nol be applicable to U.S. reactors } \\
\text { because of construction material differences. }\end{array}$ \\
\hline & $\begin{array}{l}\text { 20. Buffered mixture of oxalic acid and } \\
\text { hydrogen peroxide }\end{array}$ & & $\begin{array}{l}\text { Ayres } 1966 \\
\text { BNWL-SA-75i }\end{array}$ & $80^{\circ} \mathrm{C}, 1-4 \mathrm{hr}$ & $0.025 \mathrm{M}$ oxalic acid, $0.5 \mathrm{M} \mathrm{H}_{2} \mathrm{O}_{2}$ \\
\hline & 21. NS-1 & $2-10$ & $\begin{array}{l}\text { Remark } 1979 \\
\text { RDTPL-79-35 }\end{array}$ & & $\begin{array}{l}\text { NS-1 is a proprielary product of Dow } \\
\text { Chemical Company. }\end{array}$ \\
\hline & $\begin{array}{l}\text { 22. a) Water rinse b) scrub with } 10 \% \text { citric } \\
\text { acid }+5 \% \text { detergent; rinse c) scrub witb } \\
0.3 \mathrm{M} \text { citric acid }+0.1 \% \text {, detergent }+0.5 \mathrm{M} \\
\mathrm{HCl} \text { rinse di scrub with } 6 \mathrm{M} \mathrm{HNO}_{3} \\
\text { e) repeat d) as necessary }\end{array}$ & 20 & $\begin{array}{l}\text { Christensen } 1959 \\
\text { LAMS- } 2319\end{array}$ & & \\
\hline & $\begin{array}{l}\text { 23. } 0.0017 \mathrm{M} \text { EDTA }+0.00119 \mathrm{M} \text { citric acid } \\
+0.00198 \mathrm{M} \text { oxalic acid }\end{array}$ & 2 & $\begin{array}{l}\text { Kratzer } 1979 \\
\text { UNI- } 1425\end{array}$ & $\begin{array}{l}100^{\circ} \mathrm{C}, 70 \mathrm{l} / \mathrm{m} \text { flow } \\
\mathrm{pH} 4.8\end{array}$ & $\sim 1000 \mathrm{mg} / \mathrm{dm}^{2}-\mathrm{d}$ corrosion $(13 \mu \mathrm{m} / \mathrm{d})$ \\
\hline & $\begin{array}{l}\text { 24. } 0.0017 \mathrm{M} \text { EDTA }+0.00119 \mathrm{M} \text { citric acid } \\
+0.00198 \mathrm{M} \text { oxalic acid }\end{array}$ & $\begin{array}{l}16 \gamma \\
110 \beta+\gamma\end{array}$ & $\begin{array}{l}\text { Kratzer } 1979 \\
\text { UNI- } 1425\end{array}$ & $\begin{array}{l}100^{\circ} \mathrm{C}, 70 \mathrm{I} / \mathrm{m} \text { flow } \\
\mathrm{pH} 2.2\end{array}$ & $\curvearrowright 1500 \mathrm{mg} / \mathrm{dm}^{2}-\mathrm{d}$ corrosion $(18.5 \mu \mathrm{m} / \mathrm{d})$ \\
\hline & $\begin{array}{l}\text { 25. } 0.002 \mathrm{M} \text { HEEDTA }+0.002 \mathrm{M} \text { citric acid } \\
+0.002 \mathrm{M} \text { ascorbic acid }\end{array}$ & $\begin{array}{l}25 \gamma \\
500 \gamma+\beta\end{array}$ & $\begin{array}{l}\text { Kratzer } 7979 \\
\text { UNI-1425 }\end{array}$ & $\mathrm{pH} 2.6$ & $\cdots 20-600 \mathrm{mg} / \mathrm{dm}^{2}-\mathrm{d}$ corrosion $(0.2-7.5 \mu \mathrm{mt} / \mathrm{d})$ \\
\hline
\end{tabular}


TABLE A.1. (Contd)

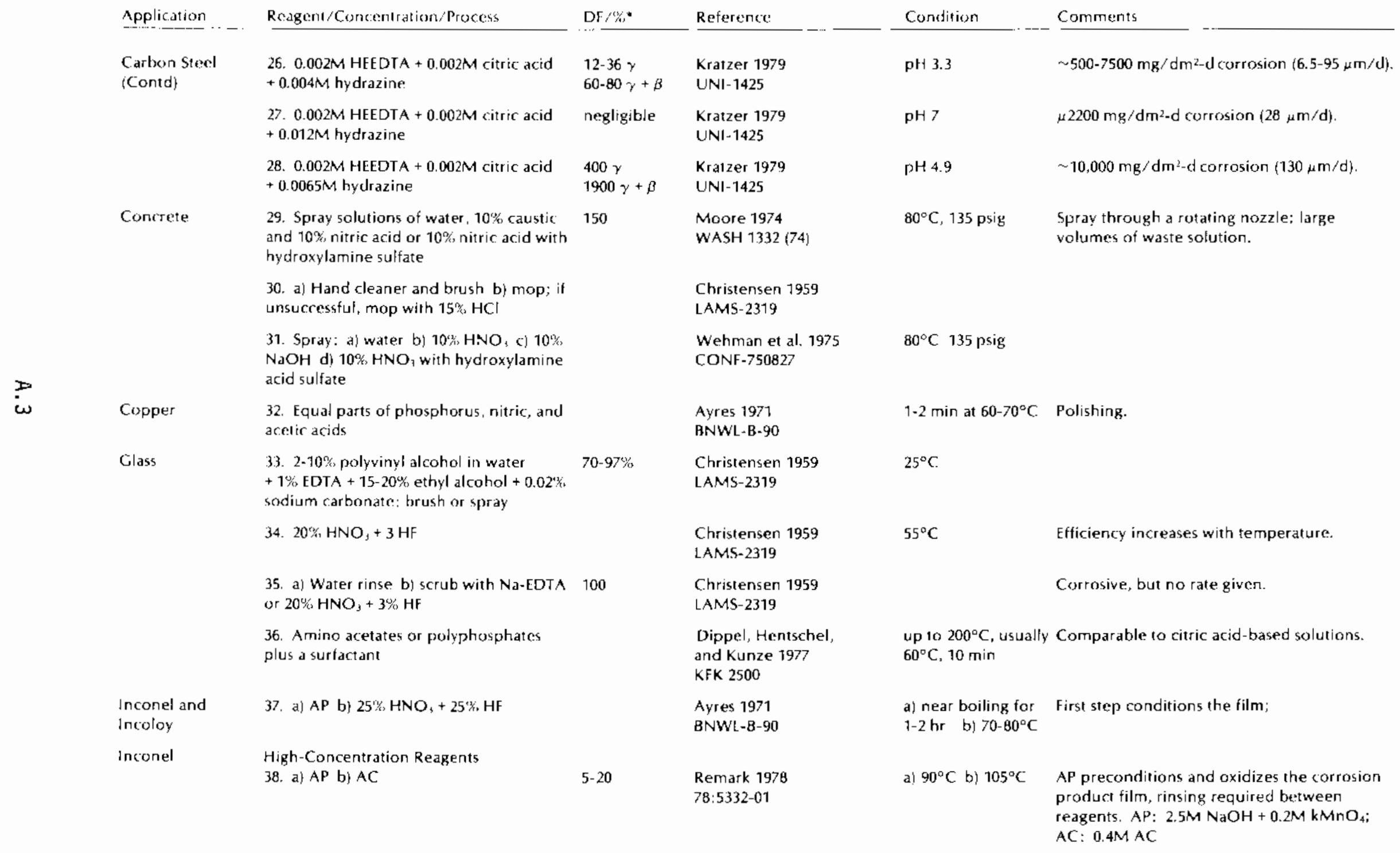


TABLE A.1. (Contd)

\begin{tabular}{|c|c|c|c|c|c|}
\hline Application & Reagent/Concentration/Process & $\mathrm{DF} / \%^{*}$ & Reference & Condition & Comments \\
\hline \multirow[t]{11}{*}{$\begin{array}{l}\text { Inconel } \\
\text { (Contd) }\end{array}$} & 39. a) AP b) oxalic acid & $5-20$ & $\begin{array}{l}\text { Remark } 1978 \\
78: 5332-01\end{array}$ & a) $90^{\circ} \mathrm{C}$ & $\begin{array}{l}\text { AP: } 2.5 \mathrm{M} \mathrm{NaOH}+0.2 \mathrm{M} \mathrm{KMnO}_{4} ; \\
\text { oxalic acid: } 0.025 \mathrm{M} \text {. }\end{array}$ \\
\hline & 40. a) AP b) oxalic acid c) AC & $5-20$ & $\begin{array}{l}\text { Remark } 1978 \\
78: 5332-01\end{array}$ & a) $90^{\circ} \mathrm{C}$ & $\begin{array}{l}\text { Step ch prevents redeposition of oxalate } \\
\text { precipitates, concentrations the same as in } \\
\text { numbers } 38 \text { and } 39 \text { above. }\end{array}$ \\
\hline & 41. a) AP b) citrox & $20-240$ & $\begin{array}{l}\text { Remark } 1978 \\
78: 5332-01\end{array}$ & a) $90^{\circ} \mathrm{C}$ & $\begin{array}{l}1.5 \text { to } 2 \text { mils corrosion of stainless steel per } \\
\text { application: } 1.5 \text { mils } / \text { hr on carbon steel. } \\
\text { Citrox: } 0.2 \mathrm{M} \text { citric acid }+0.3 \mathrm{M} \text { oxalic acid. }\end{array}$ \\
\hline & Low-Concentration Reagents & & $\begin{array}{l}\text { Remark } 7978 \\
78: 6332-01\end{array}$ & & $\begin{array}{l}\text { All reagents less than } 2000 \mathrm{ppm}(0.2 \%) \text {; } \\
\text { regenerate in cation exchange columns. }\end{array}$ \\
\hline & 42. NUTEK L-106 & $2-12$ & $\begin{array}{l}\text { Remark } 1978 \\
78: 6332-01\end{array}$ & & $\begin{array}{l}1-4 \text { days for total PWR primary system } \\
\text { decontamination. }\end{array}$ \\
\hline & $\begin{array}{l}\text { 43. Chelating agents such as EDTA, } \\
\text { citric acid, and oxalic acid }\end{array}$ & & $\begin{array}{l}\text { Remark } 1978 \\
78: 6332-01\end{array}$ & & \\
\hline & 44. Hydrazine & 1.3 expected & $\begin{array}{l}\text { Remark } 1978 \\
78: 6332-01\end{array}$ & & $\begin{array}{l}\text { Enhances solubility of crud deposils: use as a } \\
\text { dilute solution in fill-soak-drain method } \\
\text { 1-2 weeks preparation, } 8-24 \mathrm{hr} \text { for } \\
\text { decontamination. }\end{array}$ \\
\hline & 45. Hydrogen peroxide & 2-6 expected & $\begin{array}{l}\text { Rernark } 1978 \\
78: 6332-01\end{array}$ & less than $70^{\circ} \mathrm{C}$ & $\begin{array}{l}\text { Concentrations in low ppm range; will not } \\
\text { solubilizc iron. }\end{array}$ \\
\hline & $\begin{array}{l}\text { 46. Hydrogen peroxide plus chelant } \\
\text { (EDTA) }\end{array}$ & $2-15$ cxpected & $\begin{array}{l}\text { Remark } 1978 \\
78: 6332-01\end{array}$ & $100^{\circ} \mathrm{C}$ & $\begin{array}{l}\text { Chelant will solubilize iron; fill-soak-drain } \\
\text { method. }\end{array}$ \\
\hline & 47. Hydrogen peroxide-hydrazine & $2-8$ expected & $\begin{array}{l}\text { Remark } 1978 \\
78: 6332-01\end{array}$ & $\begin{array}{l}100^{\circ} \mathrm{C}, \text { fill-soak- } \\
\text { drain, } 1-2 \text { days }\end{array}$ & $\begin{array}{l}\mathrm{H}_{2} \mathrm{O}_{2} \text { solubilizes } \mathrm{Co}-58 \text { and nickel, but not } \\
\text { iron. Hydrazine reduces from the more } \\
\text { soluble divalent state. No rinses between } \\
\text { solutions required. }\end{array}$ \\
\hline & $\begin{array}{l}\text { 48. } 0.0017 \mathrm{M} \text { EDIA }+0.00114 \mathrm{M} \text { citric acid } \\
+0.00198 \mathrm{M} \text { oxalic acid }\end{array}$ & 2 & $\begin{array}{l}\text { Kratzer } 1979 \\
\text { UNI-1425 }\end{array}$ & $\begin{array}{l}100^{\circ} \mathrm{C}, 70 \mathrm{l} / \mathrm{m} \text { flow } \\
\mathrm{pH} 4.8\end{array}$ & Negligible corrosion. \\
\hline Monel and Nickel & 49. $25 \%$ sulfamic acid & & $\begin{array}{l}\text { Ayres } 1971 \\
\text { BNWL-B-90 }\end{array}$ & $1 \mathrm{hr}$ at boiling & Metal exposed to water at $570^{\circ} \mathrm{F}$ or lower. \\
\hline Stainless Steel & $\begin{array}{l}\text { 50. Amino acetates or polyphosphates } \\
\text { plus a surfactant }\end{array}$ & & $\begin{array}{l}\text { Dippel, Hentschel, } \\
\text { and Kunze } 1977 \\
\text { KFK } 2500\end{array}$ & $\begin{array}{l}\text { Up to } 200^{\circ} \mathrm{C} \text {, } \\
\text { usually } 60^{\circ} \mathrm{C} \text {, } \\
10 \mathrm{~min}\end{array}$ & Comparable to citric acid-based solutions. \\
\hline
\end{tabular}


TABLE A.1. (Contd)

\begin{tabular}{|c|c|c|c|c|c|}
\hline Application & Reagent/Concenlralion/Process & DF $/ \% *$ & Reference & Condition & Comments \\
\hline \multirow[t]{14}{*}{$\begin{array}{l}\text { Stainless Stcel } \\
\text { (Contd) }\end{array}$} & $\begin{array}{l}\text { 51. a) AP b) sulfuric acid + diammonium } \\
\text { citrate }\end{array}$ & 10 & $\begin{array}{l}\text { Remark and Miller } \\
\text { 1979, RDTPL-79-35 }\end{array}$ & $A P$ at $90^{\circ} \mathrm{C}$ & $\begin{array}{l}\text { a) } \mathrm{AP}: 10 \% \mathrm{NaOH}+3 \% \mathrm{KMnO}_{4} \text { b) } 0.3 \mathrm{M} \\
\mathrm{H}_{2} \mathrm{SO}_{4}+0.2 \mathrm{M}\left(\mathrm{NH}_{4}\right)_{2} \mathrm{HC}_{6} \mathrm{H}_{5} \mathrm{O}_{7}\end{array}$ \\
\hline & $\begin{array}{l}\text { 52. Soak in a solution of ammonium } \\
\text { oxalate. citrate, hydrofluoric acid. } \\
\text { and hydrogen peroxide }\end{array}$ & $400-1700$ & $\begin{array}{l}\text { Platt } 1975 \\
\text { BNWL-1952 Section } 5\end{array}$ & $\mathrm{pH} \mathrm{2-4}$ & $\begin{array}{l}0.4 \mathrm{M} \mathrm{AC,} 0.4 \mathrm{M} \text { ammonium oxalate, } 0.5 \mathrm{M} \mathrm{HF} \text {, } \\
0.02 \mathrm{M} \mathrm{H}_{2} \mathrm{O}_{2}\end{array}$ \\
\hline & 53. AP-citrox & $20-30$ & $\begin{array}{l}\text { Ayres } 1966 \\
\text { BNWL-SA-751 } \\
\text { BNWL-SA-666 }\end{array}$ & $\begin{array}{l}\text { AP: } 105^{\circ} \mathrm{C} \text { for } 2 \mathrm{hr} \\
\text { Acid: } 80^{\circ} \mathrm{C} \text { for } 2 \mathrm{hr} \\
\text { or longer }\end{array}$ & $\begin{array}{l}\text { AP, } 25 \mathrm{M} \mathrm{NaOH}+0.2 \mathrm{M} \mathrm{KMnO}_{4} \text {; citrox: an } \\
\text { inhibited mixture of citric and oxalic acids, } \\
0.2 \mathrm{M} \text { citric acid }+0.3 \mathrm{M} \text { oxalic acid; principally } \\
{ }^{6} \mathrm{Co} \text { contamination. }\end{array}$ \\
\hline & $\begin{array}{l}\text { 54. Acidify coolant with boric acid and } \\
\text { maintain reducing environment with } \mathrm{H}_{2}\end{array}$ & & $\begin{array}{l}\text { 1.jt. Review of Chem. } \\
\text { Decon Processes for }\end{array}$ & Cool system & $\begin{array}{l}\text { May not be applicabie to U.S. reactors } \\
\text { because of construction material differences. }\end{array}$ \\
\hline & $\begin{array}{l}\text { 55. a) citrox b) AP c) nitric-oxalic } \\
\text { and dilute citrox }\end{array}$ & $3-120$ & $\begin{array}{l}\text { Water Cooled Nuclear } \\
\text { Reactors NP:1033 }\end{array}$ & & $\begin{array}{l}\text { Citrox: } 0.2 \mathrm{M} \text { citric acid }+0.3 \mathrm{M} \text { oxalic acid; } \\
\text { dilute citrox: } 0.03 \mathrm{M} \text { citric acid }+0.02 \mathrm{M} \text { oxalic } \\
\text { acid; } 0.2 \mathrm{M} \text { nitric acid. }\end{array}$ \\
\hline & 56. $20 \% \mathrm{HNO}_{3}+30 \% \mathrm{HF}$ & & $\begin{array}{l}\text { Ayres } 1971 \\
\text { BNWL-B-90 }\end{array}$ & $55-65^{\circ} \mathrm{C}$ & \\
\hline & $\begin{array}{l}\text { 57. } 6.5 \% \mathrm{H}_{2} \mathrm{SO}_{4}+6.5 \% \mathrm{HF}+87 \% \mathrm{H}_{2} \mathrm{O} \\
+250 \mathrm{Cr}_{2} \mathrm{O}_{3}\end{array}$ & & $\begin{array}{l}\text { Ayres } 1971 \\
\text { BNWL-B-90 }\end{array}$ & $\begin{array}{l}\text { Elevated or room } \\
\text { temperature }\end{array}$ & \\
\hline & $\begin{array}{l}\text { 58. a) AP b) ditule complexing agent or } \\
\text { dilute acid }\end{array}$ & & $\begin{array}{l}\text { Ayres } 1971 \\
\text { BNWL-B-90 }\end{array}$ & $90^{\circ} \mathrm{C}$ & $\begin{array}{l}\text { First step conditions the film; dilute is less } \\
\text { than } 2000 \mathrm{ppm} \text {. }\end{array}$ \\
\hline & 59. EDTA + citric acid hydrazinc: & & $\begin{array}{l}\text { Ayres } 1971 \\
\text { BNWL-B-90 }\end{array}$ & $\mathrm{pH} 6-8,90-100^{\circ} \mathrm{C}$ & \\
\hline & $\begin{array}{l}\text { 60. } 0.4 \mathrm{M} \mathrm{H} \mathrm{H}_{2} \mathrm{C}_{2} \mathrm{O}_{4}+0.1 \mathrm{MHF}+0.0-1.0 \mathrm{M} \\
\mathrm{H}_{2} \mathrm{O}_{2}\end{array}$ & & $\begin{array}{l}\text { Ayres } 1971 \\
\text { BNWL-B-90 }\end{array}$ & $2-4 \mathrm{hr}$ at $90-95^{\circ} \mathrm{C}$ & $\begin{array}{l}\text { Peroxide promotes corrosion in lower } \\
\text { concentration, inhibits at higher. }\end{array}$ \\
\hline & $\begin{array}{l}\text { 61. a) } 0.2 \% \text { oxalic acid b) add } 5 \mathrm{ml} \text { of } \\
30 \% \mathrm{H}_{2} \mathrm{O}_{2} \text { per liter }\end{array}$ & 300 & $\begin{array}{l}\text { Ayres } 1971 \\
\text { BNWL-B-90 and } 1966 \\
\text { BNWL-SA-751 }\end{array}$ & $15 \mathrm{~min}$ at $35^{\circ} \mathrm{C}$ & Polishing, derusting, and decontaminating. \\
\hline & $\begin{array}{l}\text { 62. EDTA (or NTA, DPTA, TTHA) + citric } \\
\text { acid }\end{array}$ & & $\begin{array}{l}\text { Ayres } 1971 \\
\text { BNWL-B-90 }\end{array}$ & 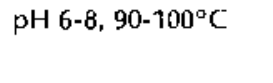 & $\begin{array}{l}\text { Rate increases with temperature; regulate } \mathrm{pH} \\
\text { with hydrazine; definitions given in text. }\end{array}$ \\
\hline & $\begin{array}{l}\text { 63. } 70-80 \% \mathrm{H}_{3} \mathrm{PO}_{4} \text { or chromous sulfate } \\
\text { solution }\left(0.4 \mathrm{M} \mathrm{Cr} \mathrm{SO} \mathrm{S}_{4}+0.5 \mathrm{M} \mathrm{H}_{2} \mathrm{SO}_{4}\right)\end{array}$ & & $\begin{array}{l}\text { Ayres } 1971 \\
\text { BNWL-B-90 }\end{array}$ & $85^{\circ} \mathrm{C}$ & \\
\hline & 64. $\mathrm{KCl} / \mathrm{NaCl} / \mathrm{AlCl}_{3}$ (salt melts) & $96 \%$ & Dippel 1976 & $130^{\circ} \mathrm{C}, 45 \mathrm{~min}$ & $\begin{array}{l}\text { Some salt melts limited by their corrosive } \\
\text { properties. }\end{array}$ \\
\hline
\end{tabular}


TABLE A.1. (Contd)

\begin{tabular}{|c|c|c|c|c|c|}
\hline Application & Reagent/Concentration/Process & $\mathrm{DF} / \% *$ & Reference & Condilion & Comments \\
\hline \multirow[t]{12}{*}{$\begin{array}{l}\text { Stainless Steel } \\
\text { (Contd) }\end{array}$} & 65. NS-1 & $5-8$ & $\begin{array}{l}\text { Rohner, Summary } \\
\text { ANS Trans. } \\
\text { November } 1978\end{array}$ & $120^{\circ} \mathrm{C}, 100 \cdot 200 \mathrm{hr}$ & Extensive preparation time required. \\
\hline & $\begin{array}{l}\text { 66. } 1.0 \mathrm{M} \text { oxalic acid }+0.02 \mathrm{M} \mathrm{H}_{2} \mathrm{O} \text {, } \\
+0.013 \mathrm{M} \text { gluconic acid }\end{array}$ & & Divine 1973 & & $\therefore 20 \mathrm{mg} / \mathrm{dm}^{2}-\mathrm{d}$ corrosion \\
\hline & $\begin{array}{l}\text { 67. Oxalic peroxide (OPG) followed } \\
\text { by sultur }\end{array}$ & $10-30$ & $\begin{array}{l}\text { Ayres and Perrigo } 7966 \\
\text { BNWL-SA-666 }\end{array}$ & & $\begin{array}{l}\text { Sulfox: } 0.3 \mathrm{MH}_{2} \mathrm{SO}_{4}+0.1 \mathrm{M} \mathrm{H}_{2} \mathrm{C}_{2} \mathrm{O}_{4}+1 \mathrm{~g} / \mathrm{l} \\
\text { inhibitor; } \mathrm{OPG}: 0.025 \mathrm{M} \mathrm{H}_{2} \mathrm{C}_{2} \mathrm{O}_{4}+0.5 \mathrm{H}_{2} \mathrm{O}_{2}+ \\
0.013 \mathrm{M} \text { gluconic acid. }\end{array}$ \\
\hline & $\begin{array}{l}\text { 68. } 2-10 \% \text {, polyvinyl alcohol in water }+1 \% \\
\text { EDTA }+15-20 \% \text { ethyl alcohol }+0.02 \% \\
\text { sodium carbonate; brush or spray }\end{array}$ & $70-97 \%$ & Dippel 1976 & $60^{\circ} \mathrm{C}$ & \\
\hline & 69. a) $A P$ b) $A C$ & & $\begin{array}{l}\text { Remark } 1978 \\
78: 6332-01\end{array}$ & a) $90^{\circ} \mathrm{C}$ b) $105^{\circ} \mathrm{C}$ & $\begin{array}{l}\text { AP preconditions and oxidizes the corrosion } \\
\text { product film, rinsing reguired belween } \\
\text { reagents. AC prevents redeposition of } \\
\text { oxalate precipitate. }\end{array}$ \\
\hline & 70. a) AP b) oxalic acid & & & a) $90^{\circ} \mathrm{C}$ & \\
\hline & 71. a) AP b) oxalic acid c) $A C$ & & & a) $90^{\circ} \mathrm{C}$ & $\begin{array}{l}\text { AP, } A C \text {, and oxalic acid concentrations as } \\
\text { before. }\end{array}$ \\
\hline & 72. a) AP b) citrox & & & a) $90^{\circ} \mathrm{C}$ & $\begin{array}{l}1.5 \mathrm{to} 2 \mathrm{mils} \text { corrosion of stainless steel per } \\
\text { application: } 1.5 \mathrm{mu} / \mathrm{s} / \mathrm{hr} \text { on carbon steei. }\end{array}$ \\
\hline & 73. $1 \mathrm{M} \mathrm{HNO}_{3}$ & & $\begin{array}{l}\text { Ayres } 1971 \\
\text { BNWL-B-90 }\end{array}$ & & $\begin{array}{l}\text { Used on surfaces passivated by oxidizing } \\
\text { acids. }\end{array}$ \\
\hline & 74. Salt mixes & $90-95 \%$ & $\begin{array}{l}\text { Dippel, Hentschel. } \\
\text { and Kunze } 1976 \\
\text { KFK } 2375\end{array}$ & $1-2 \mathrm{hr}$ & $\begin{array}{l}\text { Cleansing pasles prepared by mixing } \\
\text { combinations of } \mathrm{HF}, \mathrm{HNO}_{3} \text {, and } \mathrm{HCI} \text { with a } \\
\text { hydrofluoric acid-resistant, highly dispersed } \\
\text { baryte type material such as a } \mathrm{KH}_{2} \mathrm{PO}_{4} \text { molten } \\
\text { salt. }\end{array}$ \\
\hline & 75. AP followed by nitric acid & & $\begin{array}{l}\text { Ayres, Perrigo, } \\
\text { and Weed } 1966 \\
\text { BNWL-5A-938 }\end{array}$ & & $A P: \quad 10-18 \% \mathrm{NaOH}+3 \% \mathrm{KM}_{4} \mathrm{O}_{4} ; 10 \% \mathrm{HNO}_{2}$ \\
\hline & 76. AP followed by AC (APAC) & & $\begin{array}{l}\text { Ayres, Perrigo, } \\
\text { and Weed } 1966 \\
\text { BNWL-SA-938 }\end{array}$ & $\begin{array}{l}\text { AP: } 105^{\circ} \mathrm{C} \text { for } 1 \mathrm{hr} \\
\mathrm{AC}: 80^{\circ} \mathrm{C} \text { for } 1 \mathrm{hr}\end{array}$ & $\begin{array}{l}\text { Ineffective on stainless films exposed to } 250 \text { - } \\
300^{\circ} \mathrm{C} \text { water for extended periods, } \\
\text { concentrations as before. }\end{array}$ \\
\hline
\end{tabular}


TABLE A.1. (Contd)

\begin{tabular}{|c|c|c|c|c|c|}
\hline Application & Reagent/Conccontration/Process & $\mathrm{DF} / \mathrm{k}^{\prime} *$ & Reference & Condition & Comments \\
\hline \multirow[t]{11}{*}{$\begin{array}{l}\text { Stainless Steel } \\
\text { (Contd) }\end{array}$} & 77. AP-citrox & & $\begin{array}{l}\text { Ayres. Perrigo, } \\
\text { and Weed } 1966 \\
\text { BNWL-SA-938 }\end{array}$ & & Concentrations as before. \\
\hline & $\begin{array}{l}\text { 78. AP followed by mixture of } 3 \% \text { TTHA, } \\
\text { citric acid, } V_{3} \mathrm{H}_{4} \text {, and } \mathrm{NH}_{3} \mathrm{OH}\end{array}$ & $\begin{array}{l}20 \text { at } 30 \mathrm{sec} \\
250 \text { at } 5 \mathrm{~min} \\
4000 \text { at } 1 \mathrm{hr}\end{array}$ & $\begin{array}{l}\text { Ayres } 1966 \\
\text { BNWI-SA-2460 }\end{array}$ & $98^{\circ} \mathrm{C}, \mathrm{pH} 7-8$ & $\begin{array}{l}\text { EDTA can replace TTHA. } 0.2 \mathrm{M} \text { citric acid, } \\
0.01 \mathrm{M} N \mathrm{H}_{i}, 0.1 \mathrm{M} \mathrm{NH}, \mathrm{OH} \text {. }\end{array}$ \\
\hline & $\begin{array}{l}\text { 79. } 0.0017 \mathrm{M} \text { EDTA }+0.00119 \mathrm{M} \text { citric acid } \\
+0.00198 \mathrm{M} \text { oxalic acid }\end{array}$ & 2 & $\begin{array}{l}\text { Kralzer } 1979 \\
\text { UNI-1425 }\end{array}$ & $\begin{array}{l}100^{\circ} \mathrm{C}, 701 / \mathrm{min} \\
\text { flow. } \mathrm{pH} 4.8\end{array}$ & $\sim 0.56 \mathrm{mg} / \mathrm{dm}^{2}-\mathrm{d}$ corrosion $\{0.08 \mu \mathrm{m} / \mathrm{d}\}$ \\
\hline & $\begin{array}{l}\text { 80. } 0.0017 \mathrm{M} \text { EDTA }+0.00119 \mathrm{M} \text { cilric acid } \\
+0.00198 \mathrm{M} \text { oxalic acid }\end{array}$ & $\begin{array}{l}16 \gamma \\
160 \gamma+\beta\end{array}$ & $\begin{array}{l}\text { Kratzer } 1979 \\
\text { UNI- } 1425\end{array}$ & $\begin{array}{l}100^{\circ} \mathrm{C}, 170 \mid / \mathrm{min} \\
\text { flow, pH } 2.2\end{array}$ & $\sim 261 \mathrm{mg} / \mathrm{dm} \mathrm{m}^{2}-\mathrm{d}$ corrosion $(3.3 \mu \mathrm{m} / \mathrm{d})$ \\
\hline & $\begin{array}{l}\text { 81. } 0.002 \mathrm{M} \text { HEEDTA }+0.002 \mathrm{M} \text { citric acid } \\
+0.004 \mathrm{M} \text { Hydrazine }\end{array}$ & $\begin{array}{l}12-36 \gamma \\
60-80 \gamma+\beta\end{array}$ & $\begin{array}{l}\text { Kratzer } 1979 \\
\text { UNI- } 1425\end{array}$ & $\mathrm{pH} 3.3$ & $-200 \mathrm{mg} / \mathrm{dm} \mathrm{m}^{2}-\mathrm{d}$ corrosion $(4.6 \mu \mathrm{m} / \mathrm{d})$ \\
\hline & $\begin{array}{l}\text { 82. Spray solutions of water, } 10 \% \text { caustic, } \\
\text { and } 10 \% \text { nitric acid or } 10 \% \text { nitric acid with } \\
\text { hydroxylamine sulfate }\end{array}$ & 150 & $\begin{array}{l}\text { Moore } 1974 \\
\text { WASH } 1332(74)\end{array}$ & $80^{\circ} \mathrm{C}, 135$ psig & $\begin{array}{l}\text { Spray through a rotating nozzle, large } \\
\text { volumes of waste solution. }\end{array}$ \\
\hline & 83. a) $1.0 \mathrm{M}$ oxalic acid b! AP c) citrox & & $\begin{array}{l}\text { Oertal et al. } 1978 \\
\text { BNWL-TR- } 290\end{array}$ & & Rheinsberg plant. \\
\hline & B4. AP & 0 & Meservey 1970 & $105^{\circ} \mathrm{C}, 24 \mathrm{hr}$ & $\begin{array}{l}\text { An oxidizing agent that reacts with the } \\
\text { chromium in the corrosion film, converting it } \\
\text { to an oxide, which is dissolved by the alkaline } \\
\text { solution. Normally used in a multistep } \\
\text { process. Not corrosive to stainless steel; } \\
\text { mildly corrosive to carbon steel, AP; } 10 \% \\
\mathrm{NaOH}+3 \%, \mathrm{KMnO}_{4} \text {. }\end{array}$ \\
\hline & 85. AP-cilrox & 20 & Ayres 1970 & $\begin{array}{l}\text { AP at } 110^{\circ} \mathrm{C} \text {, citrox } \\
\text { at } 80^{\circ} \mathrm{C}, 24 \mathrm{hr}\end{array}$ & $\begin{array}{l}\text { Citrox is a mixture of citric and oxalic acids } \\
\text { plus an inhibitor. Citrox neutralizes residual } \\
\text { AP, dissolves } \mathrm{MnO}_{2} \text {, and complexes the iron } \\
\text { oxides. Concentrations as before. }\end{array}$ \\
\hline & 86. AP followed by oxalic acid (APOX) & 16 & Meservey 1970 & $\begin{array}{l}\text { AP at } 105^{\circ} \mathrm{C}, O \mathrm{OX} \text { at } \\
85^{\circ} \mathrm{C}, 24 \mathrm{hr}\end{array}$ & $\begin{array}{l}\text { Useful for aged films on high-temperature } \\
\text { slainless steel. } 0.9 \mathrm{M} \text { oxalic acid. }\end{array}$ \\
\hline & 87. AP followed by sulfamic acid (AP-Sul) & 20 & Ayres 1970 & $\begin{array}{l}\mathrm{AP} \text { at } 105^{\circ} \mathrm{C} \text {. Sul at } \\
70^{\circ} \mathrm{C}, 24 \mathrm{hr}\end{array}$ & $\begin{array}{l}\text { Similar in effectiveness to AP-citrox. Used on } \\
\text { stainless steel. carbon stecl, and aluminum. } \\
0.9 \mathrm{M} \text { sulfamic acid. }\end{array}$ \\
\hline
\end{tabular}


TABLE A.1. (Contd)

\section{Application \\ Stainless Sree}

(Contd)
DF $/ \% *$

2 with redep. Ayres 1970 50 with no

redep.
92. EDTA

93. HEDTA

94. Hydrochloric acid (HC)

95. Nitric acid ( $\mathrm{HNO}_{3}$ )

96. NS-1

97. Nitriloacetic acid (NTA)
50

5-15

$80-90 \%$

$80-90 \%$

\section{Ayres 1970}

Manion 1980

Johnson et al 1979 BN-5A-970

Oertal et al. 1978

BNWL-TR-290

Iohnson 1979

BN-\$A-770

80-90\%

Johnson et al. 1979

BN-SA-970

Loucks 1977

10

10

Carlson 1970

Dow 1970

2-12

$80-90 \%$

Condition

$120^{\circ} \mathrm{C}, 48 \mathrm{hr}$

In dilute form the $A C$ removes residual $\mathrm{MnO}_{2}$ from the AP solution and neutralizes that solution. In concentrated form the AC attacks the remaining corrosion film. Redeposition is a problem. Not corrosive to stainless steel; corrosive to carbon steel. 0.4M AC.

$120^{\circ} \mathrm{C}, 48 \mathrm{hr}$

$85-125^{\circ} \mathrm{C}, \mathrm{pH} 3.5$

$150^{\circ} \mathrm{C}, \mathrm{pH} 3.5$

$100^{\circ} \mathrm{C}$

90-180 $\mathrm{C}, \mathrm{pH} 3.5-7$ $130^{\circ} \mathrm{C}$, pH 5.5 with $\mathrm{NH}_{4} \mathrm{OH}$

$70^{\circ} \mathrm{C} .2 \mathrm{hr}$

$75^{\circ} \mathrm{C}, 1 \mathrm{hr}$

$120^{\circ} \mathrm{C}, 100-200 \mathrm{~h}$

$180^{\circ} \mathrm{C}, \mathrm{pH} 5.5$
$0.002 \mathrm{M}$ EDTA added to prevent redeposition of iron oxides. AP: $10 \% \mathrm{NaOH}+3 \% \mathrm{KMnO}_{4}$.

A mixture of weak acids and a chelating agent, can be modified for higher DFs, $0.1 \mathrm{wt} \%$.

$0.0005 \mathrm{M}$ citric acid.

$0.00002 \mathrm{M}$ to 0.002

$0.002 \mathrm{M}$

Applicable only when no subsequent use is expected because of high corrosiveness. Has been used with stainless steel, Cr-Mo steel, carbon steel, and copper alloys. 15-20 vol \% Formaldehyde is a typical inhibitor.

Useful on U, Pu, and their oxides in stainless steel and Inconel systerns. Has been used very effedively in conjunction with potassium permanganate. Extremely corrosive to carbon steel, 5-10 vol \%. Often inhibited with diethylthiourea.

Fluid maintained under a nitrogen blanket. 5 mils/yr corrosion rates for carbon and stainless steel. Proprietory product of Dow Chemical Company.
Surface structure was characterized to determine its effect on the DF. $0.2 \mathrm{M}$. 
TABLE A.1. (Contd)

\begin{tabular}{|c|c|c|c|c|c|}
\hline Application & Reagent/Concentration/Process & $\mathrm{DF} / \mathrm{r}_{1}^{\prime *}$ & Reference & Condition & Comments \\
\hline \multirow[t]{12}{*}{$\begin{array}{l}\text { Stainless S10.6) } \\
\text { (Contdi }\end{array}$} & 98. Oxalic acid (OX) & $80-90 \%$ & $\begin{array}{l}\text { Meservey 1970 } \\
\text { and Carlson, } 1970\end{array}$ & $\begin{array}{l}2 \mathrm{hr} \text { at } 90^{\circ} \mathrm{C} . \\
\text { pH } 3.6\end{array}$ & $\begin{array}{l}0.0005 \mathrm{M} \text {. Removes rust from iron, reacts with } \\
\text { stainless steel to form insoluble ferrous } \\
\text { oxalate. }\end{array}$ \\
\hline & 99. Oxalic peroxide (OPP! & 20 & $\begin{array}{l}\text { Meservey } 1970 \\
\text { Ayres } 1970\end{array}$ & $80^{\circ} \mathrm{C}, 1 \mathrm{hr}, \mathrm{pH} 4.5$ & $\begin{array}{l}\text { Mixture of } 0.025 \mathrm{M} \text { oxalic acid and } 0.5 \mathrm{M} \text { hydro- } \\
\text { gen peroxide. Principally used to clean oxides } \\
\text { of } \mathrm{U} \text { and } \mathrm{Pu} \text {. Frequently also includes } 0.25 \mathrm{M} \\
\mathrm{Na}_{2} \mathrm{C}_{2} \mathrm{O}_{4}, 0.006 \mathrm{M} \text { per acetic acid and } 0.007 \mathrm{M} \\
\text { oxine. }\end{array}$ \\
\hline & 100. Sulfamic acid $\left(\mathrm{NH}_{2} \mathrm{SO}, \mathrm{H}\right)$ !Su!! & 3 & Ayres 1970 & $45-80^{\circ} \mathrm{C}, 1.4 \mathrm{hr}$ & $\begin{array}{l}\text { Most useful of carbon steel. Not as prone to } \\
\text { redeposition as } \mathrm{H}_{3} \mathrm{PO}_{4} \text {. }\end{array}$ \\
\hline & 101. Sulfuric acid $\left(\mathrm{H}_{2} \mathrm{SO}_{4}\right\}$ & 2 & Carlson 1970 & $70^{\circ} \mathrm{C}, 1 \mathrm{hr}$ & $\begin{array}{l}\text { Used for localized contamination free from } \\
\text { calcium. Highly corrosive to base metals. } \\
\text { 5-10 vol \%. }\end{array}$ \\
\hline & 102. $\mathrm{NaOH} / \mathrm{KOH} / \mathrm{Na}_{3} \mathrm{O}_{2}$ & $95-99 \%$ & $\begin{array}{l}\text { Dippel, Hentschel, } \\
\text { and Kunze } 1976 \\
\text { KFK-2375 }\end{array}$ & $280^{\circ} \mathrm{C}, 45-60 \mathrm{~min}$ & $\begin{array}{l}\text { No concentrations or proportions provided } \\
\text { for entries } 102-106 \text {. }\end{array}$ \\
\hline & 103. $\mathrm{NaOH} / \mathrm{KOH} / \mathrm{Na}_{2} \mathrm{O}_{2} / \mathrm{Na}_{2} \mathrm{CO}_{3}$ & $93-97 \%$ & $\begin{array}{l}\text { Dippel. Hentschel, } \\
\text { and Kunze } 1976 \\
\text { KFK-2375 }\end{array}$ & $280^{\circ} \mathrm{C}, 15-45 \mathrm{~min}$ & \\
\hline & 104. $\mathrm{NH}_{4} \mathrm{H}_{1}, \mathrm{PO}_{4}$ & $97-99 \%$ & $\begin{array}{l}\text { Dippel, Hentscheli, } \\
\text { and Kunze } 1976 \\
\text { KFK-2375 }\end{array}$ & $220^{\circ} \mathrm{C}, 15 \mathrm{~min}$ & $\begin{array}{l}\text { Some salt melts limited by their corrosive } \\
\text { properties; hot spraying; good waste volume } \\
\text { reduction. }\end{array}$ \\
\hline & 105. $\mathrm{KH}_{2} \mathrm{PO}_{4}$ & $97-99 \%$ & $\begin{array}{l}\text { Dippel, Hentschel, } \\
\text { and Kunze } 1976 \\
\text { KFK-2375 }\end{array}$ & $280^{\circ} \mathrm{C}, 45 \mathrm{~min}$ & \\
\hline & 106. $\mathrm{NH}_{4} \mathrm{H}_{2} \mathrm{PO}_{4} / \mathrm{KH}_{4} \mathrm{PO}_{4}$ & $98 \%$ & $\begin{array}{l}\text { Dippel, Hentschel, } \\
\text { and Kun ze } 1976 \\
\text { KFK-2375 }\end{array}$ & $280^{\circ} \mathrm{C}, 45-60 \mathrm{~min}$ & \\
\hline & $\begin{array}{l}\text { 107. a) AP b) cilsox } \\
\text { 108. 5-20\% oxalic acid }+0.1 \% \text { EDTA }\end{array}$ & $6-25$ & $\begin{array}{l}\text { Remark and Miller } 1979 \\
\text { RDTPL-79-35 }\end{array}$ & $\begin{array}{l}180^{\circ} \mathrm{F} \\
180^{\circ} \mathrm{F}\end{array}$ & \\
\hline & $\begin{array}{l}\text { 110. } A C+E D T A \\
\text { 111. a) } A P \text { b) } A C+\text { ammonium oxalate }\end{array}$ & $\begin{array}{l}4-10 \\
2-56 \\
12-350\end{array}$ & $\begin{array}{l}\text { Remark and Miller } 1979 \\
\text { RDTPL-79-35 }\end{array}$ & & $\begin{array}{l}\text { Prevents copper redeposition, cation } \\
\text { exchange on waste. Proprietary product of } \\
\text { Nuclear Technology Corporation. } \\
\text { AC at } 4 \% ; \text { EDTA at } 3 \% \text {. } \\
\text { AP: } 10 \% \mathrm{NaOH}+3 \%, \mathrm{KMnO}_{4} \text { : AC al } 4 \% ; \\
\text { ammonium oxalate at } 3-5 \% \text {. }\end{array}$ \\
\hline & 112. NS-1 & $2-10$ & $\begin{array}{l}\text { Remark and Miller } 1979 \\
\text { RDTPL-79-35 }\end{array}$ & & $\begin{array}{l}\text { Solidify waste. Proprietary product of Dow } \\
\text { Chemical Coompany. }\end{array}$ \\
\hline
\end{tabular}


TABLE A.1. (Contd)

Application

Stainless Stcel (Contd)

占
Reagent/Concentration/Process

by $\mathrm{H}_{2} \mathrm{C}_{2} \mathrm{O}_{4} 25 \mathrm{~g} / 1+\left(\mathrm{NH}_{4}\right)_{2} \mathrm{HC}_{6} \mathrm{H}_{2} \mathrm{O}, 50 \mathrm{~g} / 1+17-36$

$\mathrm{Fe},\left(\mathrm{SO}_{4}\right)_{3} 2 \mathrm{~g} /$

+ diethylthiourea $1 \mathrm{~g} / \mathrm{I}$

114. $\mathrm{HNO}_{3}$ and $\mathrm{NaOH}$

115. $\mathrm{NaOH} / \mathrm{KMnO}_{4}, \mathrm{HNO}_{1}$, and EDTA

116. NS-1

117. APACE: recirculate AP, follow with a water flush, then recirculate inhibited $A C$. follow with a water flush

118. a) Recirculate with AP followed by water b) recirculate with a sodium bisulfate followed by water

a) Soak in $\mathrm{AP}$ b) pickle in $\mathrm{HCl}$ or $\mathrm{H}_{2} \mathrm{SO}_{4}$ or other monoxidizing acid

119. AP+3-10\%, organic acids and/or chelant and/or inhibitor

Paint

120. Water flush followed by $0.4 \mathrm{MH}_{2} \mathrm{C}_{2} \mathrm{O}_{4}, 20$ O. $\left.5 \mathrm{M} \mathrm{NaF}_{3}\right) .3 \mathrm{MH}_{2} \mathrm{O}_{2}$

Plastics

121. Use same procedures as for glass and stainless steel

Polyethylene

122. $2-10 \%$ polyvinyl alcohol in water $+1 \%$ EDTA $+15-20 \%$ ethyl alcohol

$+0.02 \%$ sodium carbonate
$\mathrm{DF} / \% *$

Reference

Weed 1968

BNWL-711

3-10

Hayashi et al.

paper 13

Hayashi et al.

paper 13

$85-99 \%$

Condition Comments

Van Nicda, AN5 Trans., June 1978

Ayres et al. 1962

HW-71259

Ayres et al. 1962 HW-71259

Posselt and Anderson

1967

Literature Review of

Chem. Decom. Processes

for Water Cooled Nuclea

Reactors NP-1033

Goldherg, Testing

1.E.C. Prod Res Dev

10 min

17 (1) $25-27$ (1978)

Christensen 1959

LAMS-2319

$70-97 \%$
25 or $\mathrm{B0}^{\circ} \mathrm{C}$

$80-105^{\circ} \mathrm{C}$

Provides comparison of corrosion data fo Haynes 25, 304, and 316 \$5, 17-4 pH SS, 440 SS. A 212 carbon steel, and others

Acid evaporator in reprocessing plant. $\mathrm{NaOH}$ was more effective than $\mathrm{HNO}_{3}$ in $\mathrm{Ru}_{\text {removal. }}$

Followed the $\mathrm{HNO}_{3}$ and $\mathrm{NaOH}$ steps of $\$ 113$.

$>100^{\circ} \mathrm{C}, 100-200 \mathrm{hr}$ Low surface tension fluid leaks through bydrostatically $\{1.5 \times$ operating pressure $\}$ threaded joints. Proprietary produrt of Dow Chemical Company.

No carbon steel in system; if rupture debris and fission products are present, the APACE procedure should be preceded by recirculation with $10 \mathrm{vol} / \% \mathrm{HNO}_{3}$. Phenylthiourea and acridine appear to be good inhibitors. AP: $3 \%, \mathrm{KMnO}_{4}+10 \% \mathrm{NaOH}_{\text {; }}$ AC: $4 \%$.

If fission products and rupture debris are present, precede this process by recirculation with a solution containing sodium carbonate, sodium bicarbonate and hydrogen peroxide. Sodium bisulfate at $2 \%$ by volume.

Cited for descaling. Acid al 3-5\% by volume.

Acids can include ciltic or glycolic acid. Chelants can include EDTA or its homologues. Inhibitors can include formaldehyde or diethylthiourea.

Plate glass, cpoxy, and epoxy phenolics generally give DF of 20 . Procedure was developed at ORN1 as coatings test procedure.

Apply by spray or brush. 
TABLE A.1. (Contd)

\begin{tabular}{|c|c|c|c|c|c|}
\hline Application & Reagenl/Concentration/Proces5 & DF $/ \mathrm{K}^{*}$ & Rolerence & Condition & Comments \\
\hline Porcelain & $\begin{array}{l}\text { 123. a) Rinse b) boil in saturated ammo- } \\
\text { nium carhonate for } 30 \text { min c) soak in } 5 \% \text { \% } \\
\text { ammonium biflouride for } 30 \mathrm{~min}\end{array}$ & & $\begin{array}{l}\text { Christensen } 1959 \\
\text { I.AMS-2319 }\end{array}$ & & Efficiency increases with temperature. \\
\hline \multirow[t]{2}{*}{ PVC } & $\begin{array}{l}\text { 124. Amino acetates or polyphosphates } \\
\text { plus a surfactant }\end{array}$ & & $\begin{array}{l}\text { KFK } 2500 \\
\text { Halbjahr } 1977\end{array}$ & $\begin{array}{l}\text { L'p to } 200^{\circ} \mathrm{C} \\
\text { usually } \\
60^{\circ} \mathrm{C}, 10 \mathrm{~min}\end{array}$ & Comparable to citric acid-based solutions. \\
\hline & $\begin{array}{l}\text { 125. } 2-10 \% \text { polyvinyl alcohol in water } \\
+1 \% \text { FDTA }+15-20 \% \text { ethyl alcohol } \\
+0.02 \% \text { sodium carbonate }\end{array}$ & $70-97 \%$ & Dippel 1976 & & Apply by brush or spray. \\
\hline Refractory & $\begin{array}{l}\text { 126. Anhydrous } \mathrm{H}_{2} \mathrm{SO}_{4}, \mathrm{H}_{3} \mathrm{PO}_{4} \\
\text { or } \mathrm{HNO}_{3}(100 \%)\end{array}$ & & $\begin{array}{l}\text { Ayres } 1971 \\
\text { BNWL-B-90 }\end{array}$ & & \\
\hline Soil & $\begin{array}{l}\text { 127. Wet screening with solutions of } \\
\text { oxalic acid and sodium hexameta- } \\
\text { phosphate }\end{array}$ & $180 \%$ & $\begin{array}{l}\text { Kochen et al. } 1979 \\
\text { RFP-2803 }\end{array}$ & & $\begin{array}{l}\text { Plutonium and americium contamination. Soil } \\
\text { wetted with the acid/phosphate solution and } \\
\text { passed Ihrough a } 2.4-\mathrm{mm} \text { screen. }\end{array}$ \\
\hline Wood & $\begin{array}{l}\text { 128. } 2-10 \% \text { polyvinyl alcohol in water } \\
+1 \% \text { EDTA }+15-20 \% \text { ethyl alcohol } \\
+0.02 \% \text { sodium carbonate: brush or spray }\end{array}$ & $70-97 \%$ & Dippel 1976 & & \\
\hline \multirow[t]{5}{*}{ 7.ircaloy } & $\begin{array}{l}\text { 129. Buffered oxalic acid }+\mathrm{H}_{2} \mathrm{O}_{2} \\
+ \text { gluconic acid }\end{array}$ & & Divine 1973 & $280^{\circ} \mathrm{C}, 15-45 \mathrm{~min}$ & $20 \mathrm{mg} / d \mathrm{~m}^{2}-d$ corrosion. \\
\hline & $\begin{array}{l}130.0 .4 \mathrm{MH}_{2} \mathrm{C}_{2} \mathrm{O}_{4}+0.1 \mathrm{MHF}+0.0-1.0 \mathrm{M} \\
\mathrm{H}_{2} \mathrm{O}_{2}\end{array}$ & & $\begin{array}{l}\text { Ayres } 1971 \\
\text { BNWL-B-90 }\end{array}$ & $2-4 \mathrm{hr}$ at $95^{\circ} \mathrm{C}$ & \\
\hline & $\begin{array}{l}\text { 131. Ar-Hr followed by aqueous fluoride } \\
\text { solution }\end{array}$ & $10^{4}$ & $\begin{array}{l}\text { Platt 1975a, b } \\
\text { BNWL } 1936 \text { and } \\
\text { BNWL-1913 }\end{array}$ & $600^{\circ} \mathrm{C}$ lor $45 \mathrm{~min}$ & $\begin{array}{l}55 \mu \mathrm{m} \text { surface removal, sparging of the melt } \\
\text { with } \mathrm{HF} \text { increases corrosion by sixfold. }\end{array}$ \\
\hline & $\begin{array}{l}\text { 1.32. } 20 \mathrm{hr} \text { in } 8 \mathrm{M} \mathrm{HNO} \text { followed by } 4 \mathrm{hr} \\
\text { in } 8 \mathrm{M} \mathrm{HNO} \text { at } 99^{\circ} \mathrm{C} \text { and a water rinse. } \\
\text { Further leached with a } 0.4 \mathrm{M} \text { ammonium } \\
\text { oxalate, } 0.16 \mathrm{M} \text { ammonium citrate, } 0.1 \mathrm{M} \\
\text { arnmonium fluoride. } 0.3 \mathrm{M} \mathrm{H}_{2} \mathrm{O}_{2} \text { at } 95^{\circ} \mathrm{C} \\
\text { for a total of } 12 \mathrm{hr} \text { in five fresh } 30 \mathrm{ml} \\
\text { aliquols of solution }\end{array}$ & $\begin{array}{l}1060 \% \\
\text { alpha } \\
\text { removal }\end{array}$ & $\begin{array}{l}\text { Platl 1975a, h } \\
\text { BNWL-1936 and } \\
\text { BNWL-1913 }\end{array}$ & & \\
\hline & $\begin{array}{l}\text { 133. } 0.0017 \mathrm{M} \text { EDTA }+0.00119 \mathrm{M} \text { citric acid } \\
+0.00198 \mathrm{M} \text { oxalic acid }\end{array}$ & 2 & $\begin{array}{l}\text { Krat cer } 1979 \\
\text { UNI-1425 }\end{array}$ & $\begin{array}{l}100^{\circ} \mathrm{C}, 70 \mathrm{l} / \mathrm{min} \\
\text { flow, } \mathrm{pH} 4.8\end{array}$ & $\sim 2.7 \mathrm{mg} / \mathrm{dm}^{2}-\mathrm{d}$ corrosion $(0.4 \mu \mathrm{m} / \mathrm{d})$ \\
\hline
\end{tabular}


TABLE A.1. (Contd)

\begin{tabular}{|c|c|c|c|c|c|}
\hline Application & Reagent/Concentralion/Process & $\mathrm{DF} / \mathrm{K}$, & Reícrence: & Condition & Comments \\
\hline \multirow[t]{9}{*}{$\begin{array}{l}\text { Zircaloy } \\
\text { (Contd) }\end{array}$} & $\begin{array}{l}\text { 134. Molten salt bath of } 37 \% \mathrm{NaF}, 37 \% \mathrm{LiF} \text {, } \\
\text { and } 26 \% \mathrm{ZrF}\end{array}$ & & $\begin{array}{l}\text { Platt 1975a, b } \\
\text { BNWI.-1936 and } \\
\text { BNWL-1913 }\end{array}$ & $705^{\circ} \mathrm{C}$ & $25-50 \mu \mathrm{m} / \mathrm{hr}$ on $\mathrm{Zr}-4$ at $650^{\circ} \mathrm{C}$. with $\mathrm{HF}$ sparge. \\
\hline & $\begin{array}{l}\text { 135. HF-Ar followed by organic acid } \\
\text { stripping }\end{array}$ & & $\begin{array}{l}\text { Platt } 1977 \\
\text { BNWL-2245, section } 5\end{array}$ & $\mathrm{HF}-\mathrm{Ar}$ at $600^{\circ} \mathrm{C}$ & $75 \% \mathrm{HF}, 25 \%$ Ar. \\
\hline & 136. $\mathrm{NaF}-\mathrm{LiF}_{-} \mathrm{ZrF}_{4}$ fused salt & & $\begin{array}{l}\text { Platt } 7977 \\
\text { BNWL-2245, section } 5\end{array}$ & $\begin{array}{l}704^{\circ} \mathrm{C} \text { up to } \\
60 \mathrm{~min}\end{array}$ & $\begin{array}{l}\text { Typical mole percentages: } 38 \mathrm{NaF}-24 \\
\text { Lif-38 } \mathrm{ZrF}_{4}\end{array}$ \\
\hline & 137. Molten zinc chloride & & $\begin{array}{l}\text { Steindler et al. } 1975 \\
\text { ANL-8152 }\end{array}$ & $500^{\circ} \mathrm{C}$ for $1 \mathrm{hr}$ & $\mathrm{Zr}+2 \mathrm{ZnCl}_{2} \rightarrow \mathrm{ZrCl}_{4}+2 \mathrm{Zn}$ \\
\hline & $\begin{array}{l}\text { 138. Double leaching in } 8 \mathrm{M} \mathrm{HNO} \text {, fol. } \\
\text { lowed by leaching in an ammonium } \\
\text { oxalate-citrate-peroxide solution }\end{array}$ & $\begin{array}{l}56 \% \text { alpha } \\
\text { removal }\end{array}$ & $\begin{array}{l}\text { Platt } 1975 c \\
\text { BNWL-1952, Section } 2\end{array}$ & $\begin{array}{l}24-\text { hr lotal. } \\
\text { up to } 99^{\circ} \mathrm{C}\end{array}$ & \\
\hline & $\begin{array}{l}\text { 139. } 50 \% \mathrm{HNO}_{3}-\mathrm{HF} \text { etch }\{1 \mathrm{~min} \text { ) followed } \\
\text { by concentrated } \mathrm{HNO}_{3}\end{array}$ & $99^{\prime} \%$ & $\begin{array}{l}\text { Dillon et al. } 1976 \\
\text { IAEA-SM-207/69 }\end{array}$ & & \\
\hline & 140. $0.4 \mathrm{M}\left(\mathrm{NH}_{4}\right)_{2} \mathrm{C}_{2} \mathrm{O}_{4}+0.3 \mathrm{M} \mathrm{H}_{2} \mathrm{O}_{2}$ & & $\begin{array}{l}\text { Dillon et al. } 1976 \\
\text { IAEA-SM-207/69 }\end{array}$ & $\begin{array}{l}90^{\circ} \mathrm{C} \text { for two } \\
2 \text { hr periods }\end{array}$ & Solution developed by Meservey. \\
\hline & $\begin{array}{l}\text { 141. } \mathrm{HF} \text { gas followed by }\left(\mathrm{NH}_{4}\right)_{2} \mathrm{C}_{2} \mathrm{O}_{4} \text {. } \\
\left(\mathrm{NH}_{4}\right)_{2} \mathrm{H} \mathrm{C}_{6} \mathrm{H}_{4} \mathrm{O}_{2}, \mathrm{H}_{2} \mathrm{O}: \mathrm{NH}_{4} \mathrm{~F}\end{array}$ & $99.7 \%$ & $\begin{array}{l}\text { Dillon et al. } 1976 \\
\text { IAEA-SM-207/69 }\end{array}$ & $\begin{array}{l}\mathrm{HF}-30 \mathrm{~min} \text { at } 600^{\circ} \mathrm{C} \\
\text { aqueous- } 1.2 \mathrm{hr} \\
\text { a! } 85^{\circ} \mathrm{C}\end{array}$ & HF temperature range $550-620^{\circ} \mathrm{C}$. \\
\hline & 142. Ammoniated EDTA + citric acid & & $\begin{array}{l}\text { Hampton } 1979 \\
\text { GEFR-00449 }\end{array}$ & $\begin{array}{l}80^{\circ} \mathrm{C}, 0.4 \mathrm{gpm} \\
4.0 \mathrm{gpm}\end{array}$ & $\begin{array}{l}\text { Scale removal from prototypically fouled } \\
\text { steam generator tubes, } 100 \% \text { EDTA, } 2 \% \text { citric } \\
\text { acid, } 1 \% \text { hydrazine, } 0.1 \% \text {, radiac } 33 \text {. }\end{array}$ \\
\hline $2-1 / 4 \mathrm{CR}-1 \mathrm{MO}$ & 143. Caustic & & $\begin{array}{l}\text { Marsh and Perkins } \\
1978 \\
\text { AERE-R-9267 }\end{array}$ & Up to $185^{\circ} \mathrm{C}$ & $\begin{array}{l}0.5 \mu \mathrm{m} / \mathrm{hr} \text { in boiling } 70 \% \mathrm{NaOH}\left(185^{\circ} \mathrm{C}\right) \text {; } \\
\text { intent of article is corrosion resistance, oxy- } \\
\text { gen must be eliminated. }\end{array}$ \\
\hline \multirow[t]{2}{*}{$\begin{array}{l}\text { Grease and Oil } \\
\text { Removal }\end{array}$} & $\begin{array}{l}\text { 144. } 1 \text { wt } \% \text { Lissapol (non-ionic wetting } \\
\text { agent) }+1.2 \text { wt } \% \text { sodium carbonate }+2 \\
\text { wt } \% \text { sodium tripolyphosphate }+0.1 \text { wt } \% \\
\text { sodium carbonymethylcellulose } \\
+0.5 w+\% \text { EDTA }\end{array}$ & & $\begin{array}{l}\text { Ayres } 1971 \\
\text { BNiWL-8-90 }\end{array}$ & pH 9.5 & $1 \%$ solution. Used as a detergent. \\
\hline & $\begin{array}{l}\text { 145. } 1.5 \text { wt'\% Comprox (anionic wetting } \\
\text { agent) }+2.5 \text { wt } \% \text { sodium sulfate }+0.6 \text { wt } \%\end{array}$ & & $\begin{array}{l}\text { Ayres } 1971 \\
\text { BNWL-8-90 }\end{array}$ & $\mathrm{pH} 3,70-80^{\circ} \mathrm{C}$ & $\begin{array}{l}\text { Detergent. but will attack metal. } \\
0.8 \% \text { solution. }\end{array}$ \\
\hline
\end{tabular}


IABLE A.2 Mechanical Decontamination Methods

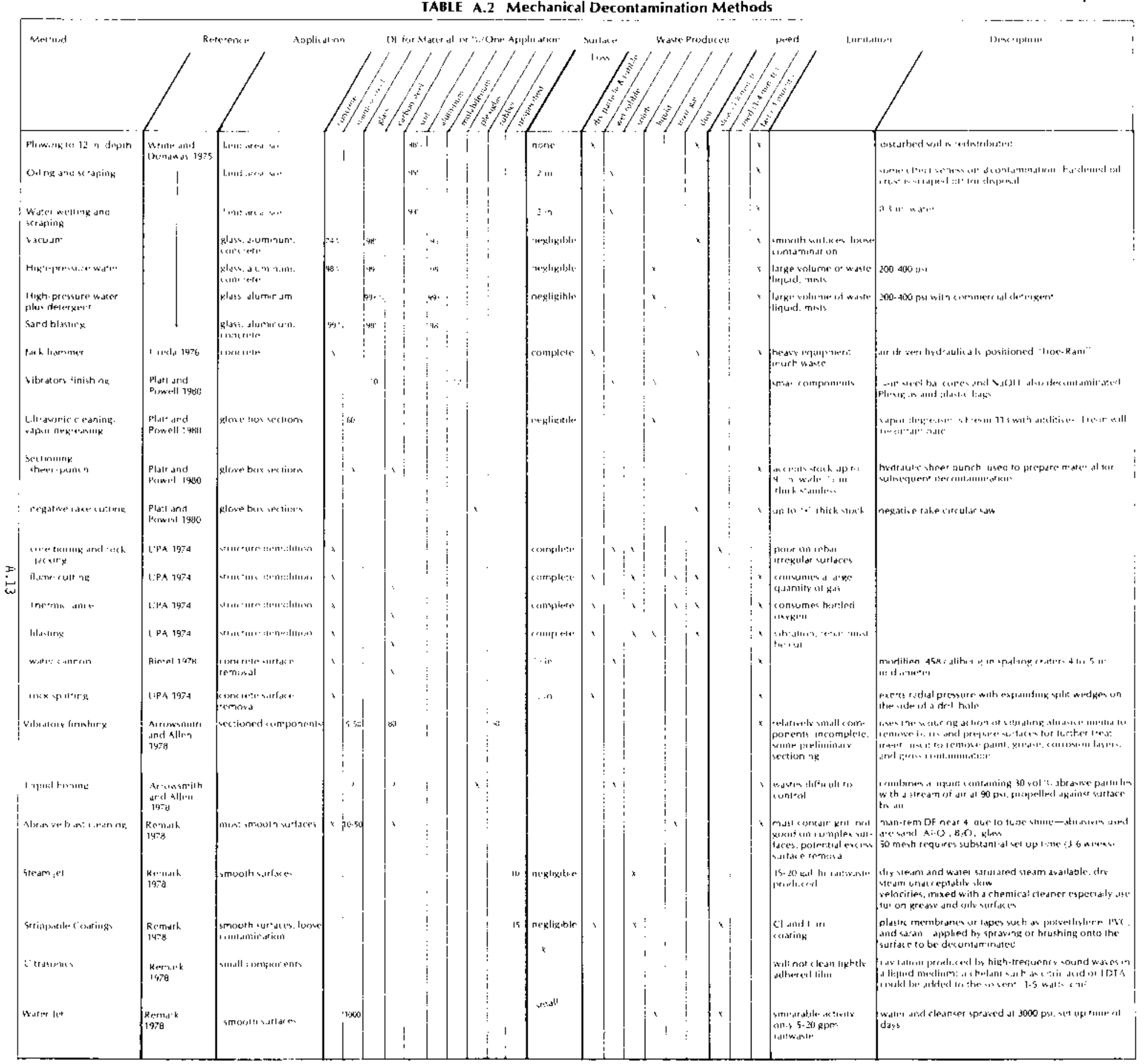




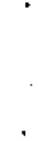


TABLE A.2 Mechanical Decontamination Methods (contd)

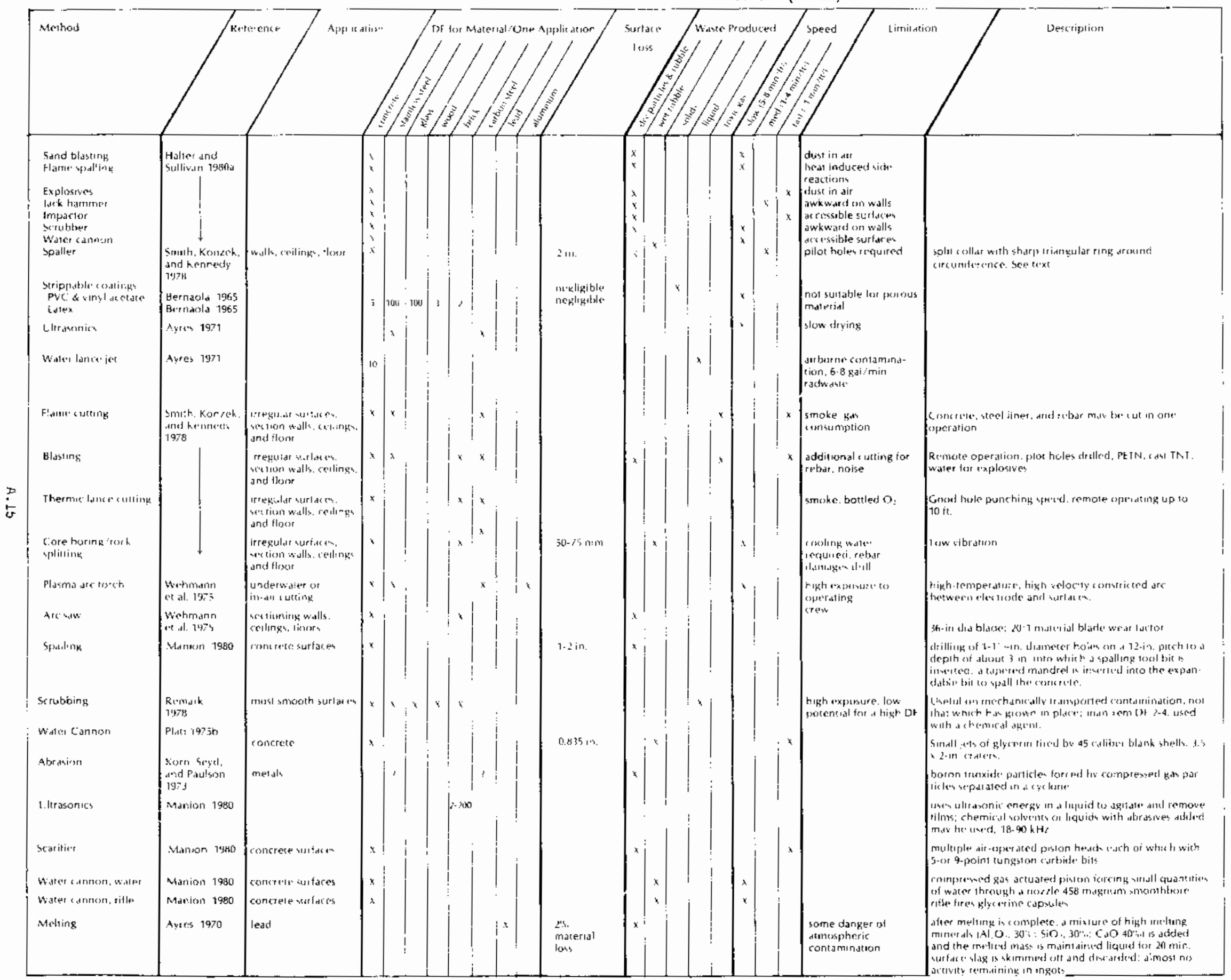


TABLE A.3 Electrochemical Decontamination Methods

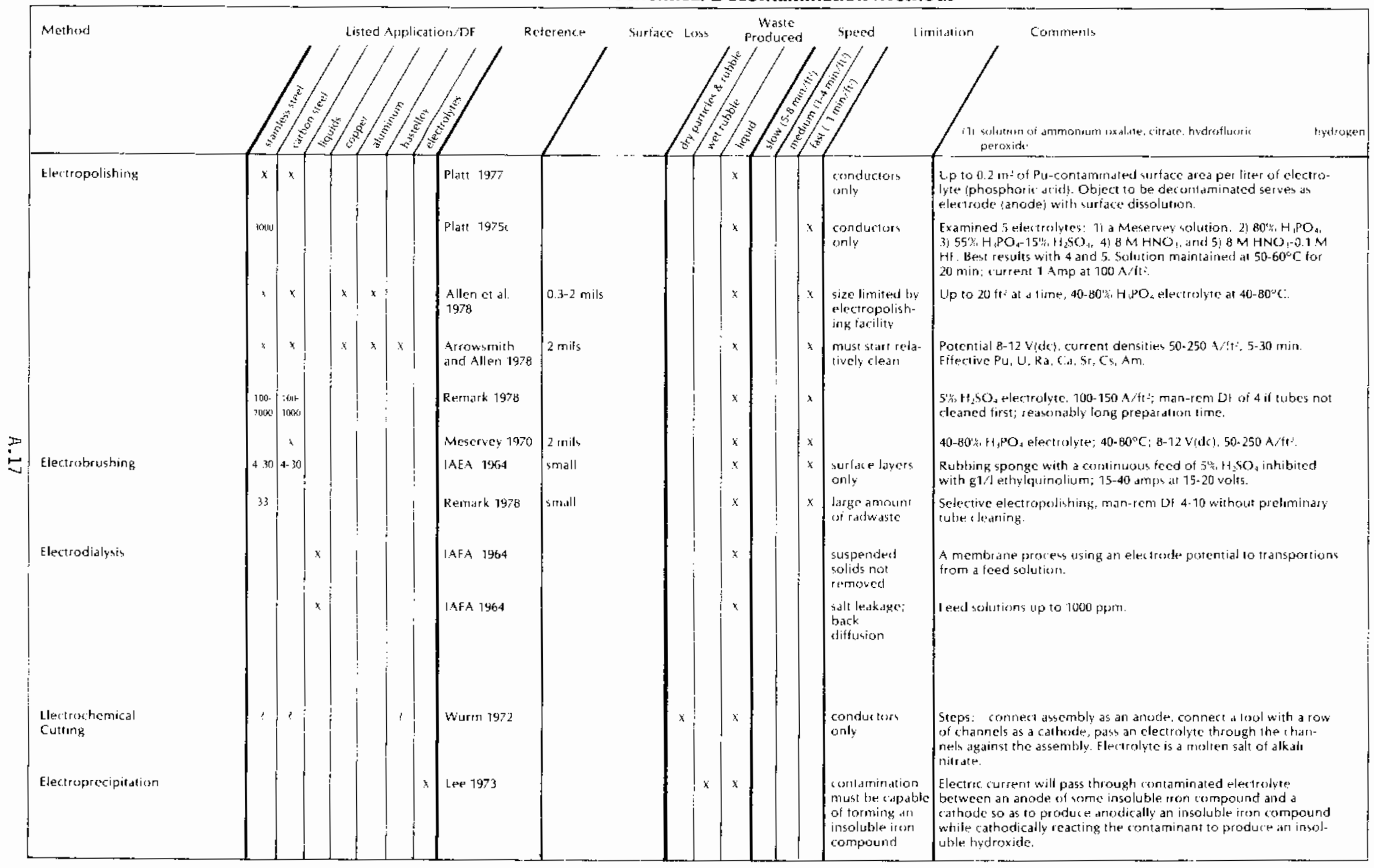


TABLE A.4. Radioactive Waste Decontamination

\begin{tabular}{|c|c|c|c|}
\hline Method & Reference & Application & Description \\
\hline 1. Adsorption & $\begin{array}{l}\text { Herald, Roberts, and } \\
\text { Williarns } 1978 \\
\text { MLM- } 2566\end{array}$ & Aqueous wastes & Adsorption by bone char or JRA-9038 at $\mathrm{pH} 3-10 ; \mathrm{DF} \approx 145$ for $U$. \\
\hline 2. Adsorption & $\begin{array}{l}\text { Wiley } 1976 \\
\text { DP- } 1408\end{array}$ & Waste supernates containing $\mathrm{Sr}, \mathrm{Pu}$ & $\begin{array}{l}\text { Pu adsorbed by Duolite ARC-339; } \mathrm{Sr} \text {, adsorbed by Chelex } 100 \text { or precipi- } \\
\text { tated as } \mathrm{Sr}_{3}\left(\mathrm{PO}_{4}\right)_{2} ; \mathrm{Sr} \mathrm{DF} \approx 300 ; \mathrm{Pu} \mathrm{DF} \approx 20 \text {. }\end{array}$ \\
\hline $\begin{array}{l}\text { 3. Adsorption, } \\
\text { Activated Carbon }\end{array}$ & Straub 1972 & Aqueous deactivation wastes & $\begin{array}{l}\text { Clarifier-contactor used for sedimentation of suspensions with activated } \\
\text { carbon; DFs } 90-99 \% \text {; volume concentration }+99 \%,\end{array}$ \\
\hline 4. Adsorption, Inorganic & $\begin{array}{l}\text { Rauzen and I rushkov } 1972 \\
\text { L:DC } 621.039 .7 ; 66.074 .7\end{array}$ & Acqueous deactivation wastes & $\begin{array}{l}\text { Deactivation by the use of partially sulferated bitumen in an otherwise } \\
\text { ion-exchange type process; DF of } 10-100 \text {. }\end{array}$ \\
\hline $\begin{array}{l}\text { 5. Adsorption, } \\
\text { Iron Zeolite }\end{array}$ & Verot 1968 & Aqueous deactivation wastes & $\begin{array}{l}\text { Deactivation by adjusting solution } \mathrm{pH} \text { to } 1-3 \text {, percolating it over finely } \\
\text { divided active iron at a temperature below } 70^{\circ} \mathrm{C} \text {, raising the } \mathrm{pH} \text { to a } \\
\text { value of } 7-10 \text {, and contacting the liquid with synthetic zeolites. }\end{array}$ \\
\hline $\begin{array}{l}\text { 6. Adsorption/ } \\
\text { Gas Scrubbing }\end{array}$ & $\begin{array}{l}\text { Deuber and Birke } 1978 \\
\text { KFK-2600 }\end{array}$ & lodine removal from stack gas & $\begin{array}{l}\text { Sorb with DSM II to remove }{ }^{131} \mathrm{I} \text { as } \mathrm{I} \text { 俄 } \mathrm{HIO} \text {; } \mathrm{DF} \approx 100 \text { at } 40^{\circ} \mathrm{C} \text { and } 50 \% \\
\text { relative humidity. }\end{array}$ \\
\hline 7. Coagulation & Malasek 1967 & Low-level waste water & $\begin{array}{l}\text { Sorption of }{ }^{32 p},{ }^{355} \text {, and }{ }^{131} \mid \text { on ionic precipitates, barium sulphate and } \\
\text { carbonate, hydrated oxide, of iron, aluminum, and zinc-aluminum. }\end{array}$ \\
\hline 8. Coagulation & $\begin{array}{l}\text { Kalandiya } 1973 \\
\text { L'DC } 653.632 ; 541.183 .1 \\
539.173 .8\end{array}$ & Aqueous wastes & $\begin{array}{l}\text { Use of calcium and iron phosphates at a } \mathrm{pH} \text { of } 9.5 \text { allows } 96 \% \text { removal of } \\
\mathrm{Sr} \text { and } 77 \% \text { of } U \text { fission products. }\end{array}$ \\
\hline 9. Coagulation & Kolychev and Sedov 1968 & Aqueous wastes & $\begin{array}{l}\text { Ferrous or aluminum sulphate used as coagulant - } \mathrm{pH} 8-10 ; 70-80 \% \\
\text { activity removal;sludge volume } 0.5 \% \text {, of initial volume. }\end{array}$ \\
\hline $\begin{array}{l}\text { 10. Coagulation-lon } \\
\text { Exchange }\end{array}$ & $\begin{array}{l}\text { Mercer and Ames } 1977 \\
\text { BNWL-2274 }\end{array}$ & Aclivated laundry waste & $\begin{array}{l}\text { Waste waler ireated with } \mathrm{Fe}^{+3}, \mathrm{Mg}^{+2} \text {, and } \mathrm{Ca}^{+2} \text { salts at } \mathrm{pH} 11 \text { lo coagu- } \\
\text { late suspended solids and scavenge radionuclides. Ion exchange } \\
\text { removes residual } \mathrm{Cs} \text { and } \mathrm{Sr} \text {. }\end{array}$ \\
\hline $\begin{array}{l}\text { 11. Condensation, Low } \\
\text { Temperature }\end{array}$ & $\begin{array}{l}\text { Kolychev et at. } 1968 \\
\text { LDC } 627.034 .75\end{array}$ & $\begin{array}{l}\text { Removal of } \mathrm{Kr}, \mathrm{Xe} \text {, and I } \\
\text { from gases }\end{array}$ & $\begin{array}{l}\text { Low-temperature condensation followed by extraction stripping with } \\
\text { organic reagents or filtration with fibered materials such as FP tissue or } \\
\text { glass fiber. }\end{array}$ \\
\hline 12. Electrodialysis & Kolychev and Sedov 1968 & Aqueous waste & $\begin{array}{l}\text { 1) desalination, 2| ion exchange, 3) electrodialysis to recover acid and } \\
\text { alkali from spent regeneration solution. }\end{array}$ \\
\hline 13. Electrodialysis & Kolychev and Sedov 1968 & Low-level aqueous waste solutions & $\begin{array}{l}\text { lons separated by forced diffusion through a semipermeable } \\
\text { membranc; power consumption } 1 \mathrm{kWh} / \mathrm{m}^{3} \text { of wastes. }\end{array}$ \\
\hline 14. Electrophoresis & Kolycher and Sedov 1968 & Low-level aqueous waste solutions & $\begin{array}{l}\text { lon separated by electromotively forced diffusion through an } \\
\text { clecirolyte. }\end{array}$ \\
\hline
\end{tabular}


TABLE A.4. (Contd)

Method

15. Evaporation

Kolychev and Sedov 1968

16. Evaporation

Malasek 1967

17. Evaporation

Kolychev and Sedov 1968

18. Evaporation/Filtration/Kolychevet al. 1968 Electrophoresis/Ion Exchange

19. Filtration UDC 627.034.75

20. Foam Flotation

IAEA 1964

IAEA 1964

21. Foam Flotation

22. Foam Separation

23. Foam Flotation

24. freezing and Thawing Followed by Settlement

and Filtration

25. Incineration

26. Ion Exchange

27. Ion Exchange

28. Ion Exchange

29. Natural and Mineral Sorbents

Forminykh et al. 1973 UDC 16.066.661.185

Malasek 1967

Lindsay, Michels, and Martinez RFP-1949

IAEA 1964

IAEA 1964

Malasek 1967

Malasek 1967
Application

Aqueous waste volume reduction

Remove radioisotopes from water and concentrate regeneration solutions

Aqueous wastes

Aqueous wastes from primary loops

Sludge removal

Cs, Sr, and rare earth calion removal from aqueous solutions

Bahr et al, 1976; KFK-2418

SAI $1978 \mathrm{Y} / \mathrm{OW} / \mathrm{TM}-36 / 22$

Waste wate

Combustible solids and organic liquids

Cation exchange Anion exchange

Low-level waste water

Natural waters
Description

Suitable for wasles having a) high total solids concentration, bi small volume with relatively high activity, c) need of high DF using standard evaporation technology, constrained by minimization of carryover.

DF of $10^{5}-10^{7}$ possible if no organics present; foaming sometimes a problem; filtering vapor will increase DF.

Useful when there is no foaming agent in waste and salı concentration is less than $1 \%$.

Four-step process using quartz and anthracite as filtering media, then cationite; steam from evaporation is decontaminated in a packed scrubber: sludges from evaporators are bound in concrete.

Pressure and rotating drum filters. A precoat of diatomeceous earth may be required.

Uses the concentration difference existing between surface layers and the bulk regiont of solutions containing surface active solutes.

Use of quaternary ammonium salts as foam formers and gelatin as a surlactant; $60-76 \mathrm{mg} / \mathrm{l}$ of surfactant; removes $90-90 \%$ of the clay.

Removal of $\mathrm{Sr}, \mathrm{C}_{3}$, and $\mathrm{Ce}_{2}$ using lauryl sulphonater, fatty acid salts, and some industrial foaming agents; volume reduction to 0.1-1.0\%

Commercially available foam in a 2 -in, thick layer on soil will stabilize contamination and provide a protective cover.

Completely freeze the sludge to concentrate the electrolytes around the colloidal particles, giving rise to coagulation. Filters rapidly after thawing.

$1000-12000^{\circ} \mathrm{C} 100: 1$ volume reduction; ashes fixed in concrete.

Hydrogen ion exchange for mixed isotopes.

Limited utility except for iodine, sulfur, and phosphorous.

1) ion exchange to remove hardness, 2! cation exchange, 3) anion exchange, $D F=1000$

Used as a second step in combination with chemical treatment or evaporation; Ca, Sr, Y, Zr, Ru, Cs, and Ce removed; resins not described.

Zeolitically iransferred pumice, rhyolite, hasaltic, and tephritic tuffs best for cesium; rhyodactic tuffs best for strontium. 
TABLE A.4. (Contd)

Method

30. Natural Sorbents

Coagulated in an Electric

Field

31. Ion Exchange

32. Ion Exchange

33. Ion Exchange

34. Ion Exchange

35. Ion Excharige

36. Leaching

37. Molecular Sieves/Gas Scrubbing

38. Osmosis, Reverse/

Ultra-filtration

39. Precipitation
Reterence:

Malasek 1967

Verot 1968

Wilding and Rhodes 1974 ICP- 1048

Lin 1973

ORNL-4792

Ryabchikov et al. 1974 CDC 621.039.73

Kolychev and Sedov 1968

Lagerwerlf and Kemper 1975

Deuber and Birke 1978

KFK-2600

Koenst and Roberts 1968

MLM-2448

IAEA 1964
Application

Waste water

Low-level waste water

Fuel storage basin water

Aqueous deactivation wastes

Aqueous effluents

\section{Aqueous wastes}

Contaminated soil

$\mathrm{Kr}$ and $\mathrm{Xe}$ removal from air

Low-level waste waler

Cesium removal from water

Sulfur and radium removal from water; strontium removal from water; rare earth removal; calcium removal; Cs and polyvalent cation removal

\section{Radionuclide mixes}

Electrolyte solutions
Description

Similar to previous natural sorbents except coagulation through aluminum clectrodes; $0.2 \%$ concentration of the suspension, current density $0.01 \mathrm{~A} / \mathrm{cm}^{2}$.

Adjust pHt to between 1 and 3, pass over finely divided active iron at less than $70^{\circ} \mathrm{C}$, raise $\mathrm{pH}$ to $8-10$, and contact solution with synthetic zeolites.

${ }^{13} \mathrm{C}$ S removed by zeolites (zeolon-900); $\mathrm{Sr}-90$ removed by organic cation resins (Amberlite-200)

Resin type: strong-acid cation and strong-base anion exchange resins of polystyrene matrix; mixed bed units most widely employed in sizes ranging from 2-8 ft in diameter to 3-6 ft in depth; feed 1-50 $\mathrm{gpm}$ of waste per square foot of cross-sectional area; temperature around $140^{\circ} \mathrm{F}$.

Pulsation sorption columns used in conjunction with ion exchange resins; DF around 12; 50-100 vibrations per minute; amplitude of 5-10 $\mathrm{mm}$; process about $1 \mathrm{~m}^{3 / \mathrm{hr}}$.

Usually a 2-stage process using $\mathrm{H}$-form strong-acid resin and $\mathrm{OH}$-form weak-base anion resins; will remove foaming agents.

Leach with $0.06 \mathrm{~N} \mathrm{CaCl}_{2}$ to remove $\mathrm{Sr}$

Acid-resistant molecular sieves, such as Norton Zeolen.

Contact waste solution with a semipermeable membrane; volume reduction of $200: 1 ; \mathrm{DF} \approx 10^{2}-10^{3}$.

Coprecipitation in the presence of $\mathrm{NiSO}_{4}$ or $\mathrm{CuSO}_{4}$ and $\mathrm{K}_{4} \mathrm{Fe}(\mathrm{CN})_{6} ; \mathrm{pH}$ of $7-10$, may require ferric hydroxide for flocculation.

Coprecipitation of barium-sulphate may require ferric hydroxide for flocculation. Addition of an inactive strontium salt in the presence of an excess of phosphate ions at high $\mathrm{pH}$. Flocculation wilh ferric or ferrous salts and regulation of $\mathrm{pH}$. Precipitate as calcium phosphate in a Ca-PO ratio of 1/1.6; $\mathrm{pH} 10-12$ or lime-soda treatment. Precipitate $\mathrm{C}_{5}$ with either copper or nickel ferrocyanide; remove polyvalent cations with tri-sodium phosphate and a ferric salt; $\mathrm{pH} 10$.

Flocculation with ferric salts followed by the calcium phosphate treatment.

Useful on electrolytes such as $\mathrm{HNO}_{3}, \mathrm{NaNO}_{3}$, and $\mathrm{NaOH}$; precipitate with acrylamide copolymers; centrafuge will remove particles up to 1 micron. 
TABLE A.4. (Contd)

\section{Method}

41. Precipitation

42. Precipitation/Foam

Contaction

43. Gas Scrubbing

44. Gas Scrubbing

45. Scrubbing of Soils

with Water
Reference

Bagretsov et al. 1970

UDC 621.039.714

King, Shimozato,

and Holmes 1968

ORNL-3803

Groenier 1973

ORNL-TM-4125

Mailen and Horner 1976

Horton and Albenesius 1976
Application

Aqueous deacrivation wastes

Low-level waste water

lodine removal from air

Air streams

Soils: volume reduction for

Pu contamination
Description

Nickel ferrocyanide at $100 \mathrm{mg} /$ liter removes $\mathrm{Cs}$ to $+99 \% ; \mathrm{pH}$ ranges 8-11, filter precipitate and evaporate.

Two-step process: 1) precipitate $\mathrm{Ca}, \mathrm{Mg}$, and radionuclides in a sludgeblanket clarification step using grundite clay 2) countercurrent foam contacting, Sr DF $\approx 1050$.

Coumtercurrent contacting with $\mathrm{HNO}_{3}$ removes iodine in the form methyl iodine; $70 \% \mathrm{HNO}_{1}$ at $80^{\circ} \mathrm{C} ; \mathrm{Di} \approx 10^{4}$.

Molecular iodine and methyl iodide removed by electrolytic scrubbing using a solution of cobalt in dilute nitric acid; $D F \sim 100$.

Water scrubbing separated out a clay-silt fraction containing $\sim 95 \%$ of the

Pu but comprising only one-third of the total soil. 
APPENDIX B

GLOSSARY OF TERMS 


\section{APPENDIX B}

\section{GLOSSARY OF TERMS}

Definitions of words directly related to decontamination and decommissioning (D\&D) are given in this section. This listing is an adaption of that given by G. J. Konzek and C. R. Sample. (a)

Abnormal Environmental Occurrence: An event that 1) results in noncompliance with, or is in violation of, an Environmental Technical Specification or 2) results in uncontrolled or unplanned releases of chemical, radioactive, or other discharges from the plant in excess of federal, state, or local regulations.

Activity: Sometimes used for the term "radioactivity," particularly when referring to an amount of radioactivity; i.e., the number of nuclear transformations occurring in a given quantity of material per unit of time.

Airborne Radioactive: Radioactive particulates, mists, fumes, and/or gases in the air.

ALARA: A philosophy to maintain exposure to radiation As Low $\underline{\text { AS }}$ is Reasonably Achievable.

Alpha-Bearing Waste: Waste containing alpha-emitting radionuclides, usually actinides.

Alpha Decay: Radioactive decay in which an alpha particle is emitted. This transformation lowers the atomic number of the nucleus by two and its mass number by four.

Alpha Particle: A positively charged particle emitted by certain radioactive materials. It is made up of two neutrons and two protons; hence, it is

(a) Konzek, G. J., and C. R. Sample. 1978. Decommissioning of Nuclear Facilities - An Annotated Bibliography. NUREG/CR-0130, Pacific Northwest Laboratory, Richland, Washington. 
identical with the nucleus of a helium atom. It is the least penetrating of the three common types of radiation (alpha, beta, and gamma) emitted by radioactive material.

Alpha Emitter: A radionuclide that undergoes transformation by emission of alpha particles.

Background: That level of radioactivity from sources existing without the presence of a nuclear plant, adjusted for any change occurring during the lifetime of a nuclear facility such as might result from atmospheric weapons testing.

Barriers: Engineered or natural obstacles that delay or prevent radionuclide migration from the repository.

Beta Decay: Radioactive decay in which a beta particle is emitted or in which an orbital electron capture occurs.

Beta Particle: An electron of either positive or negative charge that has been emitted by an atomic nucleus in a nuclear transformation.

Biological Shield: A mass of absorbing material placed around a reactor or radioactive source to reduce the radiation to a level that is safe for human beings.

Boiling Water Reactor (BWR): A reactor in which water, which is used as both coolant and moderator, is allowed to boil in the core. The resulting steam can be separated from the water and fed either directiy or through a heat exchanger to a turbine-generator.

Buffer Zone: Zone around the disposal areas of a repository established to insure a safe distance from surrounding strata and for human activities (excavating, etc.).

Chemical Limits: Maximum concentrations or quantities imposed upon chemical releases in gaseous or liquid effluents discharged from a facility and consistent with known air or water quality standards. 
Concentrated Reagents: Decontamination solutions containing more than about 2000 ppm of reagent.

Contamination: Radioactive material or materials that has been deposited on the surfaces of structures or equipment or that has been mixed with another material.

Continuing Care Period: The surveillance and maintenance phase of Safe Storage, with the facility secured against intrusion.

Curie ( $\mathrm{C} i)$ : The special unit of radioactivity: 1 curie $=3.7 \times 10^{10}$ nuclear transformations per second. Several fractions of the curie are in common usage:

- millicurie - One-thousandth of a curie $(\mathrm{mC} i)=3.7 \times 10^{7}$ disintegrations per second (dps).

- microcurie - One-millionth of a curie $(\mu \mathrm{Ci})=3.7 \times 10^{4} \mathrm{dps}$.

- nanocurie - One-billionth of a curie (nci) $=37 \mathrm{dps}$.

- picocurie - One-millionth of a microcurie $(\mathrm{pC} i)$. Replaces the term $\mu \mu \mathrm{C}=0.037 \mathrm{dps}$.

Decay, Radioactive: A spontaneous nuclear transformation in which a particle, gamma radiation, or $x$ radiation is emitted following orbital electron capture or spontaneous fission of the nucieus.

Decomissioning: Preparation of the nuclear facilities for retirement from active service accompanied by the execution of a program to reduce or stabilize radioactive contamination to reduce the potential health and safety impacts on the pub1ic.

Decontamination: Those activities employed to reduce the levels of radioactive contamination in or on structures and equipment.

Decontamination Agents: Those chemical materials used to effect decontamination. 
Decontamination Factor (DF): Defined as the original amount of radionuclide $\left(A_{0}\right)$ divided by the final amount $\left(A_{f}\right)$. In some cases, decontamination effectiveness is reported in terms of percent of contamination removed

$$
100\left[\frac{\left(A_{0}-A_{f}\right)}{A_{0}}\right]=100\left(1-\frac{1}{D F}\right)
$$

Dilute Reagents: Decontamination solutions generally containing less than 2000-ppm reagent.

De minimus Level: That level of contamination below which regulatory control is not required.

0isintegration, Nuclear: Spontaneous nuclear transformation (radioactivity) characterized by the emission of energy and/or mass from the nucleus. The process is characterized by a definite half-life.

Disintegration Rate: The rate at which disintegrations occur, characterized in units of time, i.e., disintegrations per minute $(d p m)$, etc.

Dismantlement: Those actions required to remove all radioactive or contaminated material from the facility, thus permitting unrestricted release of the property.

Dispersion: A process of mixing one material within a larger quantity of another. For example, the mixing of material released to the atmosphere with air causes a reduction in concentration with distance from the source.

Disposal: The disposition of materials with the intent that the materials will not enter man's environment in sufficient amounts to cause a health hazard.

Dose, Absorbed: The mean energy imparted to matter by ionizing radiation per unit mass of irradiated material at the place of interest. The unit of absorbed dose is the rad. One rad equals 0.01 joules/kilogram in any medium (100 ergs per gram). 
Dose, Equivalent: Expresses the amount of effective radiation in man, expressed in rems, when modifying factors have been considered. The product of absorbed dose multiplied by a quality factor multiplied by a distribution factor.

Dose, Occupationa 1: The exposure of an individual to radiation imposed by his employment other than natural background and medical exposures.

Dose, Radiation: As comnonly used, it is the quantity of radiation absorbed in a unit mass of a medium, frequently a human organ.

Dose Rate: The radiation dose delivered per unit time and measured, for instance, in rems per hour.

Entombment: The encasement of radioactive materials in concrete or other structural material sufficiently strong and structurally long-lived to assure retention of the radioactivity until it has decayed to levels that permit unconditional release of the site.

Exposure: A measure of the ionization produced in air by $x$ or gamma radiation. It is the sum of the electrical charges on all ions of one sign produced in air when all electrons liberated by photons in a volume element of air are completely stopped in air, divided by the mass of the air in the volume element. The special unit of exposure is the roentgen.

Exposure Decontamination Factor: Defined as original exposure rate divided by the final exposure rate. This can differ from DF for at least two reasons. First, DF is measured on the basis of the item cleaned and there may be other uncleaned areas nearby that contribute to the exposure rate. Consequently, a DF of 1000 might be achieved, but due to "shine" the exposure DF might be only 4. Second, the source might be contaminated with both beta and garma emitters. Initially, the high gamma field would hide the beta field. After a successful decontamination that removed essentially all of the garma emitters, one might find a high exposure due to the remaining beta emitters.

Facility: The physical complex of buildings and equipment within a site. 
Fission: The splitting of a heavy nucleus into two lighter nuclei (nuclides of lighter elements), accompanied by the release of a relatively large amount of energy and generaliy one or more neutrons. Fission can occur spontaneously, but usually it is caused by nuclear absorption of gamma rays, neutrons, or other particles.

Fission Products: The lighter nuclides (fission fragments) formed by the fission of heavy elements. It also refers to the nuclides formed by the fission fragments radioactive decay.

Fuel Assemb 1y: A grouping of fuel elements that supply the nuclear heat in a nuclear reactor. A fuel element is the smallest structurally discrete part of a reactor core or fuel assembly that has nuclear fuel as its principal constituent.

Ganma Rays: High-energy, short-wavelength, electromagnetic radiation. Gamma radiation frequently accompanies alpha and beta emissions and always accompanies fission. Gamma rays are very penetrating and are best stopped or shielded against by dense materials such as lead or depeleted uranium. The rays are similar to $x$-rays but are usually more energetic and are nuclear in origin, i.e., they originate from within the nucleus of the atom.

Greenhouse: A temporary structure, frequently constructed of wood and plastic, used to provide a confinement barrier between a radioactive work area and the environs.

Half-Life, Biological: The time required for a biological system, such as a man or animal, to el iminate, by natural processes, half the amount of a substance (such as a radioactive material) that has entered it.

Half-Life, Effective: The time required for a radionuclide contained in a biological system such as a man or animal to reduce its radioactivity by half as a combined result of radioactive decay and biological elimination.

Half-Life, Radioactive: The time in which half the atoms of a particular radioactive substance disintegrate to another nuclear form. Each radionuclide has a unique half-life, and measured half-lives vary from millionths of a second to billions of years. 
High-Level Liquid Radioactive Waste: Wastes resulting from the operation of the first cycle solvent extraction system, or equivalent, in a facility for reprocessing irradiated reactor fuels (10 CFR 50, App. F.2). It also applies generally to self-heating radioactive wastes of other origins, where the rate of heat evolution becomes of concern in waste disposal.

Hot Spots: Areas of radioactive contamination of a concentration higher than average.

Immobilization: Treatment and/or emplacement of material (e.g., radioactive contamination) so as to impede its movement.

Interim Care Period: A period of time starting after the decommissioning activities cease and wherein periodic surveillance and maintenance takes place. The duration of time can vary from a few years to more than 100 years; also called the continuing care period.

Interim Storage: Storage operations for which 1) monitoring and human control are provided and 2) subsequent action in which final disposition is expected. Concepts for interim storage include bulk or compartmented storage of solid, liquid, and gaseous wastes.

Ion Exchange: A chemical process involving the absorption or desorption of various chemical ions in a solution onto a solid material, usually a plastic or resin. The process is used to separate and purify chemicals, such as fission products or "hardness" in water (i.e., water softening).

Isotope: One of two or more atoms with the same atomic numbers (the same chemical element) but with different atomic weights. Isotopes usually have very nearly the same chemical properties but somewhat different physical properties.

Jetting: A technique for pumping a liquid or a gas by use of high-pressure air, steam, or water through specially designed nozzles. "Jet" is short for ejector.

License: Formal document issued by the Regulatory Body for major stages in the development of a nuclear facility defined by regulations permitting the holder (implementing organization) to perform specified activities. 
Liquid Radioactive Waste: Solutions, suspensions, and mobile sludges contaminated with radioactive materials.

Long-Lived Nuclides: Long-lived radionuclides are those for which decay does not provide an adequate method of control.

Low-Level Waste (LLW): Wastes containing types and concentrations of radioactivity such that no shielding or relatively little shielding is required to minimize personnel exposure.

Management (Waste): The planning, execution, and surveillance of essential functions related to control of radioactive waste, including treatment, solidification, interim or long-term storage, transportation, and disposal.

Man-Rem: A measure of population dose calculated by suming the dose equivalent in rem received by each person in the population. For occupational workers it is also used as the absorbed dose of one rem by one person with no rate of exposure inferred.

Megawatt-Day per Metric Ton: A unit for expressing the burnup of fue 1 in a reactor; specificaliy, the number of megawatt-days of heat output per metric ton of fuel in reactor.

Millirad: A unit of absorbed dose equal to one thousandth of a rad (see Dose, Absorbed).

Milliroentgen: A submultiple of the roentgen equal to one-thousandth of a roentgen (see Roentgen).

Monitoring: Taking measurements or observations for recognizing adequacy, significant changes in, conditions, or performance of a facility.

Nuc lear System: Generally includes those systems most closely associated with the reactor vessel that are designed to contain or be in communication with the water coming from or going to the reactor core. The nuclear system includes the following:

- reactor

- reactor assembly and internais

- reactor core

- neutron monitoring system 
- reactor coolant recirculation system

- control rod drive system

- residual heat removal system

- chemical volume and control system (PWR)

- emergency core cooling (ECC) systems.

Nuclide: A species of atom characterized by its mass number, atomic number, and nuclear energy state, provided that the mean life in that state is long enough to be observable.

Offsite: Beyond the boundary line marking the limits of plant property. Onsite: Within the boundary line marking the limits of plant property.

Pathway: A route and sequence of processes by which radioactive material may move to man's environment and to man.

Power Reactor: A generator of heat through controlled nuclear fission. Such heat energy, in turn, is used to generate power.

Pressurized Water Reactor (PWR): A power reactor in which heat is transferred from the core to a heat exchanger by water kept under high pressure to achieve high temperature without boiling in the primary system. Steam is generated in a secondary circuit.

Primary Wastes: Wastes that are generated as part of a primary operation. Secondary wastes are generated from a supporting operation, such as waste treatment.

Process Cells: Heavily shielded rooms housing radioactive processing systems.

Process Equipment: The functional equipment items or systems associated directly with the operation of a chemical or mechanical operation.

Protective Clothing: Special clothing worn by a person in a radioactively contaminated area to prevent contamination of his body or personal clothing. Protective Survey: An evaluation of the radiation and its hazards incidental to the production, use, or existence of radioactive materials. It normally 
includes a physical survey of the arrangement and use of equipment and measurements of the radiation dose rates under expected conditions of use; also called protection survey.

Rad: The unit of absorbed dose. The energy imparted to matter by ionizing radiation per unit mass of irradiated material at the place of interest. One rad equals 0.01 joules/kilogram of absorbing material.

Radiation: 1) The emission and propagation of radiant energy; for instance, the emission and propagation of electromagnetic waves or of sound and elastic waves. 2) The energy propagated through space or through a material medium; for example, energy in the form of alpha, beta, or gamma emissions from radioactive nuclei.

Radiation Area: Any area that is accessible to personnel in which there exists radiation at such levels that a major portion of the body could receive a dose in excess of 2 millirems in any 1 hour or a dose in excess of 100 millirems in any 7 consecutive days.

Radiation Background: See Background.

Radiation Leakage (Direct): All radiation coming from a source housing except the useful beam.

Radiation, Scattered: Radiation that has been deviated in direction during its passage through a substance. It may also have been modified by a decrease in energy.

Radiation, Stray: The sum of leakage and scattered radiation; also called "shine."

Radioactive Material: Any material or combination of materials that spontaneously emits ionizing radiation and has a specific activity in excess of 0.002 microcuries per gram of material [49 CFR 173.389(e)].

Radioactive Waste: Any material containing or contaminated with radionuclide at concentrations greater than the values that competent authorities would consider acceptable in materials suitable for uncontrolled use or release and for which there is no foreseen use. 
Radioactivity: The property of certain nuclides of spontaneously emitting particles or gamma radiation or of emitting $x$ radiation following orbital electron capture or of undergoing spontaneous fission. Often shortened to activity.

Radioactivity, Artificial: Man-made radioactivity produced by particle bombardment of electromagnetic irradiation.

Radioactivity, Induced: Radioactivity produced in a substance after bombardment with neutrons or other particles. The resulting radioactivity is "natural radioactivity" if formed by nuclear reactions occurring in nature and "artificial radioactivity" if caused by man.

Radioactivity, Natura 1: The property of radioactivity exhibited by more than 50 naturaliy occurring radionuclides.

Radiological Protection: Protection against the effects of internal and external human exposure to radiation and to radioactive materials.

Radionuclide Migration (Subsurface): The movement of radionuclides through porous and permeable strata due to subsurface water flow and/or by diffusion.

Rem: Acronym for roentgen equivalent man. A unit of dose equivalent in rems is numerically equal to the absorbed dose in rads multiplied by the quality factor, the distribution factor, and any other necessary modifying factors.

Remote Maintenance: Maintenance by remote means, i.e., the human is separated from the item being maintained by a shielding wall.

Repository: The site and all facilities where waste disposal takes place. Repository (Federal): A site owned and operated by the federal government for long-term storage or disposal of radioactive materials.

Roentgen: A unit of exposure to ionizing radiation. It is that amount of gamma or $x$-rays required to produce ions carrying one electrostatic unit of electrical charge (either positive or negative) in $1 \mathrm{~cm}^{3}$ of dry air under standard conditions. One roentgen equals $2.58 \times 10^{-4}$ coulomb per kilogram of air (see Exposure). 
Safe Storage: Those actions required to place and maintain a nuclear facility in such a condition that future risk to public safety from the facility is within acceptable bounds and that the facility can be safely stored for as long a time as desired.

Safety-Related: Structures, systems, and components, whose functions tend to prevent or mitigate the exceeding of safety limits as defined in Regulatory Guide 3.6 and set forth in Technical Specifications that are part of the Dperating License for a nuclear power plant. Quality Assurance Programs as defined in Appendix $B$ of 10 CFR 50 are not required for safety-related items except those defined also as "Q".

Scarfing: A removal technique used to decontaminate concrete mechanically by chipping, cutting, jackhammering, or blasting the surface layer(s) away.

Secondary Wastes: Forms and quantities of all wastes that result from treatment of primary wastes or effluents.

Shallow Land Burial: Disposal of radioactive waste by burial with at least $6 \mathrm{ft}$ of overburden with or without engineered barriers.

Shield: A body of material used to reduce the passage of particles or radiation. A shield may be designated according to what it is intended to absorb (as a gamma ray shield or neutron shield) or according to the kind of protection it is intended to give (as a background, biological, or thermal shield). It may be required for the safety of personnel, to reduce radiation enough to allow use of counting instruments for research, or for locating contamination or airborne radioactivity.

Short-Lived Radionuclides: Those radionuclides for which decay provides an adequate method of control (time periods of less than 100 years).

Shutdown: The time during which a site is not in productive operation.

Site: The geographic area upon which the facility is located that is subject to controlled public access by the facility licensee (includes the restricted area as designated in the NRC license). 
Solid Radioactive Waste: Material that is essentially solid and dry but may contain sorbed radioactive fluids in sufficiently small amounts as to be immobile.

Solidification: Conversion of radioactive wastes (gases or liquids) to dry, stable solids.

Surface Contamination (Radioactive): The deposition and attachment of radioactive material to a surface.

Surveillance: Those activities necessary to assure that the site remains in a safe condition, including periodic inspection and monitoring of the site, maintenance of barriers to access to radioactive materials left on the site, and prevention of activities on the site that might impair these barriers.

Survey: An evaluation of the radiation hazards incident to the production, use, release, disposal, or presence of radioactive materials or other sources of radiation under a specific set of conditions.

Transuranic Elements: Elements with atomic number ( 2 number) greater than 92. All transuranic elements are artificially produced and are radioactive.

Iransuranic Waste: Any waste material measured or assumed to contain more than a specified concentration (e.g., presently proposed as 10 nanocuries of transuranic elements per gram of waste) of transuranic elements.

Underground Disposal: Disposal of waste in a geological medium at any appropriate depth below the ground surface so as to interpose the medium as a protective barrier between man and the waste in such a manner as to prevent the disturbance and dispersal of the wastes by surface physical, biological, and human activities and to inhibit the escape of the waste into man's environment. The medium may also serve to protect and enhance the performance of any additional containment for the wastes and engineered barriers that may be provided. Furthermore, engineered features may be used to support or enhance the performance of the medium.

Underground Solid Waste Storage Area: Area within an exclusion area where radioactive solid waste is stored by burial. 
Waste Disposal: A condition where the waste itself is abandoned from the time it is put into the ground or elsewhere. The site is not necessarily abandoned but may be subject to monitoring and surveillance. There is no intention to recover the waste or attend to it in any way although its recovery may be technically possible.

Waste Storage: A condition where the waste itself is not abandoned; it is accessible for inspection, recovery, and repacking, etc., and there is an intention to carry out such work.

Waste, Radioactive: Equipment and materials (from nuclear operations) that are radioactive and for which there is no further use.

X-Ray: A penetrating form of electromagnetic radiation emitted either when the inner orbital electrons of an excited atom return to their normal state (characteristic $x$-rays) or when a metal target is bombarded with high-speed electrons. $X$-rays are always nonnuclear in origin, i.e., they originate external to the nucleus of the atom. 


\section{OISTRIBUTION}

No. of

Copies

OFFS I TE

\author{
A. A. Churm \\ DOE Patent Division \\ 9800 S. Cass Avenue \\ Argonne, IL 60439 \\ 255 U.S. Nuclear Regulatory \\ Commission \\ Division of Technical \\ Information and \\ Document Control \\ 7920 Norfolk Avenue \\ Bethesda, MD 20014 \\ 2 DOE Technical Information \\ Center \\ 10 D. E. Solberg \\ U.S. Nuclear Regulatory \\ Commission \\ Division of Safeguards, Fuel \\ Cycle \& Environmental Research \\ Mail Stop 1130-SS \\ Washington, D.C. 20555 \\ 10 F. J. Witt \\ U.S. Nuclear Regulatory \\ Commission \\ Division of Engineering \\ Chemical Engineering \\ Branch \\ Phillips Bldg, Mail Stop 234 \\ Washington, D.C. 20555 \\ T. Baer \\ Nuclear Engineering Co., Inc. \\ 9200 Shelbyille Road \\ Suite 526 \\ P.0. Box 7246 \\ Louisville, KY 40207
}

No. of

Copjes

M. L. Birch

Duke Power Company

P.0. Box 2178

Charlotte, NC 28242

R. Boyle

Dow Nuclear Services

Dow Chemical Company USA

Midland, MI 48640

L. Donovan

Dow Chemica 1 Company USA

2020 Dow Center

Midland, MI 48640

J. D. Cohen

Radiation \& Systems Analysis

Westinghouse Electric Corp.

P.0. 80x 355

Pittsburgh, PA 15230

P. T. Crinigan

Baltimore Gas and Electric Company

Calvert Cliffs Nuclear

Power Plant

Lusby, MD 20657

T. S. Drolet

Ontario Hydro

Nuclear Systems Department

700 University Avenue

Toronto, Ontario M5G $1 \times 6$

P. J. Gillis, Jr.

Stone \& Webster Engineering Co. Operations Services Division

245 Summer Street

Boston, MA 02107 
No, of

Copies

P. J. Grant

Babcock \& Wilcox

Research and Development

Division

Lynchburg, VA 24505

J. A. Knox

Halliburton Services

Chemical Research and

Development Department

Research Center

Duncan, OK 73533

W. S. Lange

Commonwealth Edison

Station Nuclear Engineering Dept.

One First National Plaza

P.0. Box 767

Chicago, IL 60690

A. P. Larrick

UNC/United Nuclear Industries

2900 George Washington Way

Richland, WA 99352

L. L. Nolan

Northern States Power

Montice lio Nuclear

Generating Plant

Montice 110, MN 55362

H. Oakley

Chem-Nuclear Corp.

Southeast/Southwest Operations

P.0. Box 726

Barnwe11, SC 29812

C. Ondash

Boston Edison Company

800 Boylston Street

Boston, MA 02199

W. S. Orser

Portland General Electric

Trojan Nuclear Plant

P.0. Box 439

Rainier, OR 97048
No. of

Copies

J. F. Remark

Quadrex Corporation

1700 Dell Avenue

Campbe 11, CA 95008

H. E. Rosenbach

Portland General Electric

Trojan Nuclear Plant

P.0. Box 439

Rainier, OR 97048

C. P. Ruiz

General Electric Company

Nuclear Energy Systems Division

Vallecitos Nuclear Center

P.0. Box 460

Pleasanton, CA 94566

W. B. Stewart

Ontario Hydro

Nuclear Systems Department

700 University Avenue

Toronto, Ontario M5G $1 \times 6$

J. N. Vance

Bechtel Power Corporation

P.0. $80 \times 1000$

Ann Arbor, MI 48106

J. L. White

Commonwealth Edison

Station Nuclear Engineering Dept.

One First National Plaza

P.0. Box 767

Chicago, IL 60690

T. R. Young

Combust ion Engineering, Inc.

Nuclear Power Systems

1000 Prospect Hill Road

Windsor, CT 06095 
No. of

Copies

ONSITE

50 Pacific Northwest Laboratory

T. D. Chikalla

R. L. Clark

R. L. Dillion

J. R. Divine (10)

S. K. Edler

L. G. Faust

L. K. Fetrow

V. F. FitzPatrick

W. A. Glass

C. R. Hann

G. A. Halseth

A. J. Haverfield

G. R. Hoenes

A. B. Johnson, Jr.

G. J. Konzek

R. P. Marsha11

L. F. Munson

J. L. Nelson (13)

L. 0. Perrigo

R. I. Smith

W. R. Wiley

E. M. Woodruff

Technical Information (5)

Publishing Coordination Y0(2) 


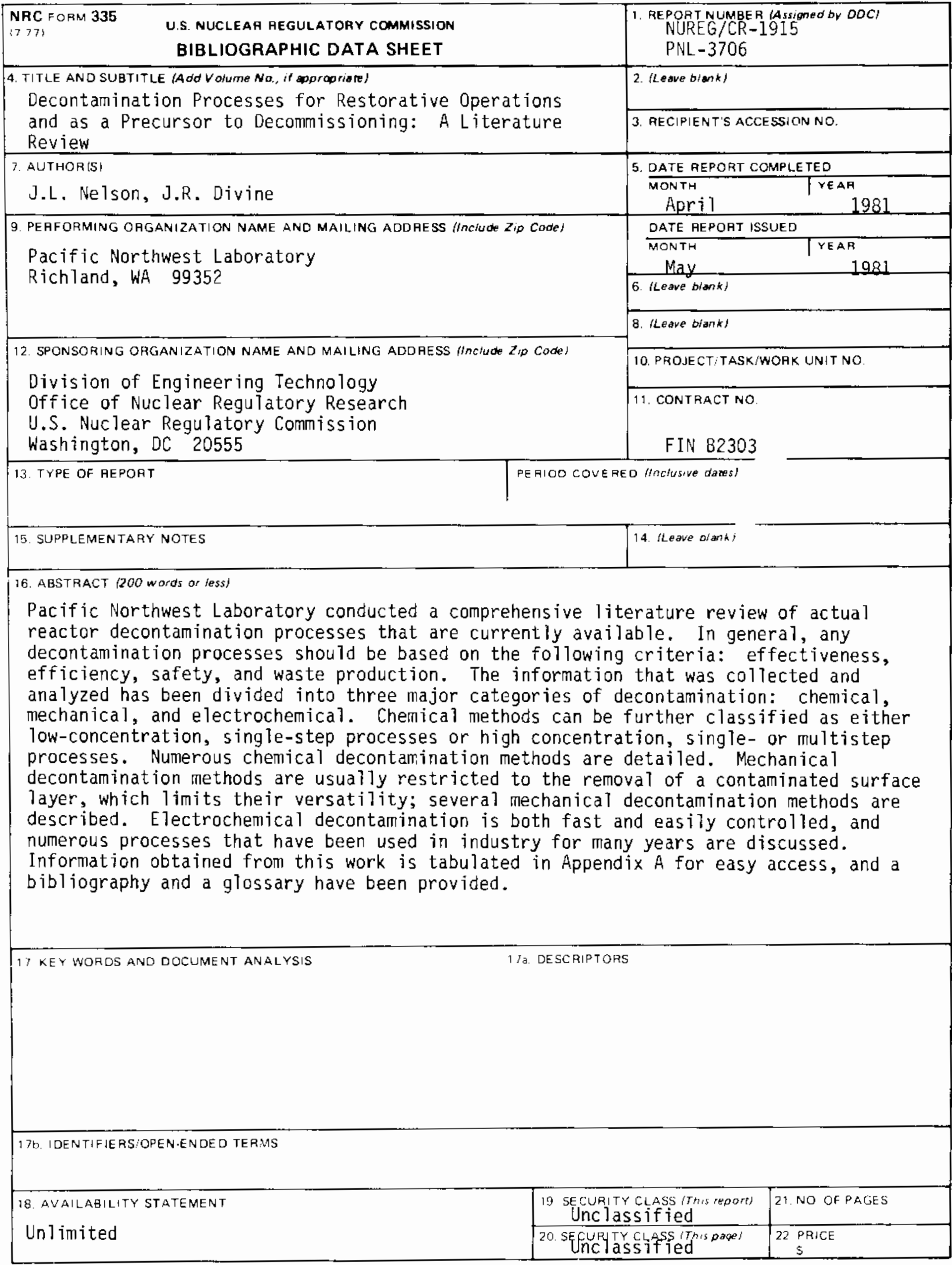


